Prepared in cooperation with Broward County, Florida

\title{
Hydrogeologic Framework and Salinity Distribution of the Floridan Aquifer System of Broward County, Florida
}

Scientific Investigations Report 2014-5029 
Cover. Aerial view of well drilling operations for G-2984, adjacent to the Hillsboro Canal in northern Broward County, Florida. Photo provided by Broward County Natural Resources Planning and Management Division. 


\section{Hydrogeologic Framework and Salinity Distribution of the Floridan Aquifer System of Broward County, Florida}

By Ronald S. Reese and Kevin J. Cunningham

Prepared in cooperation with Broward County, Florida

Scientific Investigations Report 2014-5029 


\section{U.S. Department of the Interior SALLY JEWELL, Secretary}

\section{U.S. Geological Survey Suzette M. Kimball, Director}

\section{U.S. Geological Survey, Reston, Virginia: 2014}

For more information on the USGS - the Federal source for science about the Earth, its natural and living resources, natural hazards, and the environment, visit http://www.usgs.gov or call 1-888-ASK-USGS.

For an overview of USGS information products, including maps, imagery, and publications, visit http://www.usgs.gov/pubprod

To order this and other USGS information products, visit http://store.usgs.gov

Any use of trade, firm, or product names is for descriptive purposes only and does not imply endorsement by the U.S. Government.

Although this information product, for the most part, is in the public domain, it also may contain copyrighted materials as noted in the text. Permission to reproduce copyrighted items must be secured from the copyright owner.

Suggested citation:

Reese, R.S., and Cunningham, Kevin, 2014, Hydrogeologic framework and salinity distribution of the Floridan aquifer system of Broward County, Florida: U.S. Geological Survey Scientific Investigations Report 2014-5029, 60 p., http://dx.doi.org/10.3133/sir20145029.

ISSN 2328-0328 (online) 


\section{Figures}

1. Map showing location of the study area in southeastern Florida, wells used in the study, and lines of hydrogeologic sections.......

2. Chart showing lithostratigraphic units in the study area, generalized lithology, and correlation to hydrogeologic units.

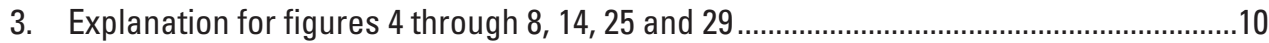

4. Borehole geophysical logs and lithologic data collected for well PB-1775 at site 16

5. Borehole geophysical logs and lithologic data collected for well G-2938 at site 6 .........13

6. Borehole geophysical logs and lithologic data collected for well CS-I2 at site 5 ...........14

7. Borehole geophysical logs and lithologic data collected for well G-2945 at site 23

8. Borehole geophysical logs, lithologic data, and depositional cycles and sequences for test corehole G-2984 at site 18 .

9. Map showing altitude of the upper contact surface of the Avon Park Formation ..........18

10. Map showing thickness of the upper Avon Park Formation ..........................................19

11. Map showing thickness of the lower Arcadia Formation.................................................21

12. Uninterpreted seismic-reflection profile acquired along the Hillsboro Canal and locations of wells PB-1766, PB-1775, and G-2984 projected onto the profile ...........26

13. Seismic-reflection profile displayed in figure 12 showing interpreted lithostratigraphic and sequence-stratigraphic boundaries, hydrostratigraphy, and seven seismic-sag structures..

14. Borehole geophysical data including fluid properties and flowmeter logs, lithology, hydrogeologic units, and flow zones for test corehole G-2984....

15. Map showing altitude of the upper surface of the Upper Floridan aquifer ......................31

16. Map showing thickness of the Upper Floridan aquifer ....................................................32

17. Map showing distribution of transmissivity in the Upper Floridan aquifer ........................33

18. Map showing altitude of the upper boundary of the Avon Park permeable zone ............35

19. Map showing thickness of the Avon Park permeable zone ...........................................36

20. Map showing distribution of transmissivity of the Avon Park permeable zone...............37

21. Borehole geophysical log data for test corehole G-2984, from 955 to $968 \mathrm{ft}$ bls, including optical and acoustic images, flowmeter and fluid properties, flow zones, and relation to high frequency depositional cycles.

22. Borehole geophysical log data for test corehole G-2984, from 1,102 to $1,115 \mathrm{ft}$ bls, including optical and acoustic images, flowmeter and fluid properties, flow zones, and relation to high frequency depositional cycles.....

23. Photographs showing microscopic images of G-2984 at 1,109.45 ft bls

24. Borehole geophysical log data for test corehole G-2984, from 1,165 to 1,178 ft bls, including optical and acoustic image, flowmeter and fluid properties, flow zones, and relation to high frequency depositional cycles.

25. Borehole geophysical log data, including fluid properties and flowmeter log data, lithology, hydrogeologic units, and flow zones, for monitoring well G-2940 at site 6 , from 900 to $1,220 \mathrm{ft}$ bls.

26. Borehole geophysical log data for well G-2940, from 1,024 to $1,038 \mathrm{ft}$ bls, including optical image, flowmeter and fluid properties, and flow zones.

27. Map showing distribution of salinity as dissolved-solids concentration in the Upper Floridan aquifer. 
28. Map showing distribution of salinity as dissolved-solids concentration in the Avon Park permeable zone.....

29. Water-quality data, resistivity geophysical log data, salinity zones, and lithostratigraphic and hydrogeologic units for wells at site 5 .

30. Map showing greatest depth of groundwater with dissolved solids concentration of less than or equal to $10,000 \mathrm{mg} / \mathrm{l}$.

31. Schematic diagram showing perched zone of elevated salinity in the Upper Floridan aquifer in the west central part of the study area .51

32. Graph showing relation between transmissivity and salinity in the Upper

Floridan aquifer

\section{Tables}

1. Lithostratigraphic and geophysical-log units identified or defined in the study ...............9

2. Nomenclature of stratigraphic cycle hierarchies and order of cyclicity.........................20

3. Avon Park Formation lithofacies in well G-2984 ..............................................................23

4. Horizontal hydraulic conductivity values for major permeable zones and semiconfining units based on data from aquifer and packer tests in the study area

\section{Appendix Tables}

[Appendix tables 1-1 to 1-8 available for download at $h t t p: / / d x$.doi.org/10.3133/sir20145029 in MS Excel format]

1-1. Well identifiers, locations, and construction information for all wells used in the study..... link

1-2. Sources for well data compiled for this study .......................................................... link

1-3. Types of data compiled for wells used in study........................................................ link

1-4. Stratigraphic boundaries identified from well data in the study area.......................... link

1-5. Hydrogeologic boundaries identified from well data in the study area ........................ link

1-6. Hydraulic well tests descriptions and results.............................................................. link

1-7. Water-quality data collected from the Floridan aquifer system ................................... link

1-8. Salinity boundary depths determined in this study.................................................... link 


\section{Conversion Factors}

Inch/Pound to SI and cubic feet to gallons

\begin{tabular}{|c|c|c|}
\hline Multiply & By & To obtain \\
\hline \multicolumn{3}{|c|}{ Length } \\
\hline inch (in.) & 2.54 & centimeter $(\mathrm{cm})$ \\
\hline inch (in.) & 25.4 & millimeter (mm) \\
\hline foot $(\mathrm{ft})$ & 0.3048 & meter $(\mathrm{m})$ \\
\hline mile (mi) & 1.609 & kilometer $(\mathrm{km})$ \\
\hline \multicolumn{3}{|c|}{ Volume } \\
\hline cubic foot $\left(\mathrm{ft}^{3}\right)$ & 7.479 & gallons (gal) \\
\hline \multicolumn{3}{|c|}{ Flow rate } \\
\hline gallon per minute (gal/min) & 0.06309 & liter per second $(\mathrm{L} / \mathrm{s})$ \\
\hline \multicolumn{3}{|c|}{ Hydraulic conductivity } \\
\hline foot per second (ft/s) & 0.3048 & meter per second $(\mathrm{m} / \mathrm{s})$ \\
\hline foot per day (ft/d) & 0.3048 & meter per day $(\mathrm{m} / \mathrm{d})$ \\
\hline foot per day (ft/d) & 7.479 & gallon per day per feet squared $\left(\mathrm{gal} / \mathrm{d} / \mathrm{ft}^{2}\right)$ \\
\hline \multicolumn{3}{|c|}{ Transmissivity* $^{*}$} \\
\hline foot squared per day $\left(\mathrm{ft}^{2} / \mathrm{d}\right)$ & 0.09290 & meter squared per day $\left(\mathrm{m}^{2} / \mathrm{d}\right)$ \\
\hline foot squared per day $\left(\mathrm{ft}^{2} / \mathrm{d}\right)$ & 7.479 & gallon per day per foot (gal/d/ft) \\
\hline \multicolumn{3}{|c|}{ Leakance } \\
\hline foot per day per foot $[(\mathrm{ft} / \mathrm{d}) / \mathrm{ft}]$ & 1 & meter per day per meter \\
\hline foot per day per foot $[(\mathrm{ft} / \mathrm{d}) / \mathrm{ft}]$ & 7.479 & gallon per day per cubic foot $\left(\mathrm{gal} / \mathrm{d} / \mathrm{ft}^{3}\right)$ \\
\hline
\end{tabular}

Temperature in degrees Celsius $\left({ }^{\circ} \mathrm{C}\right)$ may be converted to degrees Fahrenheit ( $\left.{ }^{\circ} \mathrm{F}\right)$ as follows:

$$
{ }^{\circ} \mathrm{F}=\left(1.8 x^{\circ} \mathrm{C}\right)+32
$$

Temperature in degrees Fahrenheit $\left({ }^{\circ} \mathrm{F}\right)$ may be converted to degrees Celsius $\left({ }^{\circ} \mathrm{C}\right)$ as follows:

$$
{ }^{\circ} \mathrm{C}=\left({ }^{\circ} \mathrm{F}-32\right) / 1.8
$$

Vertical coordinate information is referenced to the National Geodetic Vertical Datum of 1929 (NGVD 29).

Horizontal coordinate information is referenced to the North American Datum of 1927 (NAD 27) or North American Datum of 1983 (NAD 83).

Altitude, as used in this report, refers to distance above the vertical datum.

*Transmissivity: The standard unit for transmissivity is cubic foot per day per square foot times foot of aquifer thickness [( $\left.\left.\mathrm{ft}^{3} / \mathrm{d}\right) / \mathrm{ft}^{2}\right] \mathrm{ft}$. In this report, the mathematically reduced form, foot squared per day $\left(\mathrm{ft}^{2} / \mathrm{d}\right)$, is used for convenience.

Specific conductance is given in microsiemens per centimeter at 25 degrees Celsius $\left(\mu \mathrm{S} / \mathrm{cm}\right.$ at $\left.25^{\circ} \mathrm{C}\right)$.

Concentrations of chemical constituents in water are given either in milligrams per liter (mg/L) or micrograms per liter $(\mu \mathrm{g} / \mathrm{L})$ 


\section{Abbreviations}

$\begin{array}{ll}\text { bls } & \text { below land surface } \\ \text { ABI } & \text { acoustic borehole image (log) } \\ \text { AIV } & \text { average interval velocity } \\ \text { ASR } & \text { aquifer storage and recovery } \\ \text { DGPS } & \text { differential global positioning system } \\ \text { GR } & \text { gamma-ray } \\ \text { GWSI } & \text { Groundwater Site Inventory (database) } \\ \text { HFC } & \text { high-frequency cycle } \\ \text { kHz } & \text { kilohertz } \\ \text { LFA } & \text { Lower Floridan aquifer } \\ \mu \text { sec/ft } & \text { microsecond per foot } \\ \text { MAP } & \text { middle Avon Park } \\ \text { OBI } & \text { optical borehole image (log) } \\ \text { ohm-m } & \text { ohm-meter } \\ \text { RASA } & \text { Regional Aquifer System Analysis } \\ \text { SFWMD } & \text { South Florida Water Management District } \\ \triangle \mathrm{t} & \text { sonic borehole geophysical log interval transit time, } \\ \text { USDW } & \text { in microseconds per foot } \\ \text { USGS } & \text { underground source of drinking water } \\ & \text { U.S. Geological Survey }\end{array}$





\title{
Hydrogeologic Framework and Salinity Distribution of the Floridan Aquifer System of Broward County, Florida
}

\author{
By Ronald S. Reese and Kevin J. Cunningham
}

\section{Abstract}

Concerns about water-level decline and seawater intrusion in the surficial Biscayne aquifer, currently the principal source of water supply to Broward County, prompted a study to refine the hydrogeologic framework of the underlying Floridan aquifer system to evaluate its potential as an alternative source of supply. This report presents cross sections that illustrate the stratigraphy and hydrogeology in eastern Broward County; maps of the upper surfaces and thicknesses of several geologic formations or units within the Floridan aquifer system; and maps of two of the potentially productive water-bearing zones within the system, the Upper Floridan aquifer and the Avon Park permeable zone.

An analysis of data on rock depositional textures, associated pore networks, and flow zones in the Floridan aquifer system shows that groundwater moves through the system in two ways. These data support a conceptual, dualporosity model of the system wherein groundwater moves either as concentrated flow in discrete, thin bedding-plane vugs or zones of vuggy megaporosity, or as diffuse flow through rocks with primarily interparticle and moldic-particle porosity. Because considerable exchange of groundwater may occur between the zones of vuggy and matrix-dominated porosity, understanding the distribution of that porosity and flow zone types is important to evaluating the suitability of the several units within the Floridan aquifer system for managing the water through practices such as aquifer storage and recovery (ASR).

The salinity of the water in the Floridan aquifer system is highest in the central part of the study area, and lower toward the north and south. Although salinity generally increases with depth, in the western part of the study area a zone of relatively high saline water is perched above water of lower salinity in the underlying Avon Park permeable zone. Overall, the areas of highest salinity in the aquifer system coincide with those with the lowest estimated transmissivity, so that the occurrence of perched saline water in the system may be the consequence of incompletely flushed connate water or intruded seawater.
A seismic reflection profile along the Hillsboro Canal, at the northern edge of the study area, shows seven seismic-sag structures that are interpreted as downward deformation of overlying strata into collapsed deep cave systems. These structures may compromise the integrity of the confinement created by the underlying strata by allowing upconing of saline water from depth, which has implications for successful application of ASR and use of the Floridan aquifer system as an alternative water supply.

\section{Introduction}

The Biscayne aquifer is shallow and prolific, and has provided most of the water supply in eastern Broward County, Florida (fig. 1), during the last century. Concerns about water-level declines and saltwater intrusion in the Biscayne aquifer have prompted limits on municipal withdrawals and on new water-supply well-field permits. Consequently, the county is examining the potential for the use of the Floridan aquifer system as an alternative water supply, either directly, by pumping and treating water from wells completed in the aquifers, or indirectly, by aquifer storage and recovery (ASR).

The Floridan aquifer system has not been used historically for water supply in southeastern Florida because of elevated groundwater salinity (Sprinkle, 1989). Brackish water in the aquifer system may be treated for public supply by using reverse-osmosis desalination technologies, or by mixing it with freshwater from the surficial aquifer system. Knowledge of the distribution of salinity and hydraulic properties within the aquifer system, such as hydraulic conductivity and degree of confinement, may improve the predictability of finding an alternative water supply with low salinity and high yield.

Aquifer storage and recovery has been implemented in the Floridan aquifer system for water-supply storage in Broward County and other counties in southeastern Florida with varying degrees of success (Reese and AlvarezZarikian, 2007). The objective of ASR is to increase available 


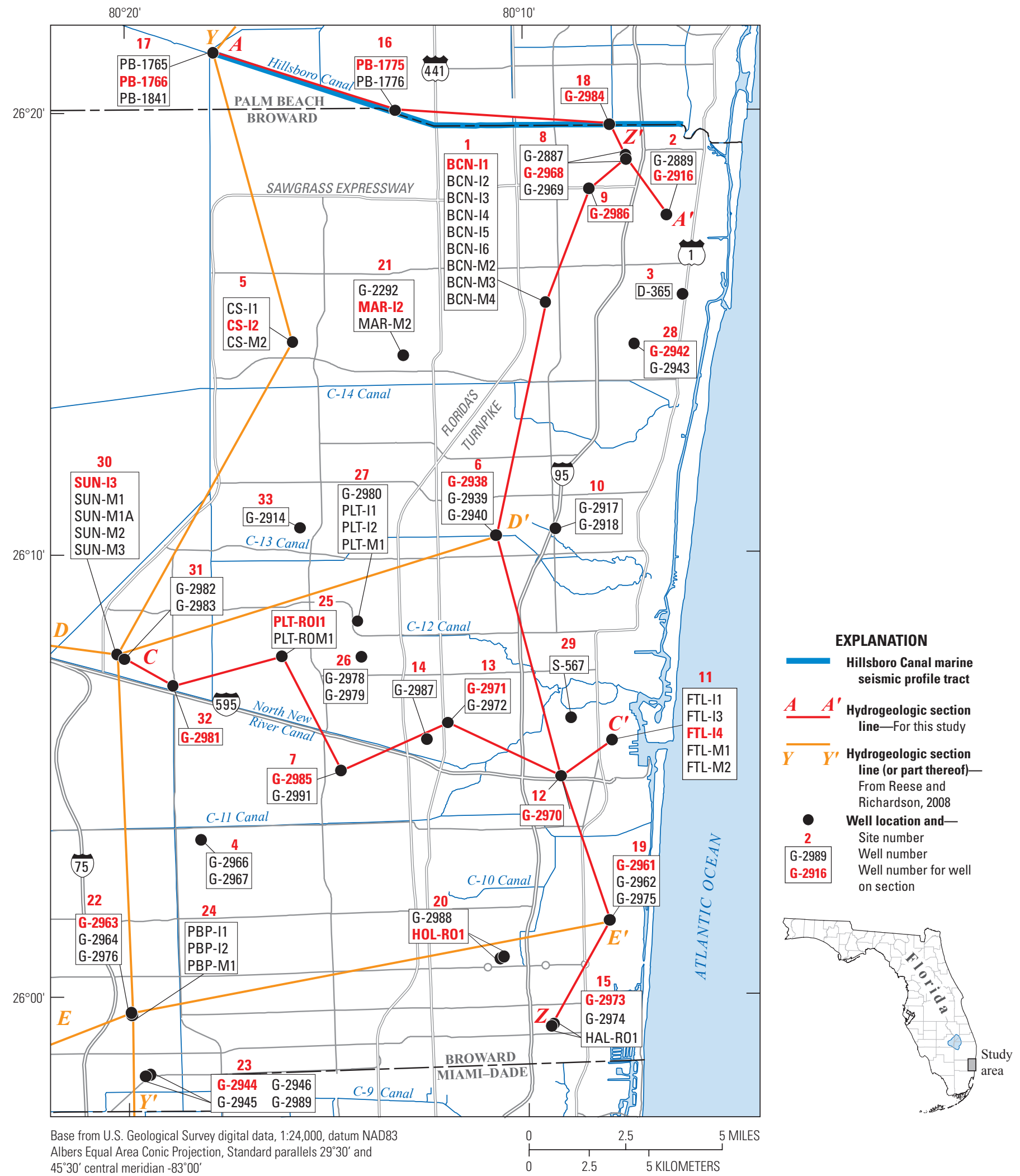

Figure 1. Location of the study area in southeastern Florida, wells used in the study, and lines of hydrogeologic sections. Site numbers and names and types of wells are provided in appendix table 1-1. 
supply by diverting relatively fresher water to displace native, brackish groundwater in the Upper Floridan aquifer of the Floridan aquifer system for subsequent recovery. In Palm Beach County, the cumulative recovery efficiency at the Boynton Beach East Water Treatment Plant, about 15 miles (mi) north of Broward County, has reached more than 60 percent, which is considered a successful level of recovery efficiency. In contrast, cycle testing at three ASR projects in Broward County has not demonstrated cumulative recovery efficiencies greater than about 30 percent as of the end of 2004. The success of ASR is largely dependent on (1) the presence of an optimal range in the transmissivity of the storage zone and an optimal distribution of hydraulic conductivity of the aquifer materials; (2) geologic structure that substantially limits or prevents migration of injected freshwater away from an ASR well or storage zone, both horizontally and vertically; and (3) low salinity in the aquifer. High salinity groundwater (water with a dissolved-solids concentration of about 5,000 milligrams per liter $[\mathrm{mg} / \mathrm{L}]$ or greater) in the Floridan aquifer system may adversely affect the utility of ASR, because the resulting mix of injected water with the brackish-to-saline groundwater may result in recovered water that is too saline to be used for public supply. The ability to predict the physical properties of an aquifer that will be conducive to ASR requires a refined hydrogeologic framework; conversely, poor definition of the hydrogeologic framework increases the risk for planning and design failures.

A sequence-stratigraphic analysis can be used to refine the hydrogeologic framework of the Floridan aquifer system and delineate the spatial distribution and hydraulic connectivity of permeable zones. Carbonate sequence stratigraphy differs from traditional lithostratigraphy in that unconformities or their relative conformities related to relative fall or rise in sea level are correlated (Schlager, 2005). Because these surfaces are present at the top and bottom of depositional cycles and sequences, and are related to widespread physical events, they are assumed to have time significance. Correlation of these surfaces provides a more accurate method of correlation of rock units between the surfaces than lithostratigraphic analyses alone. The recognition of the vertical arrangement of lithostratigraphic successions and stratal patterns bounded by these surfaces also helps to correlate flow zones and confining units, and to estimate the thickness, porosity, and permeability of the hydrologic units.

To provide information about the Floridan aquifer system that would help water-resource managers evaluate it as an alternative water supply, for imminent use with reverseosmosis desalination or blending, and for storage with ASR, the U.S. Geological Survey (USGS), in cooperation with Broward County, initiated a study to refine the delineation of the hydrogeologic framework of the Floridan aquifer system in Broward County. As part of this study, a test hole was continuously cored penetrating about 350 feet (ft) of the uppermost Floridan aquifer in northeastern Broward County along Hillsboro Canal. Data collected from this test corehole were interpreted using both a traditional lithostratigraphic approach and, over the deeper intervals, a sequence-stratigraphic approach, and correlated with existing borehole data across the eastern part of the county. Seismic-reflection data collected along the Hillsboro Canal were used to illustrate the hydrogeologic framework in two dimensions, assist with the sequence-stratigraphic analysis, and identify structural features that intersect hydrogeologic units and provide potential pathways for vertical groundwater movement in the Floridan aquifer system. Water-quality data from the test borehole provided information about the distribution of salinity in the aquifer system. Information in this report can be used by water-resource managers to identify areas in eastern Broward County that would be favorable for water-supply development in the Floridan aquifer system.

\section{Purpose and Scope}

The purpose of this report is to (1) refine the hydrogeologic framework of the Floridan aquifer system from the lower Avon Park Formation to the upper surface of the aquifer system in eastern Broward County, using borehole geophysical log data and, where appropriate, integrating those data with lithostratigraphic and sequence-stratigraphic analyses; (2) evaluate hydraulic properties of major permeable units; and (3) characterize salinity distribution of major permeable units. The study area encompasses the developed part of Broward County, east of the Everglades, and an adjacent part of southeastern Palm Beach County (fig. 1). More specifically, the report (1) distinguishes the major permeable zones and semiconfining units of part of the Floridan aquifer system, and delineates their configuration, thickness, and extent; (2) estimates hydraulic properties of these units; (3) describes the distribution of salinity within these units; and (4) suggests hypotheses to explain the distributions of hydraulic properties and salinity.

Borehole geophysical data, lithologic information, hydraulic property data, and water-quality data collected in other studies and used in this analysis are included herein. This report includes three hydrogeologic cross sections extending across the county, maps of subsurface altitudes and thicknesses of major permeable zones in the Floridan aquifer system, maps of transmissivity and salinity of major permeable zones, and a map of the greatest depth of brackish water within the Floridan aquifer system. Additionally, this report presents data collected from the cored test hole (G-2984) in northeastern Broward County, and 14.3 mi of high-resolution, multichannel, water-based seismic-reflection data acquired along the Hillsboro Canal (fig. 1).

\section{Hydrogeologic Setting}

The Floridan aquifer system is the deepest of three principal hydrogeologic units present in the study area, and is overlain by the shallow surficial aquifer system, and the intermediate confining unit, which separates the system from 


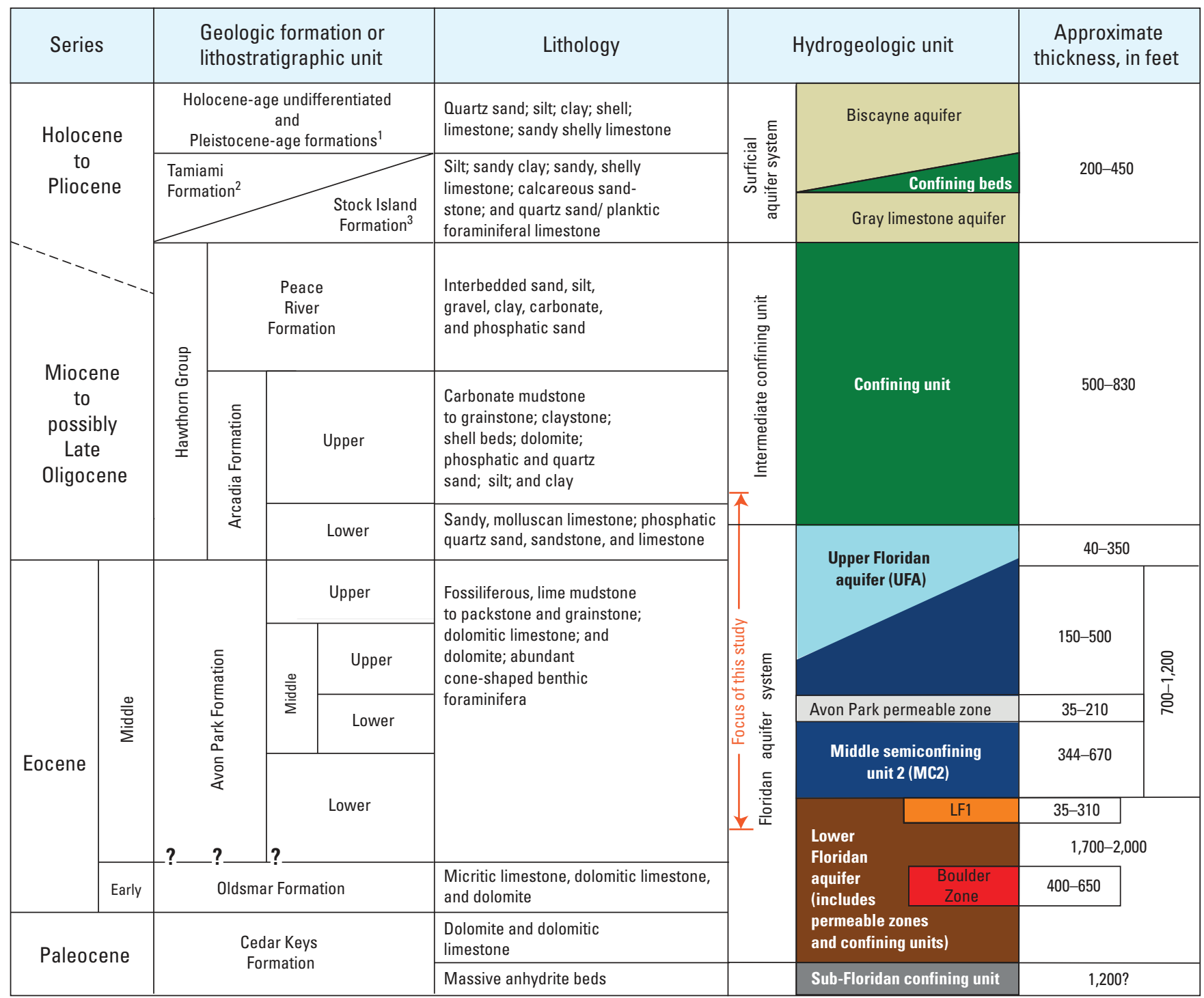

${ }^{1}$ Pleistocene-age formations in southeastern Florida (Pamlico Sand, Miami Limestone, Anastasia Formation, Fort Thompson Format

${ }^{2}$ Tamiami Formation (Pinecrest Sand Member, Ochopee Limestone Member).

${ }^{3}$ Stock Island Formation, after Cunningham and others, 1998.
EXPLANATION

LF1 Uppermost major permeable zone of the Lower Floridan aquifer

Figure 2. Lithostratigraphic units in the study area, generalized lithology, and correlation to hydrogeologic units. Subdivisions of the Arcadia and Avon Park Formations are defined in this study and are informal.

the surficial aquifer system (fig. 2). The heavily-used Biscayne aquifer composes a part of the surficial aquifer system. The Floridan aquifer system in South Florida includes a thick sequence of highly permeable, carbonate strata of Tertiary age, and is part of the Florida Platform (Hine, 2013). The Floridan aquifer system has generally been divided into the Upper Floridan aquifer, the underlying middle confining unit or middle semi-confining units, and the Lower Floridan aquifer (LFA) (Miller, 1986). Locally, permeable units have been identified within the confining unit between the Upper Floridan aquifer and the Lower Floridan aquifer, specifically, the Avon Park permeable zone (Reese and Richardson, 2008), and below the middle confining unit, the uppermost permeable zone of the Lower Floridan aquifer.

\section{Previous Investigations}

A comprehensive regional investigation of the Floridan aquifer system hydrogeology for Florida and parts of Georgia, Alabama and South Carolina was conducted in the 1980s as part of the USGS Regional Aquifer System Analysis (RASA) Program (USGS Professional Paper 1403 series reports). The hydrogeologic framework of the Floridan aquifer system for the entire RASA study area was described by Miller (1986). The groundwater hydraulics, regional flow, and groundwater development of the aquifer system were described for the same region by Bush and Johnston (1988), and Meyer (1989) described the hydrogeology and delineated groundwater movement patterns in southern Florida. 
More recent hydrogeologic studies of the Floridan aquifer system in southeastern Florida include those of the hydrogeology and distribution of salinity within the upper part of the Floridan aquifer system in Miami-Dade and Broward Counties (Reese, 1994), Palm Beach County (Reese and Memberg, 2000), and in Martin and St. Lucie Counties (Reese, 2004). Reese and Richardson (2008) synthesized previous studies on the Floridan aquifer system in central and southern Florida and introduced a revised regional hydrogeologic framework, linking hydrogeologic nomenclature and previously mapped hydrogeologic units between central and southern Florida and between the western and eastern coastal areas.

Test-well drilling and hydrogeologic investigations of the Floridan aquifer system have been conducted by both the USGS and South Florida Water Management District (SFWMD) in Broward County and southern Palm Beach County since the 1980s. Two sites with multiple wells drilled by SFWMD are within the current study area (Bennett and others, 2001; Lukasiewicz, 2003). The USGS drilled and completed a deep well in the Floridan aquifer system in westernmost Broward County and correlated formation boundaries with water-bearing zones in the aquifer system (Meyer, 1988).

Sequence-stratigraphic analyses have been made in previous studies on the basis of data collected from test coreholes completed in the Floridan aquifer system in southern Florida. Cunningham and others (1998) characterized the lithostratigraphy and sequence stratigraphy of the Suwannee Limestone and Arcadia Formation south of the study area in southern Miami-Dade County and in the Florida Keys. Guertin and others (2000) subsequently used chronostratigraphic methods to determine the duration of major sequence boundaries at the upper boundaries of the Suwannee Limestone and Arcadia Formation in southern Florida. Hammes (1992) defined the sequence stratigraphy and sedimentology of the Suwannee limestone (referred to as Suwannee Formation in Hammes, 1992) in southwestern Florida. Missimer (2002) identified lithofacies, sequences, and supersequences that compose the Arcadia Formation in southwestern Florida. Ward and others (2003) analyzed the sequence stratigraphy of the upper part of the Avon Park Formation and Ocala Limestone using core description and other data (including digital optical borehole imaging) collected from a well north of the study area in south-central Florida (Highlands County). Budd and Vacher (2004) defined depositional cycles in the Avon Park Formation in a well in west-central Florida. Maliva and others (2009) used a micro-resistivity imaging log to identify a stacked, cyclic depositional pattern in the Avon Park Formation in a test well in south-central Florida (Glades County). An inventory and review of existing ASR wells utilizing the Floridan aquifer system of southern Florida was conducted by Reese (2002), and Reese and Alvarez-Zarikian (2007) made a more complete comparative analysis of aquifer system ASR wells in southern Florida that included ASR site performance and hydrogeologic framework definition. Ward and others (2003) showed that integrating carbonate sequence stratigraphy and hydraulic data can be a valuable approach for evaluating areas suitable for ASR in southern Florida.

\section{Methods of Investigation}

Data collected for this study and existing data from the study area were used to construct lithostratigraphic and sequence-stratigraphic frameworks for the upper part of the Upper Floridan aquifer, and a hydrogeologic framework for the upper part of the Floridan aquifer system. This information included well data from throughout the study area and reflection seismic data collected along Hillsboro canal.

\section{Collection and Compilation of Well Data}

Well data used in the analyses in the study and described or included in this report include data collected from previously drilled wells and from the Upper Floridan aquifer test corehole G-2984 (site 18, fig. 1). Previously collected data were compiled from well construction reports for aquifer system wells drilled and completed for a variety of purposes, including wastewater injection, water supply, ASR, and hydraulic testing. Information from 84 wells at 33 sites was used in this study (fig. 1; appendix table 1-1). Well identification, location, and construction information are stored in the USGS Groundwater Site Inventory (GWSI) database, and can be accessed using the USGS local well identifier (appendix table 1-1), or in well construction reports (appendix table 1-2). Data collected and compiled for sites in the study area include lithologic descriptions, borehole geophysical data and images, hydraulic properties, and water-quality data (appendix table 1-3).

Test corehole G-2984 was continuously cored from land surface into the Upper Floridan aquifer to a total depth of 1,308 ft below land surface (bls) within the uppermost part of the Avon Park Formation. The core samples were examined for lithology, color, grain size, texture, porosity, depositional features, exposure surfaces, bedding thickness, and fossil content. Optical and acoustic images of the borehole were collected, and can be used to observe geologic or hydrologic features from sections of missing core, or can be used to calibrate depths of core and observed features. Lithostratigraphy and sequence stratigraphy were delineated using information from G-2984 core samples, optical borehole images (OBIs), and acoustic borehole images (ABIs). Other borehole geophysical data collected include: natural gammaray activity (GR), caliper, induction formation resistivity (rock plus groundwater), spontaneous potential, single point resistance, sonic, flowmeter, and borehole fluid conductivity and temperature. These geophysical data provide vertical logs or records of the rock or fluid properties or both within the borehole. Recognizable patterns in the borehole geophysical logs can be used to identify specific geologic or hydrogeologic units and contacts. Borehole sonic data record changes in interval sonic wave transit time (sonic $\Delta \mathrm{t}$ ) and can provide information on relative porosity. Spinner flowmeter data are used to locate intervals (flow zones) in which groundwater is flowing into the borehole or borehole fluid is flowing out of 
Hydrogeologic Framework and Salinity Distribution of the Floridan Aquifer System of Broward County, Florida

the borehole. When combined with other borehole geophysical data, such as OBI images, it is possible to estimate the relative contribution of each flow zone to total borehole fluid discharge from a well.

Borehole geophysical data were also acquired as part of this study in three previously drilled wells (G-2939 and G-2940 at site 6 and G-2916 at site 2; fig. 1); these data include caliper, spinner flowmeter, borehole fluid conductivity and temperature, and induction resistivity logs; and optical borehole images.

Borehole geophysical data from previously drilled wells, collected by commercial logging companies, were used to guide well-to-well correlation and identification of major water-bearing units. These data include gamma ray, caliper, spontaneous potential, dual-induction and shallow formation resistivity, sonic $\Delta \mathrm{t}$, borehole fluid properties including temperature and conductivity, and spinner flowmeter measurements. In addition, existing borehole image data, also collected by commercial logging companies, including acoustic televiewer and formation microresistivity images, were used to assist in the identification of stratigraphic boundaries.

Additional lithologic data from wells in the study area were compiled from Florida Geological Survey reports (Florida Geological Survey, 2012), and SFWMD and consultants' well-construction reports that are available online at the SFWMD hydrogeologic data archive website (http://mytest. sfwmd.gov/dbhydroplsql/show_dbkey_info.main_menu) called DBHYDRO (appendix table 1-2). These data were reviewed on an individual well basis to determine if they provided sufficient detail and were used in this study only to help guide stratigraphic interpretations.

Salinity distribution in the Floridan aquifer system was characterized on the basis of analyses of existing waterquality data (appendix table 1-3). Most of these data were compiled from construction reports, and some data were collected as part of previous studies by the USGS. These data include specific conductance, and chloride, sulfate, and dissolved-solids concentration.

\section{Delineation of Lithostratigraphic, Sequence- Stratigraphic, and Hydrogeologic Frameworks}

The correlation of lithostratigraphic, sequence-stratigraphic and hydrogeologic frameworks across Broward County provides information needed to identify areas in the eastern part of the county that would be favorable for the development of a water supply from the Floridan aquifer system. The lithostratigraphic framework describes the 3-dimensional distribution of lithostratigraphic units, or boundaries between lithostratigraphic units, as identified by distinct and pervasive spatial changes in lithologic characteristics. Lithology is the description of rocks on the basis of such characteristics as texture, mineralogic composition, and grain size (Neuendorf and others, 2005). Lithostratigraphic boundaries in the upper part of the Upper Floridan aquifer were identified by distinct and pervasive vertical changes in lithology observed in core and cuttings samples collected in eastern Broward County - in test corehole G-2984, well PB-1766, and well G-2968 (fig. 1). For the intervals in the upper part of the Upper Floridan aquifer for which core was available, these lithostratigraphic boundaries correlate with characteristic patterns in borehole geophysical data, such as GR or sonic $\Delta t \operatorname{logs}$, and the boundaries were delineated throughout the study area using these data.

The lithostratigraphic framework was extended deeper in the Floridan aquifer system into a stratigraphic framework using geophysical-log marker horizons, and these marker horizons were also delineated throughout the study area. GR and sonic $\Delta \mathrm{t}$ data were used in well-to-well correlation. A major reason for the reliance on geophysical-log marker horizons is the limited vertical coverage of lithology based on core samples for the intermediate confining unit and Floridan aquifer system. Also, for many wells, existing descriptions of drill cuttings were not considered reliable or were of insufficient detail to be used as input into a lithostratigraphic framework. The geophysical-log marker horizons are the most robust element used in the delineation of the three frameworks throughout the study area.

The sequence-stratigraphic framework describes the 3-dimensional distribution of depositional cycles. In wells for which only 1-dimensional data are available, depositional cycles are identified by the vertical arrangement of varying lithologies (defined by sedimentary particle types, depositional textures, and bedding style), and are bound by upper and lower surfaces that represent an abrupt upward increase in paleo-water depth. In lithologic logs of wells, the depositional cycle is the fundamental and smallest set of vertical lithologic variation that occurs during a single cycle of relative sea-level rise and fall. Depositional cycles are classified from lower- to higher-order (larger to smaller in scale) (as in Kerans and Tinker, 1997, fig. 1.11). In general, lower order depositional cycles may correlate over a regional scale. Depositional cycles in the uppermost part of the Upper Floridan aquifer were identified by examination of core samples and borehole image data from the test corehole $\mathrm{G}-2984$. A preliminary sequencestratigraphic framework was developed, and extended throughout the study area based primarily on correlation of geophysical-log marker horizons, but including, where available, lithologic descriptions, OBIs, ABIs, acoustic televiewer data, and formation microresistivity image data.

The hydrogeologic framework describes the 3-dimensional distribution of hydrogeologic units, notably aquifers and confining units, as identified by distinct and pervasive differences in hydrologic characteristics, such as permeability and porosity. Boundaries between hydrogeologic units in the Floridan aquifer system were delineated using borehole geophysical data - principally flowmeter measurements, and fluid-temperature and conductivity data, and borehole images. Other contributing data include hydraulic test data such as that from aquifer and packer tests, lithologic descriptions, drilling characteristics, and zone-specific 
water-quality data (appendix table 1-3). Hydrogeologic units may comprise multiple flow zones. In many cases, flow zones can be identified by abrupt and substantial vertical changes in borehole fluid flow rates or fluid temperature and conductivity measurements, or both. Where hydraulic test data or borehole geophysical flowmeter and fluid properties data were not available, approximate determinations of hydrologic unit boundaries were made based on correlation of other data, including lithologic descriptions and other geophysical data that included formation resistivity, sonic $\Delta t$ or density (both related to formation porosity), GR, caliper, and spontaneous potential data.

\section{Marine Seismic Acquisition, Processing, and Interpretation}

In 2010, about $14 \mathrm{mi}$ of digital, high-resolution, multichannel, marine seismic-reflection data were acquired (from a shallow-draft boat) by Walker Marine Geophysical Company along the Hillsboro Canal at the border between Broward and Palm Beach Counties (fig. 1).Water depths in the canal ranged from about 5 to $12 \mathrm{ft}$. The seismic-reflection survey was completed using a MARDAQ25 digital acquisition and processing system, an air-gun source array, and 24-channel hydrophone streamer. Digital sampling rate was 10 kilohertz (kHz), shot spacing between 19.7 and $26.2 \mathrm{ft}$, and range of the recording window from 0 to 1.0 second. Real-time navigational positions were collected with a Trimble differential global positioning system (DGPS). Data were recorded on a proprietary 24-bit parallel system in SEGY format. Post-cruise data processing was conducted by Velseis Pty. Ltd. and included true amplitude and migrated stacks to produce a seismic profile in SEGY format.

Geophysical data, borehole images, and lithologic descriptions from the test corehole G-2984, and boreholes PB-1766 and PB-1775 (fig. 1) were used to link the seismic reflection stratigraphy on the seismic-reflection profile to lithostratigraphic and hydrogeologic units identified in the well data. Some of the depositional sequences identified in test corehole G-2984 were identified on the seismic profile. Preliminary description and interpretation of seismicreflection configuration patterns are based on comparison to examples in Mitchum and others (1977).

\section{Stratigraphic Framework}

The Floridan aquifer system in the study area is a thick sequence of predominantly carbonate rocks that includes, in ascending order, the upper part of the Cedar Keys Formation of Paleocene age, the Oldsmar Formation of early Eocene age, the Avon Park Formation of middle Eocene age, and the lower part of the Arcadia Formation of Oligocene or early Miocene age (Miller, 1986; Guertin and others, 2000) (fig. 2). Although carbonate rocks of Ocala
Limestone and Suwannee Limestone are reported to be present in southeastern Florida (Miller, 1986; Reese, 1994; Reese and Memberg, 2000; Reese and Richardson, 2008), no evidence was observed to indicate the presence of the Ocala Limestone and Suwannee Limestone in the study area (fig. 2). Composing both the intermediate confining unit and the uppermost part of the Floridan aquifer system, the Hawthorn Group ranges in age from possibly late Oligocene to early Pliocene (Wingard and others, 1994; Guertin and others, 2000; Cunningham and others, 2001a; Cunningham and others, 2003) and contains the Arcadia and Peace River Formations (Scott, 1988).

\section{Geologic Units and Lithology}

Duncan and others (1994b, p. 30) describe the Avon Park Formation (fig. 2) in southeastern Florida as "characterized by white to yellowish-gray limestones ranging from packstone to mudstone interbedded with very light orange to grayishbrown dolostones that commonly contain organics." The color of Avon Park Formation dolomite (Duncan and others [1994b, p. 30], referred to the sedimentary rock dolomite as "dolostone", an obsolete word use) may be light brown, orange-brown, dark brown, or black and the texture may be sucrosic or dense and microcrystalline. The upper contact of the Avon Park Formation is marked in some places by light-brown, finely crystalline to fossiliferous, dolomitic limestone or dolomite that is thinly interbedded with limestone (Reese, 2004). This contact is defined by an unconformity in west-central peninsular Florida (Arthur and others, 2008), in the Broward County study area, and in all other areas of the peninsula where the Ocala Limestone is absent (Miller, 1986). Applin and Applin (1944) found the cone-shaped, larger benthic foraminifera Dictyoconus to be the most prevalent and consistent larger benthic foraminifera throughout the Avon Park Formation. Powell (2010) observed that this is also the case in core recovered from the upper Avon Park Formation in a test corehole in south-central Florida (Highlands County) north of the study area, which was earlier described by Ward and others (2003).

Total porosity is high (40 percent or greater) in the upper part of the Avon Park Formation (Reese, 2000) and common porosity types are interparticle, intraparticle, intercrystalline, and vuggy. Thick intervals containing mostly dolomite, but commonly interbedded with limestone, are present in the middle to lower part of the Avon Park Formation in southeastern Florida (Reese, 2004). Highly transmissive zones are common in these dolomite units, principally as a consequence of fracture, intercrystalline, and vuggy porosity. The thickness of the formation ranges from about 900 to nearly $1,100 \mathrm{ft}$ in the study area (Miller, 1986, pl. 7).

Some well-construction reports in the study area (Camp, Dresser, and McKee, Inc., 1996; Montgomery Watson, 1996; CH2M HILL, 1999) identify a unit that lies between the Avon Park Formation and the Arcadia Formation as Suwannee 
Limestone. However, the Suwannee Limestone was not identified within the boundaries of the study area described herein, based on lithologic data from the G-2984 test corehole and correlation of these data to other wells in the study. No core samples from G-2984 match the detailed core-sample descriptions of the Suwannee Limestone reported for the Florida Keys (Cunningham and others, 1998) or in central south Florida in Highlands County (Ward and others, 2003). Also, no Ocala Limestone was identified in the G-2984 test corehole, as determined by comparison to the coresample descriptions for a test corehole in Highlands County (Ward and others, 2003).

The Arcadia Formation of the Hawthorn Group in southern Florida, as defined by Scott (1988, p. 56), consists "predominantly of limestone and dolostone containing varied amounts of quartz sand, clay, and phosphate grains. Thin beds of quartz sand and clay commonly are scattered throughout the section." The characteristics that distinguish the Arcadia Formation from underlying units in southeastern Florida are (1) intervals of quartz sandstone or with common subordinate quartz grains; (2) calcareous mudstone intervals; (3) common green, olive-gray, or light gray rock colors; (4) intervals of high phosphate grain content relative to that in underlying units and in some cases having high GR log activity (100 to 200 American Petroleum Institute standard units); and (5) intervals of dolosilt. Missimer (2002) identified 10 lithofacies that compose the Arcadia Formation in southwestern Florida, many of which are similar to lithofacies found in Broward County. These 10 lithofacies are (1) brecciated and laminated packstones (lower Arcadia); (2) laminated, sandy mudstone/wackestone (lower Arcadia); (3) laminated clay; (4) laminated, microsucrosic, dolomitic mudstone/ wackestone; (5) muddy, quartz sand and mollusks; (6) sandy, molluscan skeletal wackestone; (7) sandy, molluscan, echinoid, bryozoan, wackestone; (8) Hyotissa (genera) packstone (wackestone); (9) molluscan wackestone (low quartz sand content); and (10) bryozoan wackestone (minor quartz sand). The lithologies described by Missimer (2002) for the Arcadia Formation more closely resemble those present in the G-2984 test corehole in Broward County than do the lithologies for the Arcadia Formation beneath the Florida Keys described by Cunningham and others (1998). The major difference is a much higher concentration of siliciclastics - quartz sand and silt, and terrigenous clay-in the core samples from Broward County.

In the Peace River Formation, quartz sand is predominant, but sediment and rock can include terrigenous mudstone and limestone. The quartz sands are characteristically clayey, calcareous to dolomitic, phosphatic, very fine to medium grained, and poorly consolidated (Scott, 1988, p. 79). Cunningham and others (2001a) recognized five lithofacies composing the Peace River Formation in the Florida Keys and southern peninsular Florida: diatomaceous mudstone, terrigenous mudstone, clay-rich quartz sand, quartz sand, and pelecypod-rich quartz sand and sandstone.
Geologic units that overlie the Hawthorn Group in southeastern Florida include (1) the Tamiami and Stock Island Formations of Pliocene age (Guertin and others, 2000); (2) Pleistocene-age units composed mainly of the Fort Thompson Formation, Anastasia Formation, Miami Limestone and Pamlico Sand; and (3) undifferentiated sediments of Holocene age (fig. 2). These units constitute the surficial aquifer system, which includes the Biscayne aquifer. In the western part of the study area, the Ochopee Limestone Member of the Tamiami Formation composes the gray limestone aquifer - a minor aquifer within the surficial aquifer system (Fish, 1988; Reese and Cunningham, 2000).

\section{Stratigraphic Markers}

The stratigraphic framework of eastern Broward County was mapped by identifying and correlating the stratigraphic and geophysical-log markers across the study area. A stratigraphic marker is a "an easily recognized stratigraphic feature having characteristics distinctive enough for it to serve as a reference or datum or to be traceable over long distances, especially in the subsurface, as in well drilling or in mine working, e.g., a stratigraphic unit readily identified by characteristics recognized on an electric log, or any recognizable rock surface such as an unconformity" (Neuendorf and others, 2005). A stratigraphic marker horizon is "a marker represented by a rock surface or stratigraphic level, such as a vertical or lateral boundary based on electric or other mechanically recorded logs, that may serve to delineate lithostratigraphic units" (Neuendorf and others, 2005). Two types of stratigraphic markers were used primarily in construction of the stratigraphic framework: (1) a geophysical-log marker delineated principally on the basis of correlation of geophysical data between boreholes and; (2) where available, lithostratigraphic boundaries, which are referred to as lithostratigraphic marker horizons. Three lithostratigraphic marker horizons and three geophysical-log marker horizons are identified in eastern Broward County, and they divide the Avon Park Formation and Arcadia Formation into six informal stratigraphic units (fig. 2, table 1). All six of these stratigraphic markers have characteristic patterns in borehole geophysical GR and sonic $\Delta t$ data, but the three lithostratigraphic marker horizons also display distinct lithologic changes that are laterally persistent and recognizable (table 1). Both types of stratigraphic markers were delineated in the study area, primarily through correlation of borehole geophysical data between wells.

Stratigraphic marker horizon depths were determined in at least one well at each site in the study (appendix table 1-4). All or some of the geophysical-log marker horizons were not determined at each site because wells were not deep enough to penetrate them. The stratigraphic units defined by these marker horizons are illustrated in data plots for wells at five sites (figs. 3-8). Stratigraphic units are described below in order of decreasing depth. The lithologic distinctions associated with 
Table 1. Lithostratigraphic and geophysical-log units identified or defined in the study.

[UAP, Upper Avon Park]

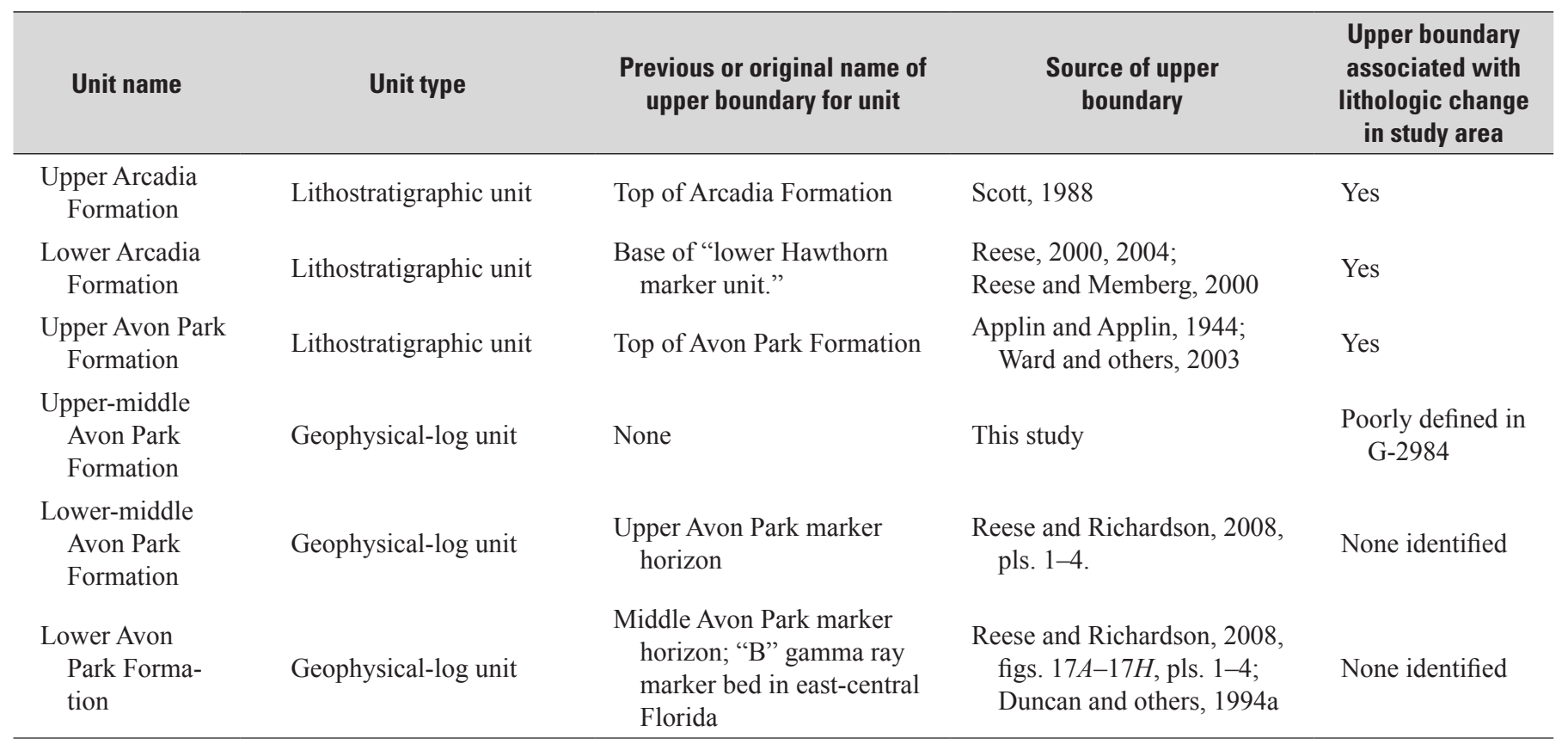

the formation contacts and lithostratigraphic marker horizons, if evident, are based on lithologies described for this study, including those for test corehole G-2984, and lithologies described by others in the study area.

The geophysical-log marker horizon defining the upper surface of the lower Avon Park Formation is identified by correlation of characteristic borehole geophysical log patterns in southern and central Florida, where it has been previously referred to as the middle Avon Park marker horizon or MAP (Reese and Richardson, 2008). This marker horizon is identified in east-central Florida by the " $\mathrm{B}$ " gamma ray marker bed described by Duncan and others (1994a, p. 17), which separates the "more thinly-bedded strata of the upper Avon Park Formation from more thickly-bedded and massive units of the lower Avon Park Formation." Duncan and others (1994b) demonstrated the continuity of this geophysical-log marker horizon between east-central and southeastern Florida using GR and sonic log curves. This marker horizon was previously identified in seven wells in Broward County in Reese and Richardson (2008) [sections $D-D^{\prime}$ (fig. 17D), $E-E^{\prime}$ (fig. $17 E$ ), and $Y-Y^{\prime}$ (fig. $17 H$, pl. 4), section lines shown in fig. 1 of this study, and well BCN-I1]. A change in lithology across this marker horizon in the study area, if present, was not identified, perhaps because descriptions of cuttings samples from previous studies or well-construction reports lacked the resolution to indicate any such change.

The geophysical-log marker horizon defining the upper surface of the lower-middle Avon Park Formation was previously delineated in four wells in Broward County (Reese and Richardson, 2008, section $Y-Y^{\prime}$, fig. 10D, pl. 4,
UAP geophysical-log marker). No distinguishing lithologic characteristics for this marker horizon have been observed in the study area, possibly because cuttings sample descriptions lack sufficient detail. Sonic $\Delta \mathrm{t}$ data, however, indicate this horizon approximately coincides with the top of a vertical succession of variations in geophysical log character having overall lower sonic $\Delta t$ than does the overlying upper-middle Avon Park Formation, and an increase in sonic $\Delta \mathrm{t}$ variations over very thin vertical intervals represented by high and low sonic $\Delta \mathrm{t}$ values that produce a spikey log pattern (figs. 4-7, pls. 1-3).

The geophysical-log marker horizon defining the top of the upper-middle Avon Park Formation is defined in the study area by (1) a slight downward increase in GR values to a background GR level for the Avon Park Formation, and (2) the base of thin (3 to $10 \mathrm{ft}$ ) zones of sharply alternating high and low sonic $\Delta \mathrm{t}$ values, producing a spikey log pattern (for example, figs. 5 and 6). A zone of lower GR values, and in many cases greater sonic $\Delta \mathrm{t}$ variability, usually extends about 20 to $30 \mathrm{ft}$ upward from this marker into the upper Avon Park Formation and can be correlated to all the sites in the study area (figs. 4-8; pls. 1-3). At or near the upper surface of the middle Avon Park Formation in G-2984 there is an upward increase in the thickness of dense, gray mudstone layers. These layers and other lithologic changes could indicate an overall shift toward a shallower marine environment.

On the basis of observations of lithologies in the G-2984 test corehole, the unconformity at the upper contact of the Avon Park Formation is overlain by a basal interval of the Arcadia Formation that is $10 \mathrm{ft}$ thick or less and composed 
EXPLANATION

Primary lithology

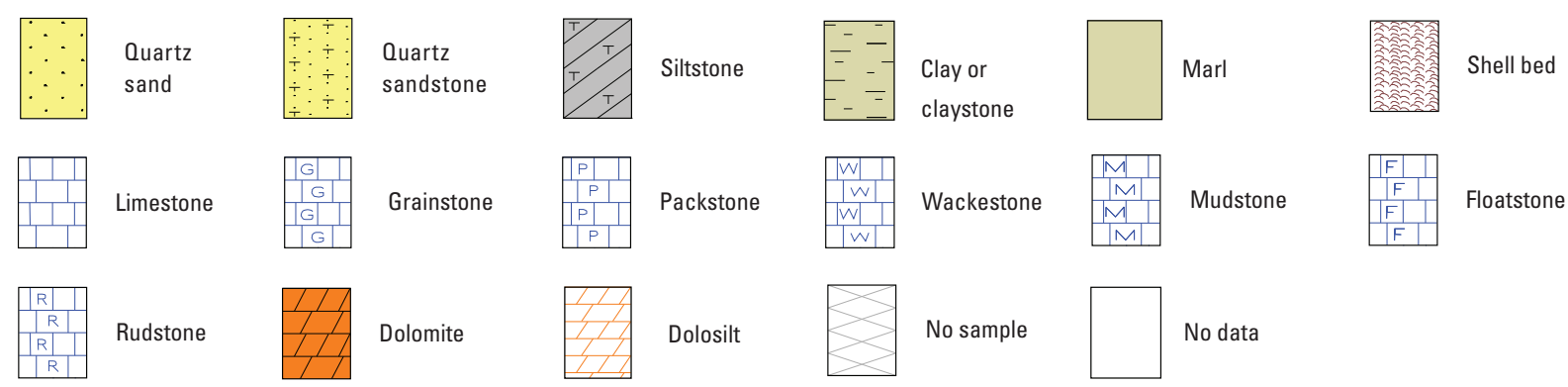

Accessory lithologic components or modifiers

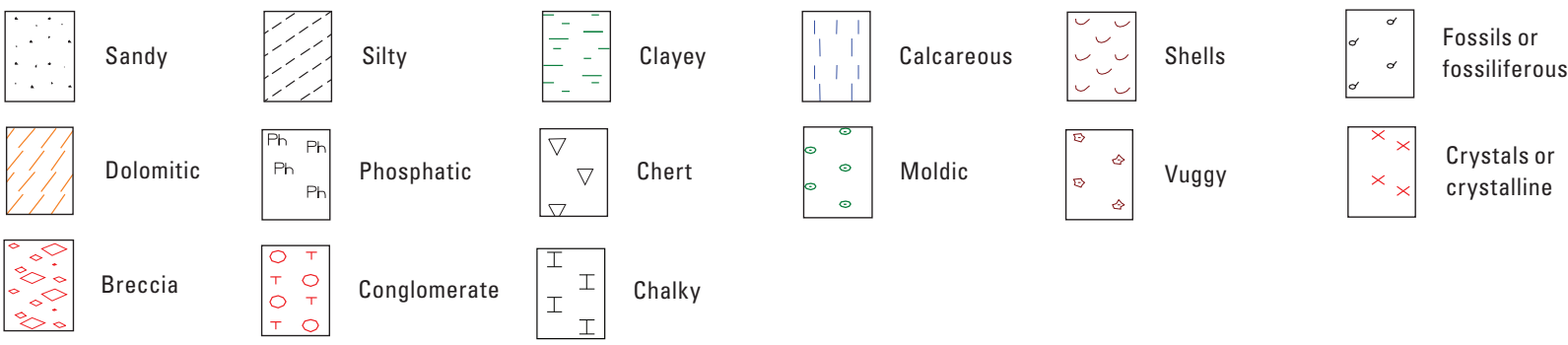

High frequency depositional cycle characteristics

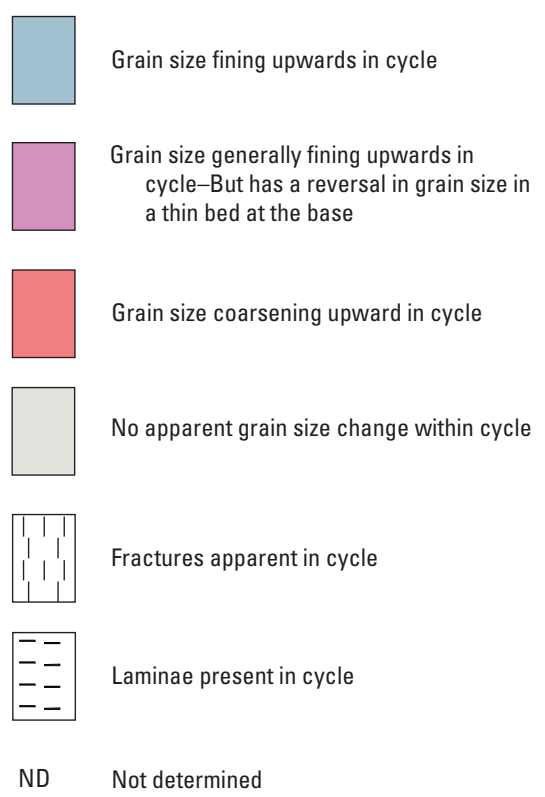

Depositional sequence characteristics and boundaries

\footnotetext{
AR4 Arcadia Formation sequence 4

AR3 Arcadia Formation sequence 3

AR2 Arcadia Formation sequence 2

AR1 Arcadia Formation sequence 1

AP2 Avon Park Formation sequence 2

AP1 Avon Park Formation sequence 1 Interpreted as prograding-Lower
relative sea level

Interpreted as transgressive-Higher relative sea level
? Depth of top of the Avon Park Formation sequence 1 is less certain-Because borehole geophysical image log data were not collected in the well

Depth of bottom of the Avon Park Formation sequence 1 is unknown

ND Not determined
}

Figure 3. Explanation for figures 4 through 8, 14, 25 and 29. 
Lithostratigraphic unit and corresponding upper boundaries

Upper Arcadia Formation

Lower Arcadia Formation

Upper Avon Park Formation

Upper-middle Avon Park Formation

\section{Flow zones evaluated in open hole intervals using borehole flowmeter and fluid properties geophysical data and shown in flow zone column}

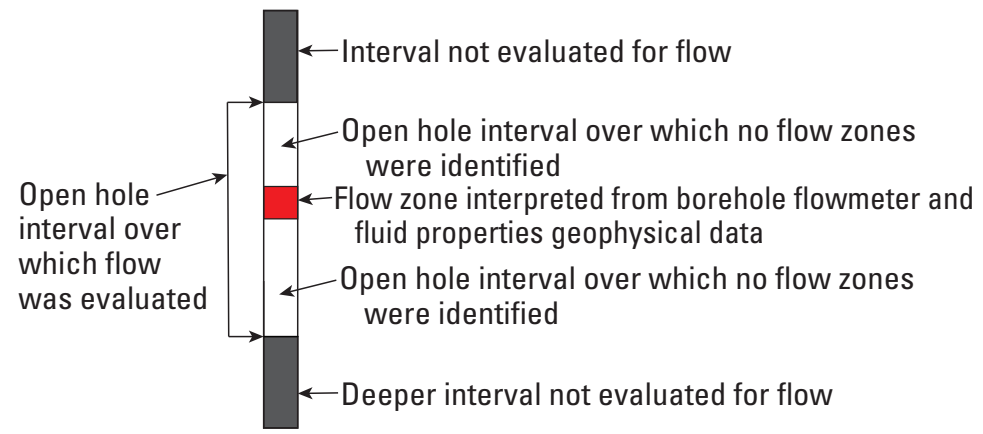

Lower Avon Park Formation

Packer test interval
Interval drilled in deeper test well at same site, and top of interval indicates total depth and base of open interval in monitoring well
Hydrogeologic unit

Intermediate confining unit

Upper Floridan aquifer

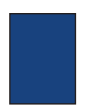

Middle semiconfining unit

Avon Park permeable zone
Lower Floridan aquifer uppermost major permeable zone

Lower Floridan aquifer confining unit

Abbreviations for borehole geophysical log curves

\begin{tabular}{|c|c|c|c|}
\hline $\begin{array}{l}\text { Abbreviation for } \\
\text { logging tool } \\
\text { or device }\end{array}$ & Description & Unit of measure & Description \\
\hline $\operatorname{CAL}(-5)^{1}$ & Caliper & In. & Inch \\
\hline GR (spliced) $)^{2}$ & Gamma ray & GAPI & $\begin{array}{l}\text { American Petroleum Institute } \\
\text { standard unit }\end{array}$ \\
\hline GAMM & Gamma ray & CPS & Counts per second \\
\hline RIL & $\begin{array}{l}\text { Resistivity from slim hole induction } \\
\text { tool- } 40 \text { centimeter radius of investigation }\end{array}$ & ohm-m & Ohm-meter \\
\hline Sonic DT & $\begin{array}{l}\text { Sonic interval transit time or } \\
\text { delta T-Compensated }\end{array}$ & $\mu \mathrm{sec} / \mathrm{ft}$ & Microsecond per foot \\
\hline XCAL, YCAL & $\begin{array}{l}\text { X-caliper and Y-caliper-Both on same tool } \\
\text { and } 90 \text { degrees apart }\end{array}$ & In. & Inch \\
\hline
\end{tabular}

${ }^{1}$ Number indicates data collection interval number.

${ }^{2}$ (spliced) indicates more than one data collection interval is included. If intervals overlap, splicing was done at the greatest depth of the upper interval.

Figure 3. Explanation for figures 4 through 8, 14, 25 and 29-Continued. 


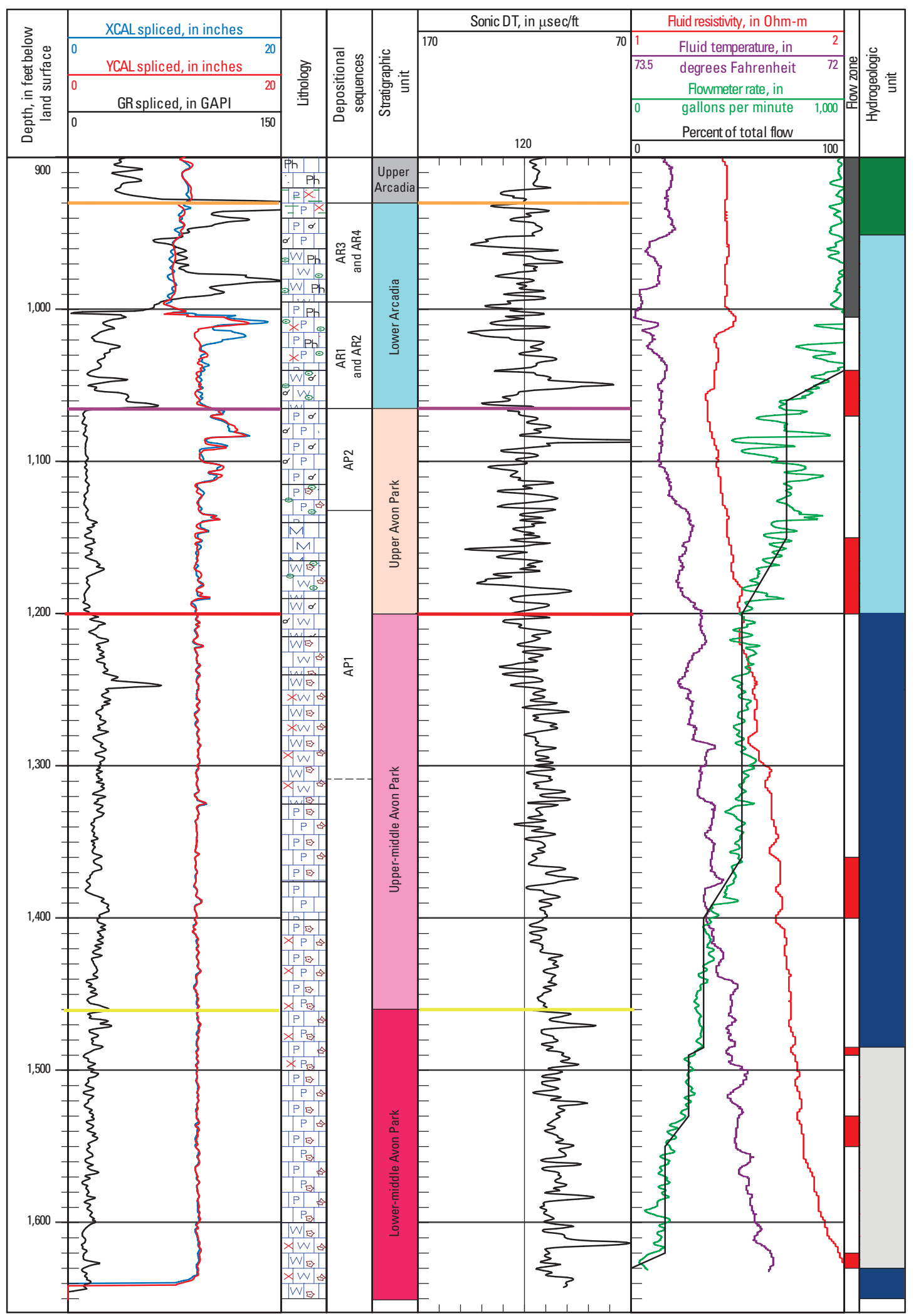

Figure 4. Borehole geophysical logs and lithologic data collected for well PB-1775 at site 16. Fluid resistivity, temperature and flowmeter data were collected under flowing and static conditions. The flowmeter rate was calculated by subtraction of static from flowing values, calibration in casing, and correction for borehole size using caliper log data. 


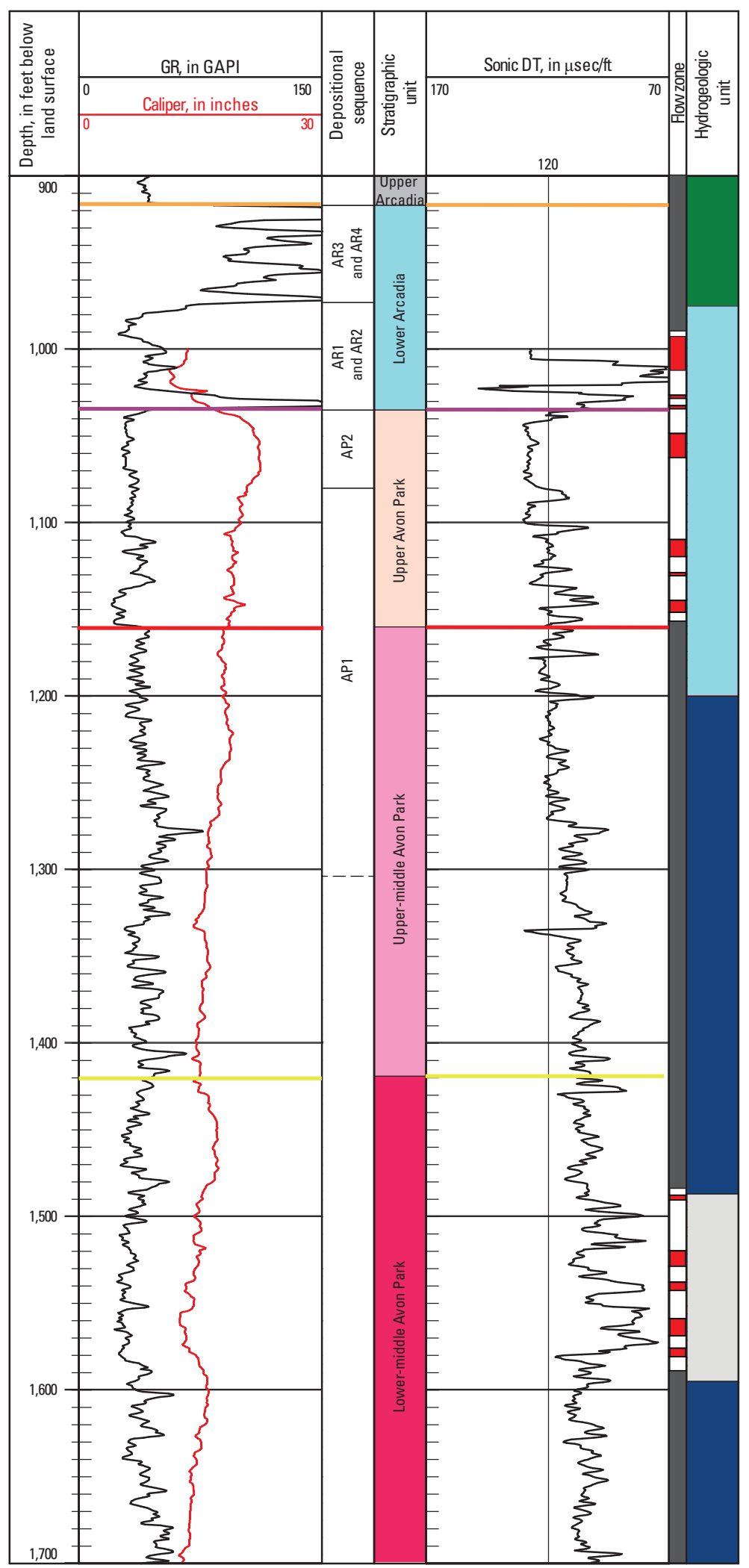

Figure 5. Borehole geophysical logs collected for well G-2938 at site 6 . Expanded plots of one other well at this site are shown in figures 25 and 26. 


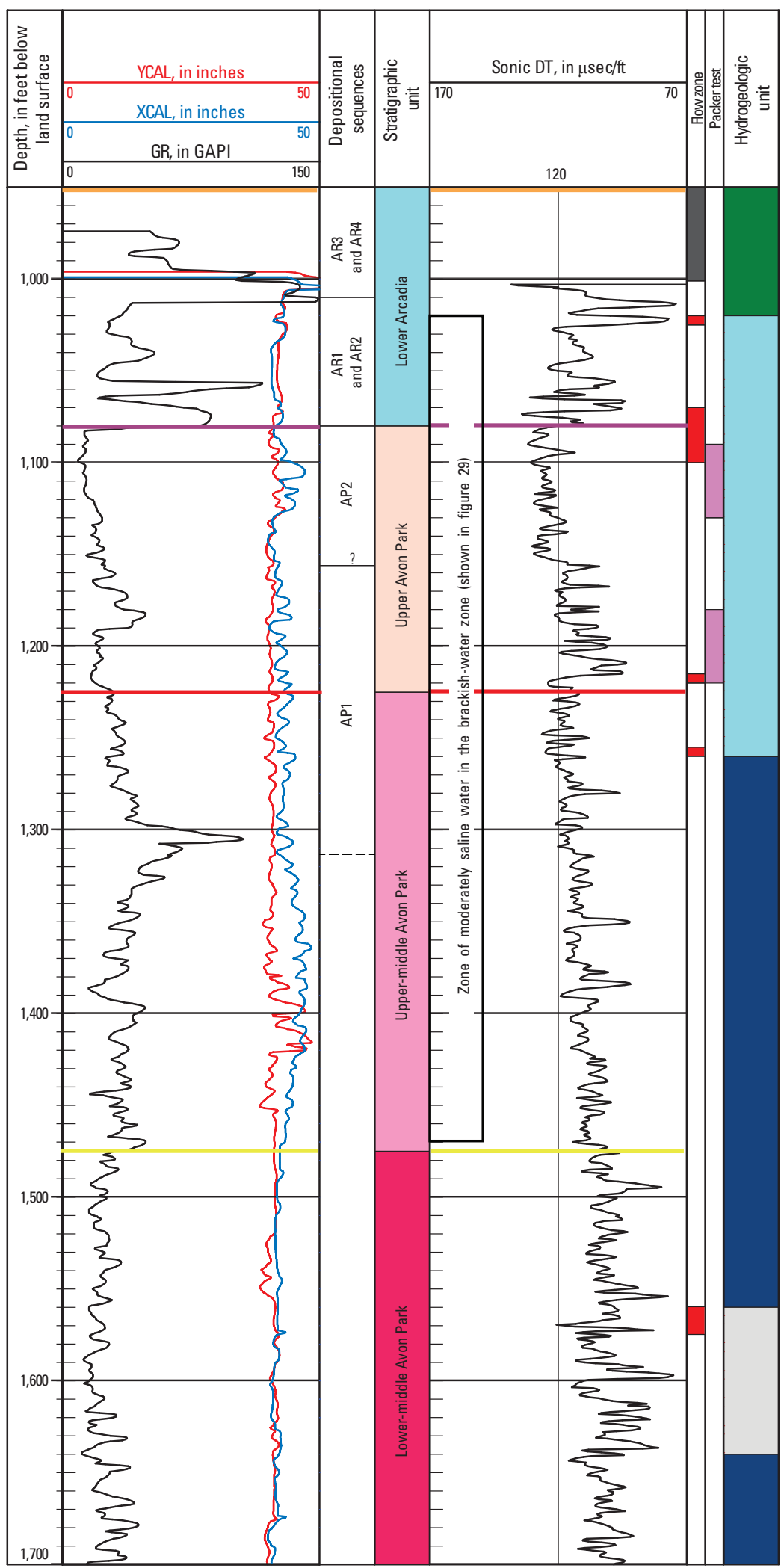

Figure 6. Borehole geophysical logs collected for well CS-12 at site 5. Data from this well are also shown in figure 29. 


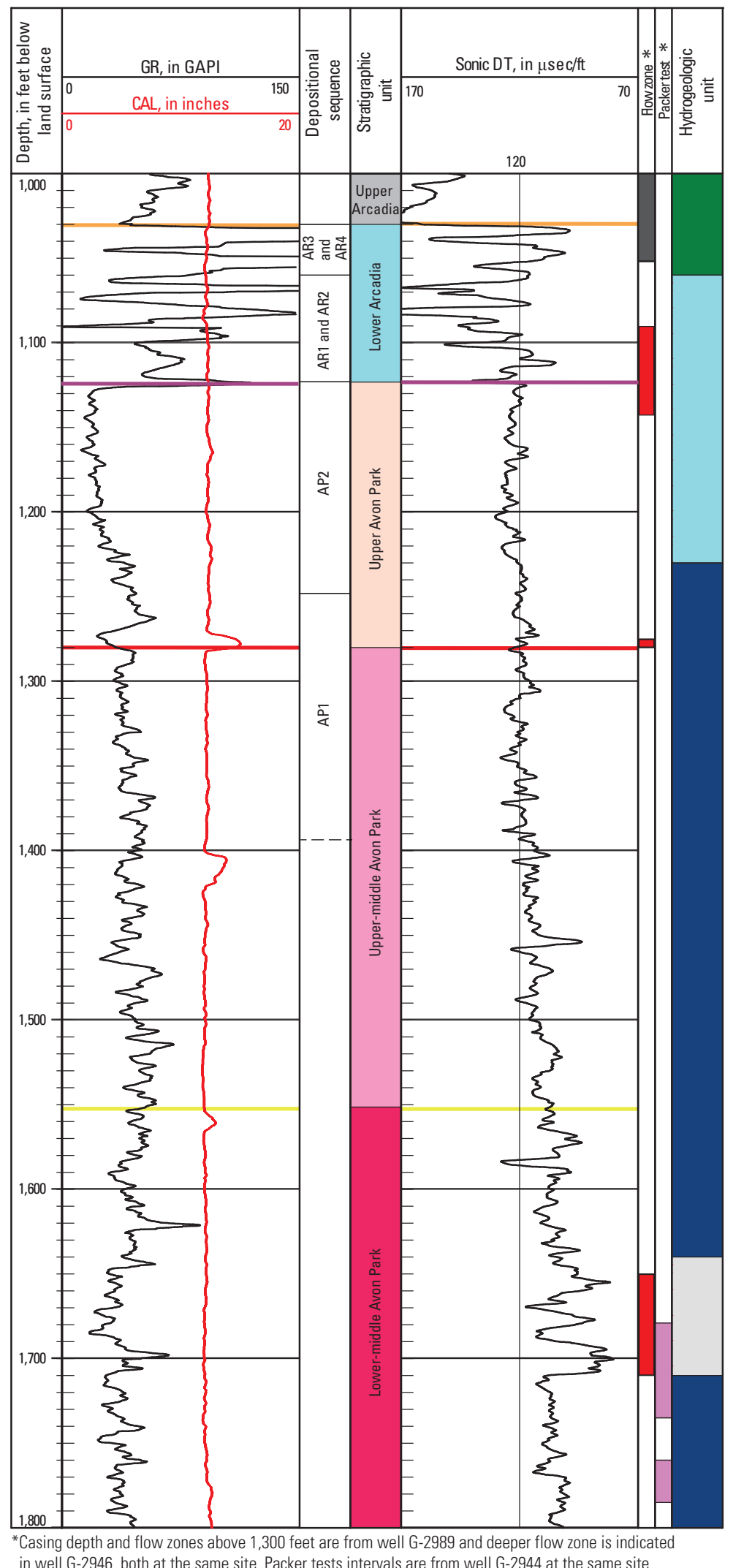

Figure 7. Borehole geophysical logs collected for well G-2945 at site 23. 


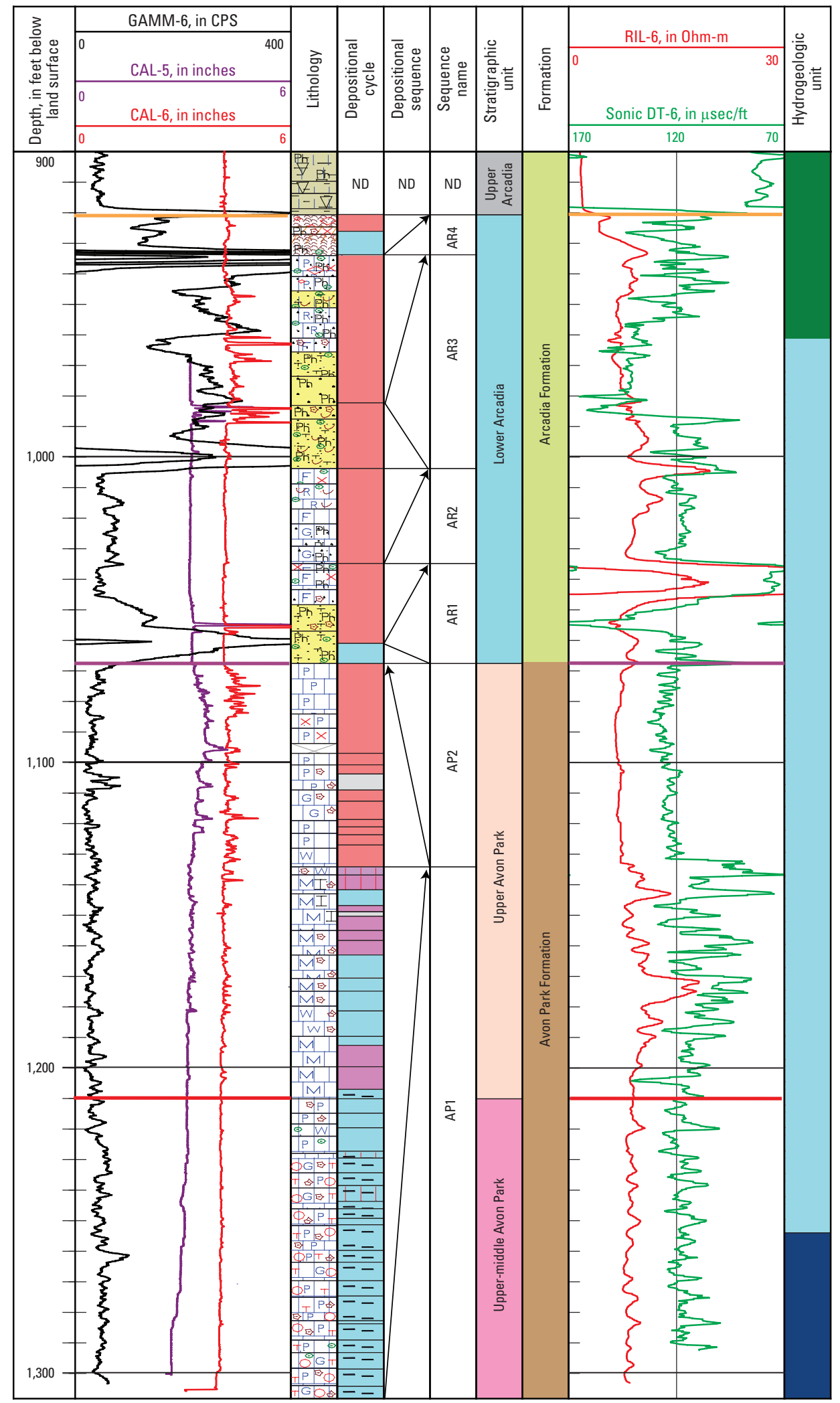

Figure 8. Borehole geophysical logs, lithologic data, and depositional cycles and sequences for test corehole G-2984 at site 18. Data from this well are also shown in figures 14, 21, 22, and 24 . 
of phosphate-grain-rich limestone, quartz sand, and quartz sandstone (fig. 8). The lithology of the uppermost Avon Park Formation just below this unconformity is markedly different in that it is a fine to very coarse grained, benthic foraminifer grainstone and packstone that does not contain phosphate or quartz grains. The limestone of the Avon Park Formation also contains conical, larger benthic foraminifera including Fallotella floridana (Jacqueline B. Powell, Paleo Solutions, LLC., oral comm., 2013). Fallotella floridana is absent throughout the Arcadia Formation. In the logs for most wells examined in this study, there is an abrupt increase in GR values on GR logs across the unconformity, with values in the Avon Park Formation notably lower than values in the lowermost part of the overlying Arcadia Formation. The fossil assemblage within the lowermost Arcadia Formation is commonly dominated by echinoids, pelecypods, and gastropods. Further, the dominant color of the limestone near and at the upper surface of the Avon Park Formation is a very pale orange (10YR 8/2), whereas the basal rocks and quartz sand of the Arcadia Formation most commonly are yellowish gray (5Y 8/1) (Geological Society of America, 1995).

The Arcadia Formation is informally divided into two lithostratigraphic units, the lower Arcadia Formation and the upper Arcadia Formation (figs. 2, 4-8). Observations noted in core samples and optical borehole images acquired from the G-2984 test corehole and GR geophysical values from the same test corehole provide the physical criteria for division of the two lithostratigraphic units, and a GR-log-based stratigraphic marker horizon provides a means of county-wide correlation of the upper contact of the lower Arcadia Formation. In core samples from the test corehole G-2984 (fig. 8), this marker horizon is identified as a drowning unconformity (a substantial change in sediment composition and distribution associated with marine submergence of a carbonate platform; Schlager, 2005) at the upper boundary of the lower Arcadia Formation (depth of $920.6 \mathrm{ft}$ bls), whereas below the unconformity, a 1-ft thick interval of limestone is partly phosphatized and contains common phosphate grains. Petrographic observations of a thin section provide the evidence for the presence of phosphatized rock and phosphate grains. The phosphate produces relatively high GR values on the GR log from the G-2984 test corehole when compared to the GR log values above and below the phosphatized limestone (fig. 8). Overlying the unconformity at $920.6 \mathrm{ft}$ bls in the G-2984 test corehole, the rock at the base of the upper Arcadia Formation is a calcareous mudstone to claystone. The upper contact of the lower Arcadia Formation corresponds to the base of a previously defined "lower Hawthorn marker unit" mapped in Lee, Hendry, and Collier Counties (Reese, 2000), Palm Beach County (Reese and Memberg, 2000), and Martin and St. Lucie Counties (Reese, 2004). The characteristic log pattern of GR values in this lower Hawthorn marker unit, which is the same as the lower part of the upper Arcadia Formation, is consistent over large parts of southern Florida.

The upper contact of the Arcadia Formation is usually well defined on GR logs as a pronounced peak produced by high GR values. In southeastern Florida, this contact is marked by an "increase in the abundance in large (GR) peaks in the Arcadia" as compared to the GR values in the overlying siliciclastics of the Peace River Formation (Scott, 1988, p. 125). The peak at the upper contact of the formation can be readily correlated between most wells in the study area and may be associated with a limestone layer containing concentrated phosphate grains or gravel that has been referred to as a "phosphatic rubble zone" (Scott, 1988, p. 58). This layer was found to be several feet thick in G-2984, and in the Florida Keys the uppermost limestone of the Arcadia Formation is phosphatized over a thin interval below the upper bounding surface of the formation (Cunningham and others, 1998). The formation contact bounding the upper surface of the Arcadia Formation represents either a major composite sequence boundary (Cunningham and others, 1998) or a depositional sequence boundary (Guertin and others, 2000; Missimer, 2002).

\section{Structure and Thickness of Lithostratigraphic Units}

In the study area, the altitude of the surface that forms the upper contact of the Avon Park Formation trends upward about $150 \mathrm{ft}$ from west to east (fig. 9). The generally westward dipping structure at the upper contact of the Avon Park Formation in the study area has been mapped previously (Reese, 1994; Reese and Richardson, 2008). A structural low or basin extends north to south in central Broward and MiamiDade Counties, and relief of about $200 \mathrm{ft}$ was mapped from the coast to central Miami-Dade County (Reese, 1994, fig. 6). The altitude of the upper contact of the Avon Park Formation ranges from 1,127 ft below NGVD 29 at well G-2989 in the southwestern part of the study area to $954 \mathrm{ft}$ below NGVD 29 at well G-2962 in the southeastern part. The altitude of the upper contact decreases across I-595 in the south-central part of the study area from south to north by 20 to $40 \mathrm{ft}$, indicating that a structural flexure or offset along a buried subsurface fault may be present in the vicinity of the highway (fig. 9). A structural low having as much as $50 \mathrm{ft}$ of relief is indicated in the northeastern part of the study area, centered on well G-2942 (site 28, fig. 9).

An isolated structural low at the upper contact of the Avon Park Formation was mapped around test corehole G-2984 (site 18, fig. 9), and based on the regional structural trend in the area, the altitude of the upper contact of the Avon Park Formation at this well is as much as $80 \mathrm{ft}$ deeper than the projection of the regional structural trend across the well location. Corroborating evidence for the structural low at G-2984 is a comparison of the altitude of the upper contact and thickness of the upper Arcadia Formation at well G-2984 to that at nearby well G-2968 (site 8, fig. 9). At G-2984, the thickness of the upper Arcadia Formation is $62 \mathrm{ft}$ greater than at well G-2968 (appendix table 1-4, pl. 1). This greater thickness of the upper Arcadia Formation and the lower altitude of the upper contact of the upper Arcadia Formation 

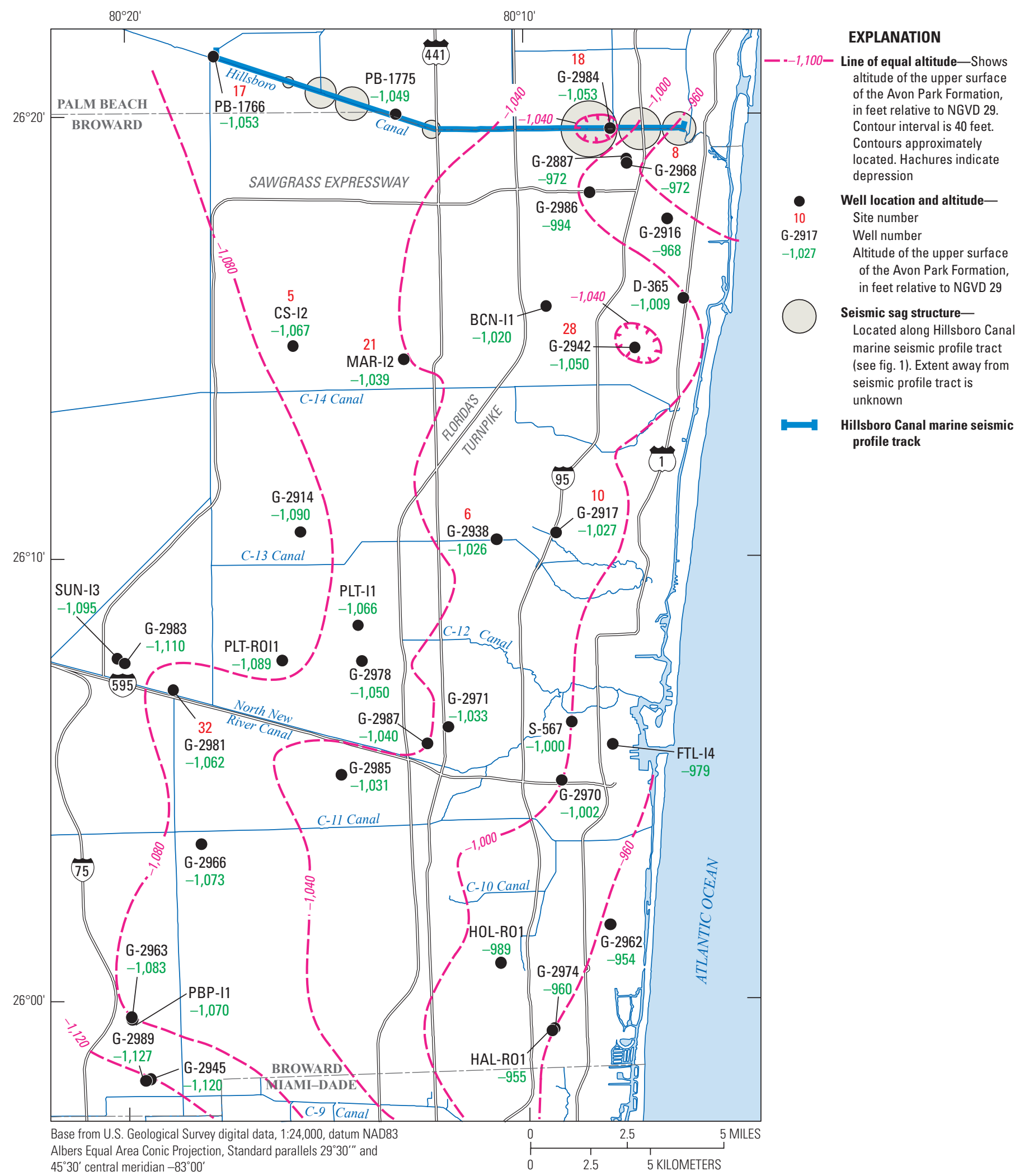

Figure 9. Altitude of the upper contact surface of the Avon Park Formation. 


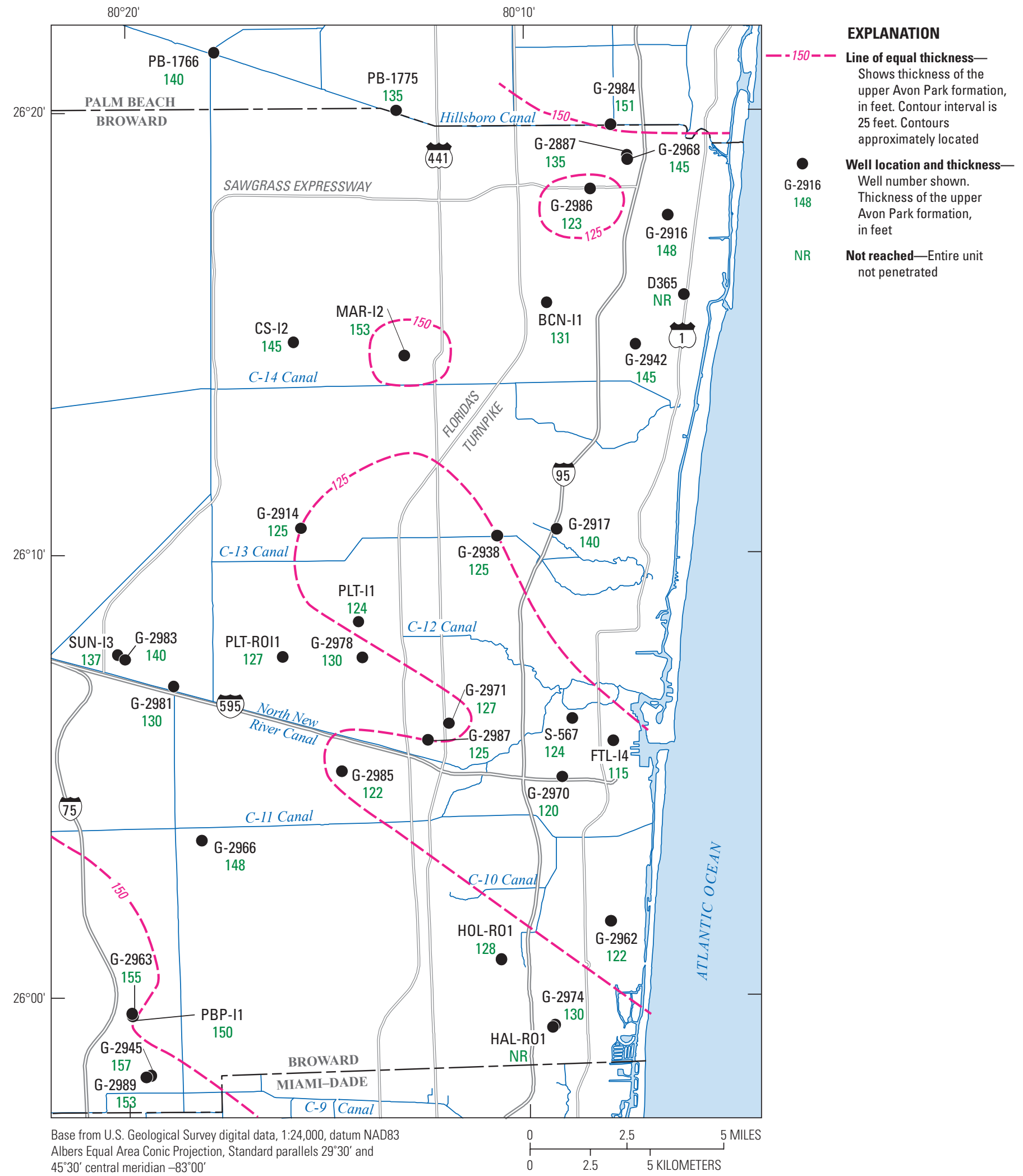

Figure 10. Thickness of the upper Avon Park Formation. 
at G-2984 compared to that at G-2968 indicate that G-2984 is located in a paleo-low area that was filled in with sediments during deposition of the upper Arcadia Formation. Seismic data indicate that the isolated structural low at G-2984 is the result of a deeply buried, collapsed cave system. The structural low at well G-2942 could have a similar origin.

Generally, the upper Avon Park Formation is thickest in the northwestern, extreme northeastern, and southwestern parts of the study area and thins towards the central and southeastern parts, including areas along and north of I-595. The thickness of the upper Avon Park Formation ranges from $115 \mathrm{ft}$ at well FTL-I4 in the east-central part of the study area to $157 \mathrm{ft}$ at well G-2945 in the southwestern part of the study area (fig. 10).

Generally, the thickness of the lower Arcadia Formation increases from south to north, with most of the thickening occurring to the north of I-595. The thickness of the lower Arcadia Formation in the study area ranges from $80 \mathrm{ft}$ at well PBP-I1 in the southwestern part of the study area to $155 \mathrm{ft}$ at well G-2942 in the northeastern part of the study area (fig. 11).

\section{Sequence-Stratigraphic Analysis}

In sequence stratigraphy, depositional sequences are genetically-related strata that can be arranged in units that are bounded by surfaces of erosion, or nondeposition, or their correlative conformities (Van Wagoner and others, 1988). The emphasis in sequence stratigraphy on unconformity-bound depositional sequences differs from the simple lateral correlation of similar rock types between subsurface data points in more conventional lithostratigraphy. Because hydrologic properties commonly are physically associated with specific lithologies, and may be spatially associated with erosional or nondepositional surfaces, recognition of depositional sequences may improve correlation of hydrologic units and improve the accuracy of the hydrologic framework.

Prior to this study, borehole geophysical data correlations had been primarily used to develop conceptual geologic frameworks for Floridan aquifer system rocks in Broward County. Improvement of the spatial resolution of lithostratigraphy and cyclostratigraphy by using sequence stratigraphy for a part of the vertical range of Floridan aquifer system rocks has resulted in refinement of the Floridian aquifer system hydrogeologic framework. The preliminary sequence stratigraphy developed for the lower Arcadia Formation and an upper part of the Avon Park Formation in this study needs to be tested further and a robust geologic data base compiled to develop a more extensive and still more refined hydrogeologic framework.

The terminology of sequence stratigraphy is complex, and its concepts are continually evolving (Catuneanu and others, 2009). The fundamental sequence-stratigraphic unit is the high-frequency cycle (HFC or parasequence), which is a depositional cycle defined by a distinct vertical lithofacies succession and bounded at the top and bottom by surfaces across which there is evidence for an abrupt, relative change in sea level (Kerans and Tinker, 1997). The cycle hierarchy used herein indicates two relative positions in the cycle hierarchy shown in table 2 , in which the cycles are either of short duration (high order) or long duration (lower order). The short duration cycles are defined as HFCs and the long duration cycles are defined as depositional sequences. The depositional sequences would probably be equivalent to the third-order composite or depositional sequences delineated for depositional cycles of the Avon Park Formation by Ward and others (2003). No absolute time duration is implied for the HFCs and depositional sequences. This cycle terminology for Broward County is tentative and its refinement will require further testing.

Table 2. Nomenclature of stratigraphic cycle hierarchies and order of cyclicity. Modified from Kerans and Tinker (1997, fig. 1.11).

$[<$, less than the value; $>$, greater than the value $]$

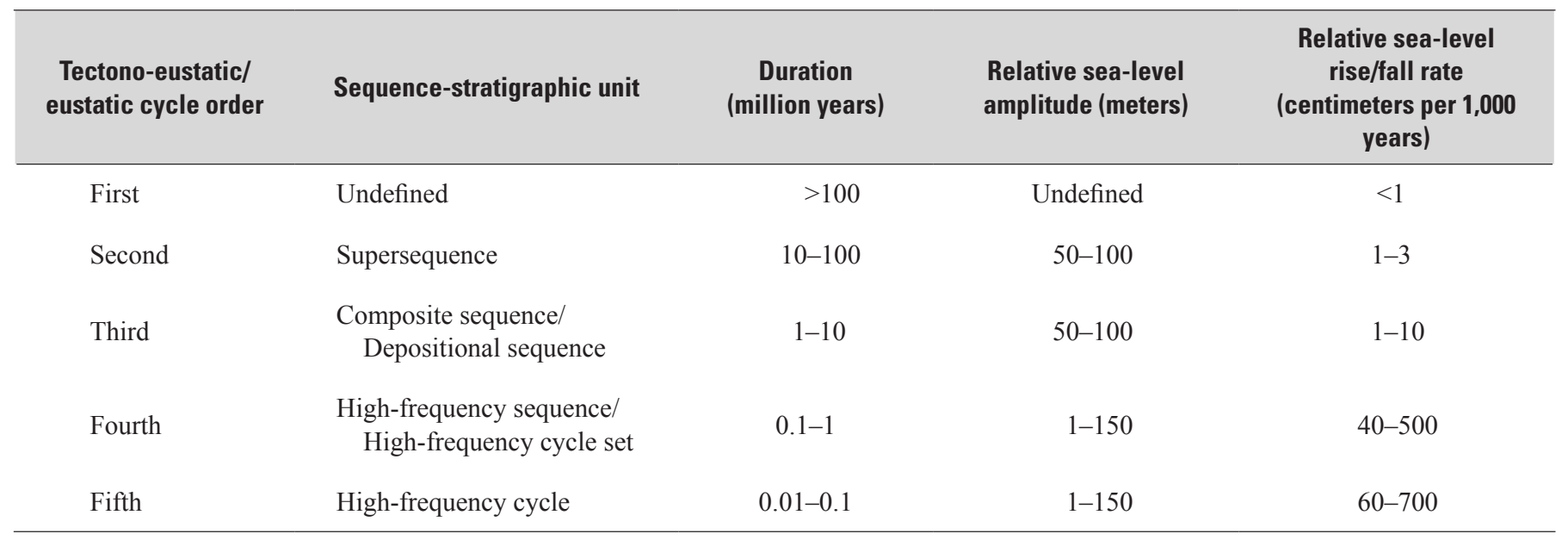




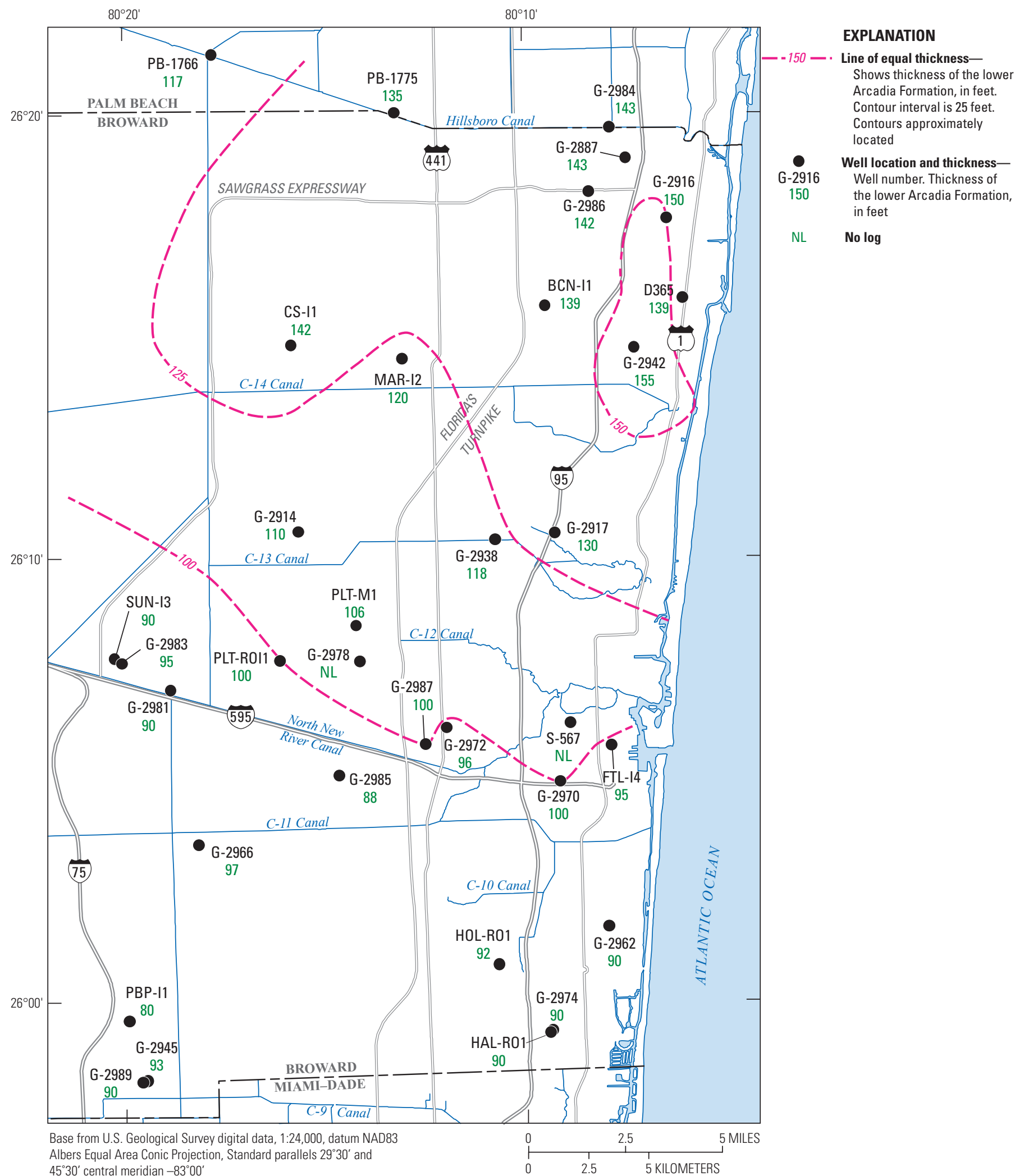

Figure 11. Thickness of the lower Arcadia Formation. 


\section{Sequence Stratigraphy at Test Corehole G-2984}

A preliminary sequence stratigraphy was delineated for the upper part of the upper-middle Avon Park Formation (1,309 to $1,210 \mathrm{ft}$ bls), the upper Avon Park Formation $(1,210$ to $1,068 \mathrm{ft}$ bls), and the lower Arcadia Formation ( 1,068 to $921 \mathrm{ft}$ bls), on the basis of examination of core samples and borehole wall images acquired from test corehole G-2984 (fig. 8). In southeastern Florida, this well provided core samples from the thickest continuously cored interval to date of any part of the Avon Park Formation.

Six depositional sequences were identified between 1,309 and $921 \mathrm{ft}$ bls in the G-2984 test corehole (fig. 8). From deepest to shallowest, these sequences are Avon Park sequence 1 (AP1), Avon Park sequence 2 (AP2), and Arcadia sequences 1 through 4 (AR1-AR4). The upper bounding surface of each sequence generally is an unconformity, and in some instances, evidence in core samples suggests subaerial exposure. In some cases, the sequences boundaries can be correlated throughout the study area using borehole geophysical logs.

\section{Upper-Middle to Upper Avon Park Formation}

The AP1 and AP2 depositional sequences were delineated in test corehole G-2984 in the upper part of the upper-middle Avon Park Formation and the upper Avon Park Formation (pl. 1). The AP1 sequence extended from the base of the core samples at 1,309 $\mathrm{ft}$ and upward to 1,134 ft bls. Peritidal HFCs compose the AP1 and the AP1 is interpreted as a highstand and progradational phase of the southeastern Florida platform (fig. 8). The penetrated part of AP1 contains $39 \mathrm{HFCs}$, each of which is commonly 3 to $4 \mathrm{ft}$ thick (fig. 8). The base of AP1 was not penetrated in G-2984, so the depth of the lower boundary of the sequence is unknown.

In the G-2984 test corehole, the HFCs in the lower part of the AP1 sequence in the upper-middle Avon Park Formation between depths of 1,309 and 1,210 ft bls (pl. 1) commonly consist of a benthic foraminiferal packstone to grainstone, intraclast floatstone, or echinoid floatstone in the lower part, with grain size fining upward to a thin layer of finely laminated, micrite-rich limestone, or a dense, hard, light gray, lime mudstone cycle cap, or both. This common arrangement of vertical lithofacies is representative of an upward-shallowing cycle from shallow-marine subtidal to tidal flat depositional settings. In the lower part of some HFCs, granule- to pebblesized, angular to rounded, gray limestone intraclasts are dispersed in a matrix of mostly sand-sized benthic foraminiferarich packstone or grainstone. Small (0.5-in. [inch] diameter), disk-shaped echinoids and cone-shaped larger benthic foraminiferal genera (for example, Fallotella) can be abundant in the lower to middle part of the HFCs. The thin layers of finely laminated sediments contain some organic matter and are referred to as stromatolite or laminite (algal tidal flat) facies (table 3), similar to those seen in the Avon Park Formation in south-central Florida (Ward and others, 2003). In many cases, the mudstone layers are at the top of HFCs and are usually less than $1 \mathrm{ft}$ thick. The mudstone layers commonly include large vugs at or near their boundaries, and abundant and pervasive, subhorizontal to subvertical, irregular to tortuous small holes or marks (pinpoint-sized to 0.06-in. diameter) that in many cases appear to be rhizoliths, but also could be produced by burrowing. In some cases, these mudstone layers are brecciated and have an eroded upper surface; they were probably deposited in a mudflat environment with marked subaerial exposure. For some HFCs in the lower part of AP1, the mudstone layer is missing and the algal tidal-flat facies occurs below of the upper bounding surface of the cycles.

Although HFCs are also interpreted to be peritidal, some of the characteristics of the HFCs in the upper part of the AP1 sequence in the upper Avon Park Formation, from 1,210 to $1,134 \mathrm{ft}$ bls in G-2984, differ from those in the lower part of the sequence, between 1,309 and 1,210 ft bls (fig. 8). In the upper part of the AP1 sequence, dense, gray, mudstone layers capping the cycles are thicker than those in the lower part of the sequence, the laminite layers are absent from the upper part of the HFCs, and intraclasts are absent from the lower part of the HFCs. The mudstone layers are commonly greater than $1 \mathrm{ft}$ thick and as thick as 3 to $4 \mathrm{ft}$, and have in addition to the abundant, small pore spaces possibly related to burrowing or rhizoliths, small gastropod molds. In some of the HFCs that contain thick mudstone layers, pervasive, large (1- to 2-in. diameter), irregular, subvertical vugs are present in the mudstone that possibly formed by dissolution along preexisting large rhizoliths or burrows. These large vugs can extend several feet down into the HFC, with their width decreasing downward. Although grain size generally also fines upward within the HFCs in the upper AP1 sequence, some of the HFCs have a reversal in grain size near the base of the HFC, with a finer-grained 0.1- to 1-ft-thick bed of poorly cemented wackestone at the base of the HFC (fig. 8). These thin beds at the base of some cycles may have been deposited in a transitional environment, such as a lagoon, as opposed to a subtidal, shallow-marine environment of deposition prevalent in the lower parts of other HFCs. The AP1 sequence is part of the Avon Park Formation, as evidenced by the common occurrence of repetitive, upward-fining, peritidal HFCs with common subaerial caps (compare with Ward and others, 2003), and the common occurrence of cone-shaped, larger benthic foraminifera, including Fallotella (Powell, 2010).

The AP2 sequence extends from 1,134 up to $1,068 \mathrm{ft}$ bls in the upper part of the upper Avon Park Formation (fig. 8), and is interpreted to be deposited mostly in a subtidal marine environment in which the water depth was greater than that during deposition of the AP1 sequence. This sequence is interpreted to be representative of a transgressive, backstepping phase of the southeastern Florida platform (fig. 8). The 10 HFCs in the AP2 sequence have a similar range in thickness as the HFCs in the AP1 sequence (fig. 8), except for the uppermost HFC, which is $29 \mathrm{ft}$ thick. Subtidal HFCs compose the AP2 sequence. They commonly have a soft, 
Table 3. Avon Park Formation lithofacies in well G-2984. Modified from Ward and others (2003, table 1).

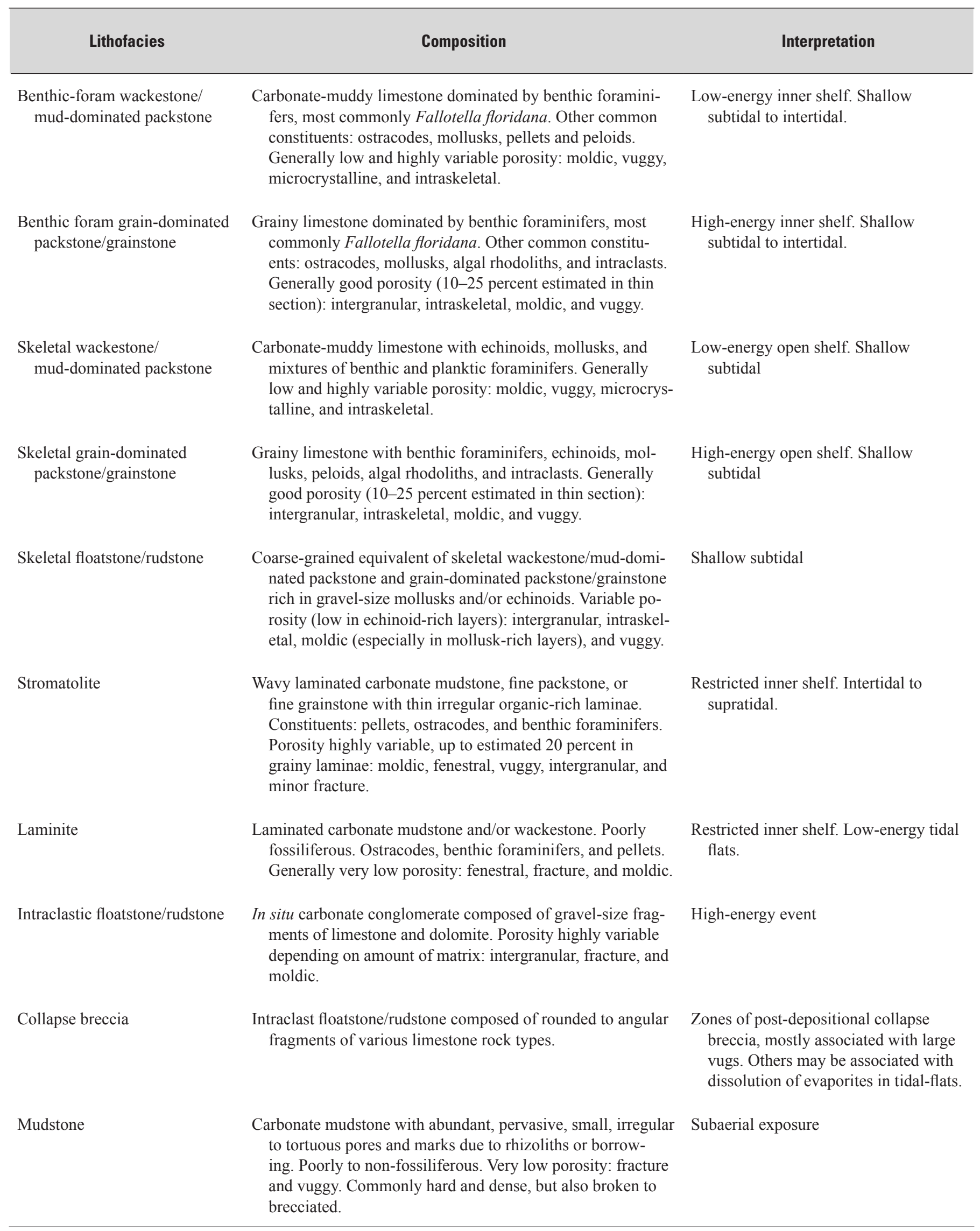


poorly-cemented, benthic foraminifer wackestone depositional texture in their lower part, and in most cases coarsen upward. The top of the HFCs are commonly defined by thin layers ( 0.1 to $0.5 \mathrm{ft}$ thick) of irregularly cemented, medium- to coarsegrained, benthic-foraminifer packstone to grainstone having abundant pinpoint-sized interparticle porosity, and in some cases, large irregular vugs. The upper $0.6 \mathrm{ft}$ of the uppermost HFC of AP2 is well cemented and karstic, and has large $(0.25$ to 0.5 in.) semivertical vugs that may follow preexisting rhizoliths or burrows. The semivertical vugs in this HFC extend downward as much as 3 or $4 \mathrm{ft}$ and are filled with fine, phosphatic, quartz sand that probably filled the vugs during transgression of the upper bounding surface of the AP2 sequence.

The AP2 sequence is part of the Avon Park Formation, with evidence including the similarity of the subtidal lithofacies present in both the AP1 and AP2 sequences and the abundant occurrence of cone-shaped, larger benthic foraminifera throughout (Fallotella; Powell, 2010). Discoid, larger benthic foraminifera characteristic of the Ocala Limestone (Powell, 2010) are not present. Additionally, the Ocala Limestone is interpreted to be deposited in a mid- to outerramp environment that is generally below normal wavebase, rather than in an inner-ramp environment with shallower water depths (Ward and others, 2003).

\section{Lower Arcadia Formation}

The lower Arcadia Formation in test corehole G-2984, which is $147 \mathrm{ft}$ thick, contains four depositional sequences, AR1 through AR4, in ascending order (fig. 8, pl. 1). An erosional unconformity is present at the top of the AR3 and AR4 sequences. Additionally, phosphatization is present at the top of the AR3 and AR4 sequences. Some of these sequence boundaries may represent a long hiatus, and two or more of these sequences grouped together may represent a composite sequence (table 2). The HFCs in these sequences are much thicker than most of the HFCs in the sequences of the upper part of the Avon Park Formation. Only seven HFCs are present in all four sequences, and four of these HFCs are at least $20 \mathrm{ft}$ thick and have coarsening upward grain size. In southwestern Florida, the lower Arcadia Formation (Supersequence A) of late Oligocene age was found to "consist of primarily shoaling-upward sediment packages deposited in shallow water" (Missimer, 2002, p. 150).

The limestone in the AR1 and AR2 sequences is molluscan rudstone and floatstone, packstone, and grainstone with common moldic porosity. The lithology of the 19-ft thick interval below $1,048 \mathrm{ft}$ bls to the base of the AR1 sequence, however, is a quartz sandstone with a high proportion of phosphate grains (as much as 50 percent, fig. 8). Within the AR1 sequence, the top of the lowest HFC, at a depth of 1,061 ft bls, is underlain by a firmground (a submarine depositional surface consisting of a firm substrate) and an associated a Glossifungites ichnofacies. This firmground surface may be a drowning unconformity that formed during a period of high relative sea level (Schlager, 2005).

A unit lying between the Avon Park Formation and the Arcadia Formation is described as the Suwannee Limestone in construction reports for other wells in the study area (Camp, Dresser, and McKee, Inc., 1996; Montgomery Watson, 1996; CH2M HILL, 1999), and this unit is the same interval that includes both the AR1 and AR2 sequences in test corehole G-2984. Evidence herein indicates that these sequences are part of the Arcadia Formation because the rocks and sediment of AR1 and AR2 sequences have the following properties characteristic of the Arcadia Formation (Scott, 1988; Cunningham and others, 1998): (1) the common to abundant occurrence of quartz and phosphate sand, (2) the presence of sucrosic dolomite in some of the limestone and sandstone, (3) a heterozoan carbonate particle assemblage (James, 1997), and (4) the lack of thin, exposure-capped peritidal cycles. At the $\mathrm{W}-17156$ test corehole in the Florida Keys, no phosphorite, quartz sand grains, or dolomite were observed in the Suwannee Limestone (Cunningham and others, 1998). The carbonate particle assemblage prevalent in the AR1 and AR2 sequences in G-2984 is heterozoan, which is similar to that found in the Arcadia Formation in the Florida Keys in the W-17156 test corehole, rather than a chlorozoan carbonate particle assemblage (James, 1997) found in the Suwannee Limestone in that test corehole (Cunningham and others, 1998).

The bottom $39 \mathrm{ft}$ of sequence AR3 is quartzose sand or sandstone with high phosphate grain content (fig. 8), and within this interval, the top of the lowest HFC in the sequence, at $982.3 \mathrm{ft}$ bls, is a possible firmground surface associated with a Glossifungites ichnofacies. The surface may be a transgressive surface followed by progradation in the overlying HFC. Based on the core and the OBI and $\mathrm{ABI} \operatorname{logs}$, in the upper part of the lower HFC in the AR3 sequence from a depth of 985 to $982.3 \mathrm{ft}$ bls, and from a depth of 965 to $961 \mathrm{ft}$ bls in the upper HFC, thin (1-2 ft thick), well-cemented, dense, sandstone or limestone layers are interbedded with uncemented or poorly cemented sand, or possibly bedding plane vugs (fig. 8). The uncemented layers are indicated on the caliper log by thin, abrupt, borehole enlargements (fig. 8) and sediment is visible inside the "vugs" on the OBI log. In the upper HFC of the AR3 sequence, above a depth of $961 \mathrm{ft}$ bls, sandy, phosphatic packstone, rudstone, and floatstone with moldic porosity is the dominant lithology.

The two thin HFCs present in the AR4 sequence are dominated by thick ( 4 to $7 \mathrm{ft}$ ) beds consisting of oyster shell rudstone (fig. 8). The oyster shells are large and thick, and may be whole shells that grew in place. The shell beds have a matrix composed of packstone with rock and shell fragments, or mudstone, or very fine sand- to silt-sized sucrosic dolomite.

\section{Correlation of Sequences Within the Study Area}

On the basis of correlations between borehole geophysical log data and the lithology of core samples from the G-2984 test corehole, the upper surface of the AP1 sequence was identified in wells at other sites in the study area. Using borehole image logs, this boundary was placed at the top of the uppermost HFC that appears to have an 
upper bounding dense, lime mudstone layer. The depth of the upper boundary of the AP1 sequence ranges from 1,010 to $1,248 \mathrm{ft}$ bls in the study area (appendix table 1-4), and this boundary shallows in altitude from east to west in the study area (pls. 1 and 2). In addition, the thicknesses of HFCs in the AP2 sequence commonly increase above this boundary and generally lack cycles capped by lime mudstone. The boundary between the AP1 and AP2 sequences was identified on the basis of analysis of (1) optical borehole imagery in wells G-2916 and G-2940; (2) acoustic televiewer data in wells G-2946, G-2964, G-2982, G-2991, and PB-1775; and (3) formation microresistivity image data in well PB-1841. This boundary was determined with less certainty in additional wells in hydrogeologic sections $A-A^{\prime}, C-C^{\prime}$, and $Z-Z^{\prime}$ (pls. 1-3) and well CS-I2 (fig. 6) using other types of borehole geophysical data, such as sonic, shallow-reading resistivity, and caliper data in combination with lithologic data.

The AP2 sequence thickens from the northeast to the southwest, from $58 \mathrm{ft}$ in well G-2916 (pl. 1) to 95 and $125 \mathrm{ft}$ in wells G-2982 (pl. 2) and G-2945 (fig. 7) respectively. The AP2 sequence also thickens from east to west in the northern part of the study area, from G-2916 to PB-1766 (pl. 1).

The upper boundary of the AR2 sequence was correlated throughout the study area using GR log character and values and lithologic data. The depth of the boundary ranges from to 900 to $1,060 \mathrm{ft}$ bls (appendix table 1-4, pls. 1-3, figs. 4-8). The upper boundary of the AR2 sequence is usually defined by a large GR activity peak that is related to high phosphate grain content. The depth of the upper surface of the AR2 sequence in test corehole G-2984 is at a depth of 1,004 ft bls, and this sequence is overlain by phosphatic quartz sandstone (fig. 8). The combined thickness of the AR1 and AR2 sequences does not vary greatly in the study area, ranging from $52 \mathrm{ft}$ in PB-1766 to $70 \mathrm{ft}$ in CS-I2 and PB-1775 (pls. 1-3, figs. 4-8).

\section{Seismic Stratigraphy and Structure}

Approximately 14 mi of high-frequency, marine seismic-reflection data were acquired along the Hillsboro Canal in northeastern-most Broward County (fig. 12). These data yielded a single, 2-dimensional, high-resolution, seismic-reflection profile that was used to evaluate geologic structures and stratigraphic complexities that cannot be delineated using borehole data alone. The hydrogeologic cross section $A-A^{\prime}$ parallels the seismic-reflection profile along the Hillsboro Canal between wells PB-1766 and G-2984 (pl. 1, fig. 1). Geologic, hydrogeologic, and geophysical data from wells PB-1766, PB-1775, and G-2984 (fig. 1, appendix tables 1-4 and 1-5) were used to correlate the dominant lithostratigraphic, sequence-stratigraphic, and hydrogeologic units identified in the boreholes to the seismic-reflection profile (fig. 13). The seismic profile was especially useful in identifying karst collapse structures, which could disrupt continuity of confining beds within the Floridan aquifer system. Karst features similar to those observed in the Hillsboro seismic-reflection profile are shown on seismic-reflection profiles in southern Florida presented by Cunningham and others (2001b, 2003) and Cunningham and Walker (2009). The integration of borehole datasets and seismic-reflection profiles enhanced delineation of well-to-well horizontal distribution and connectivity of hydrogeologic units.

The Hillsboro Canal seismic-reflection profile is displayed with two vertical scales, indicating two-way travel time and corresponding depth below canal stage level. The two-way travel times of the seismic-reflection profile were converted to depth by using average verticalinterval velocities assigned to three major divisions of the lithostratigraphic section imaged on the seismic-reflection profile: (1) an upper section consisting of mixed carbonates and siliciclastics from the canal bottom to the upper contact of the Arcadia Formation, (2) a middle section consisting of carbonate strata between the upper contact of the Arcadia Formation to the upper contact of the Avon Park Formation, and (3) a lower section consisting of carbonate strata from the upper contact of the Avon Park Formation to a lower part of the Avon Park Formation (fig. 13). The different average interval velocities (AIVs) shown on the west and east sides of figure 13 demonstrate their lateral variation across the seismic-reflection profile. For seismic reflections above the upper contact of the Arcadia Formation, an approximate depth scale was calculated based on the correlation of borehole data to the seismic-reflection profile. The thicknesses of the interval between the canal stage to the upper contact of the Arcadia Formation in the PB-1766 and G-2984 boreholes were divided by the one-way acoustic compressional wave travel times measured from the seismic-reflection profile for the intervals between time zero and the upper contact of the Arcadia Formation at the two wells. The average velocity for this interval is 5,569 feet per second $(\mathrm{ft} / \mathrm{s})$ in test borehole PB-1766 and 6,159 ft/s in test corehole G-2984. These AIVs are similar to interval velocities of 5,315 ft/s and $5,578 \mathrm{ft} / \mathrm{s}$ used by Cunningham and others (2001b) for vertical lithostratigraphic intervals along the Caloosahatchee River and San Carlos Bay, respectively, in southwestern Florida. For seismic reflections below the upper contact of the Arcadia Formation to the upper contact of the Avon Park Formation, an approximate depth scale was created from the sonic logs run over this stratigraphic interval in test borehole PB-1766 and much of this interval in the G-2984 test corehole. The calculated average velocity from the upper contact of the Arcadia Formation to the upper contact of the Avon Park Formation is $7,899 \mathrm{ft} / \mathrm{s}$ in test borehole PB-1766 and estimated at 6,508 ft/s in test corehole G-2984. Test borehole PB-1766 has the thickest interval of the Avon Park Formation that was logged with a sonic tool along the seismic-reflection profile. Thus, an AIV of the Avon Park Formation was produced from the Avon Park Formation sonic log values acquired in test borehole PB-1766 and used as the AIV of the Avon Park Formation across the seismic-reflection profile. The average velocity calculated for this thick interval of the Avon Park Formation is $10,030 \mathrm{ft} / \mathrm{s}$. 


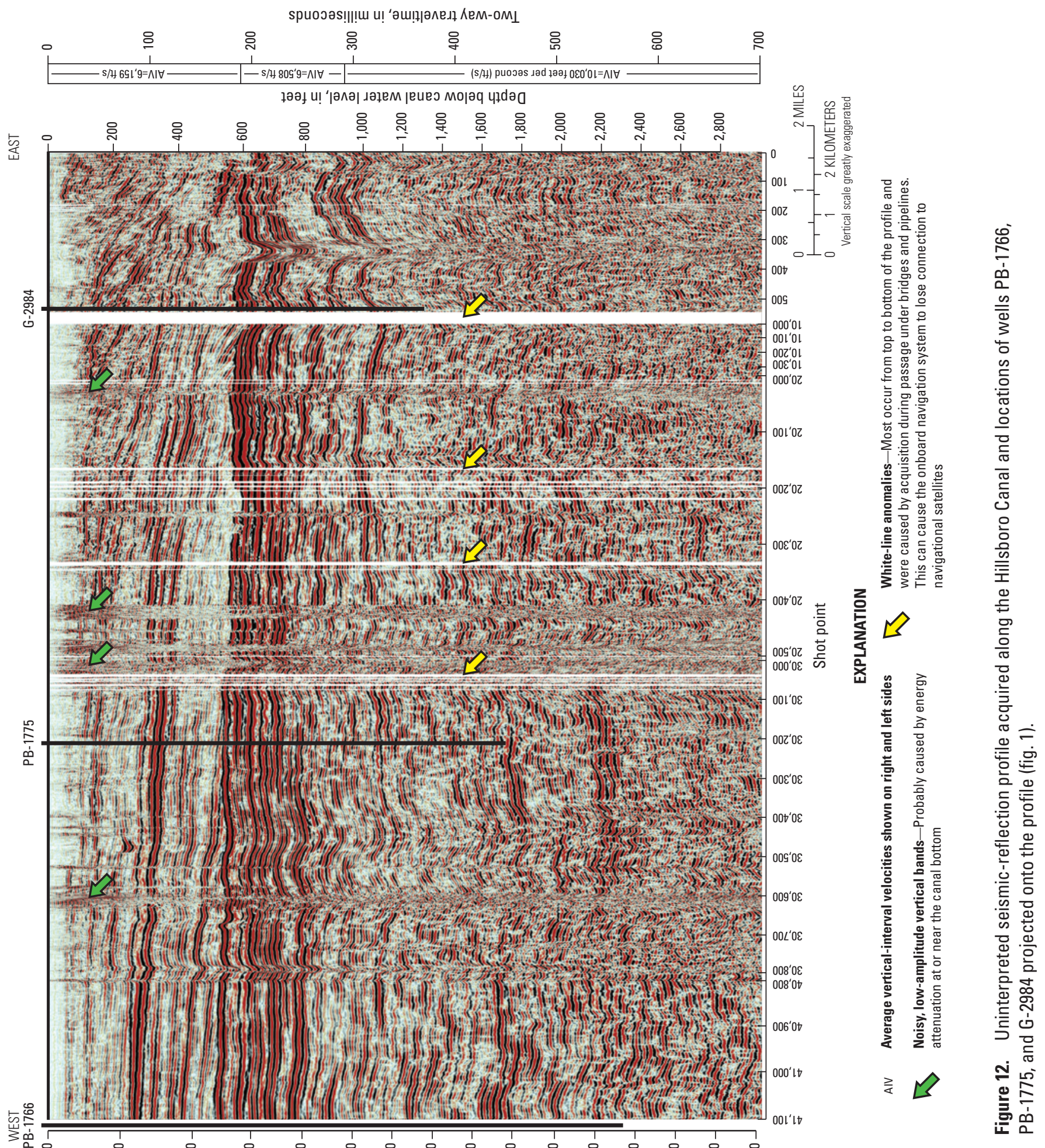

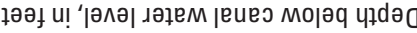

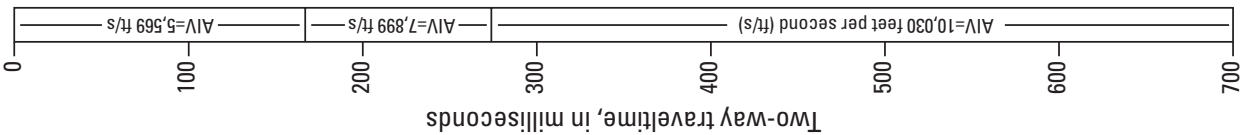




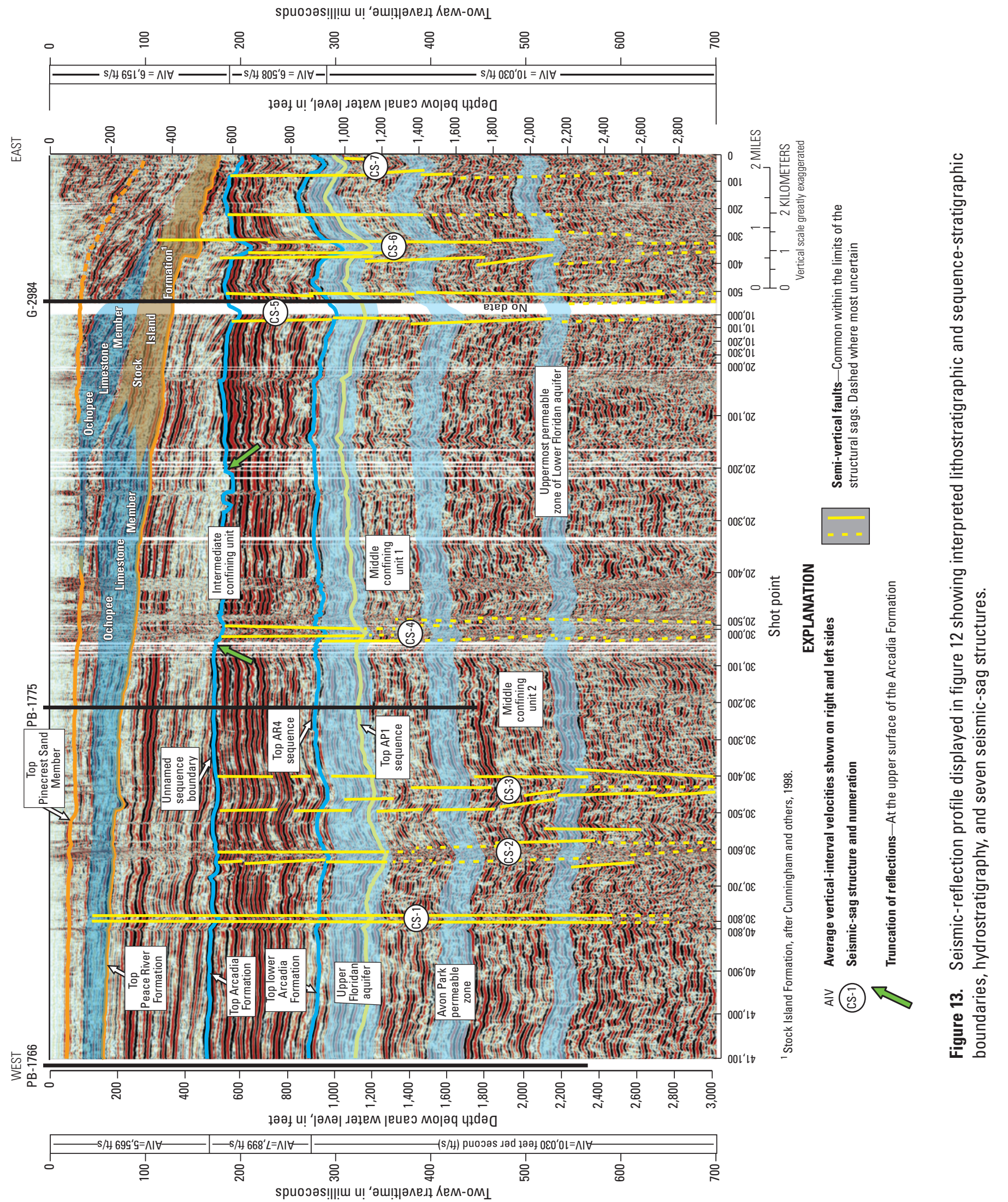


The Hillsboro Canal seismic-reflection profile (figs. 12 and 13) shows a continuous, thick, 2-dimensional profile of the major elements of the southeastern Florida middle Eocene to Pleistocene lithostratigraphic, sequence stratigraphic, and hydrogeologic record. Seismic reflections above the upper contact of the Arcadia Formation are continuous to discontinuous, with parallel to subparallel configurations that show prograding clinoform patterns having a maximum eastward apparent dip of 1.5 degrees. In the eastern part of the seismic-reflection profile, hummocky, clinoform seismic-reflection configurations are common above the Peace River Formation. Truncated reflections along a few narrow segments at the upper contact of the Arcadia Formation are indicative of karstic, erosional truncation, such as the two just west of shot point 20,200 (fig. 13, green arrows). Peace River Formation reflectors display an eastward downlap onto the upper surface contact of the Arcadia Formation across the entire profile. This downlapping relation and the truncation of reflections at the upper contact of the Arcadia Formation indicate the presence of a seismic-sequence boundary at the upper contact of the Arcadia Formation, and this seismic boundary corresponds to an unconformity and depositional sequence boundary observed in the G-2984 test corehole. The Arcadia Formation and upper and middle Avon Park Formation generally have parallel reflection configuration patterns, but also minor subparallel reflection configuration patterns and hummocky and wavy patterns. Because of the large contrast in the sonic velocity at the upper surface of the AP1 sequence, shown by the sonic $\Delta t$ curve (inverse of sonic velocity) for G-2984 (fig. 8, pl. 1), this surface is traceable on the seismic-reflection profile as a strong amplitude reflection (fig. 13). Toward the bottom of the profile, areas of hummocky reflection configurations increase, as do chaotic reflection configurations, neither of which can be reliably interpreted.

Seven narrow segments within the seismic-reflection profile contain sagging reflections that stack vertically to form seismic-sag structural systems (Cunningham and Walker, 2009). These stacked reflection sags extend upward from within the Avon Park Formation to the upper contact of the Arcadia Formation and are labeled CS-1 through CS-7 in figure 13. In some cases, they terminate within the Peace River Formation or above it. The seven seismic-sag structural systems display vertically stacked, concave-upward arrangements of generally parallel seismic-reflection patterns that commonly display an upward decrease in sag angle. Cunningham and Walker (2009) defined two types of such structural systems - narrow and broad. The difference between the two is based on the differences in their inner sag width. The inner sag width is defined as "the distance between inflection points (that is, where the shape of the subsidence profile changes from concave to convex upward) on both sides of the structural trough" (McDonnell and others, 2007). Cunningham and Walker (2009) found that in southeastern Florida beneath Biscayne Bay and the nearby Atlantic Ocean, the inner sag width of the narrow seismic-sag structural systems ranged from about $548 \mathrm{ft}$ to $2,405 \mathrm{ft}$, with a mean of $1,165 \mathrm{ft}$, and the inner sag width of the broad seismic-sag structural systems ranged from approximately $3,600 \mathrm{ft}$ to $16,000 \mathrm{ft}$, with a mean of about $8,100 \mathrm{ft}$. Six of the seven seismic-sag structural systems along the Hillsboro Canal are classified as narrow systems (average inner sag diameter of 1,844 ft), and one is classified as a broad system $(\mathrm{C}-3$, inner sag diameter of $4,730 \mathrm{ft}$ ). Local offset of seismic reflections are observed along the flanks of all seven seismic-sag structural systems and are indicative of faults associated with the sags.

The seismic-sag structural systems appear to be related to downward deformation of overlying strata into collapsed deep cave systems, as suggested by Cunningham and Walker (2009) for similar structures in southeastern Florida. The reflections on the Hillsboro Canal seismic-reflection profile generally have a chaotic configuration below the traceable depth of the seismic-sag structural systems. Therefore, the exact depths of the collapsed cave systems are not known, but they are probably deeper than the uppermost permeable zone of the Lower Floridan aquifer (fig. 13). This would place the minimum depths of the collapsed systems within the Avon Park Formation. The range in stratigraphic position of the uppermost sag for each of the seven seismic-sag structural systems is between the upper contact of the Arcadia Formation to possibly just above the upper contact of the Ochopee Limestone Member of the Tamiami Formation (fig. 13). This range suggests that collapse into paleocave systems occurred during a period that includes the Miocene and Pliocene Epochs.

Test corehole G-2984 is located within a seismic-sag structural system (fig. 13, CS-5). As discussed previously, an isolated structural low at the level of the upper contact of the Avon Park Formation at G-2984 (fig. 9) was mapped using well control only. The upper contact of the Avon Park Formation at G-2984 is as much as $80 \mathrm{ft}$ deeper than the regional trend for this mapped boundary. The reflection at the upper surface of the lower Arcadia Formation is about $50 \mathrm{ft}$ deeper to the west of G-2984, where the maximum sag on reflections in sag CS-5 is observed (fig. 13). None of the other six seismic-sag structural systems identified along the seismicreflection profile are evident on maps constructed solely on basis of the 1-dimensional, sparse well control along the canal (fig. 9). This emphasizes the value of seismic-reflection data in delineating the presence of these structural systems. Faulting and fracturing associated with these systems could provide passageways for vertical fluid flow and lead to upconing of saline water at water-supply or ASR wells in the Floridan aquifer system.

\section{Hydrogeologic Framework}

In eastern Broward County, part of the Floridan aquifer system studied herein includes the Upper Floridan aquifer, the middle semiconfining unit 1, the Avon Park permeable zone, the middle semiconfining unit 2, and the uppermost permeable zone of the Lower Floridan aquifer. The Avon 
Park permeable zone was not recognized by Miller (1986); middle semiconfining unit 1 and most of middle semiconfining unit 2 correspond to Miller's (1986) middle confining unit I. The Avon Park permeable zone also has been called the "middle Floridan aquifer" within the study area, as a unit within the Upper Floridan aquifer (Lukasiewicz, 2003). The hydrogeologic framework defined herein is consistent with that of Reese and Richardson (2008) for southern Florida.

The hydrogeologic framework of the Floridan aquifer system in eastern Broward County, from the top of the Floridan aquifer system to the bottom of uppermost permeable zone of the Lower Floridan aquifer, was constructed on the basis of analyses of borehole geophysical data, flowmeter logs, and borehole images and lithologic data, where available (pls. 1-3). Data from wells in eastern Broward County indicate the Upper Floridan aquifer, Avon Park permeable zone, and uppermost permeable zone of the Lower Floridan aquifer are present beneath and extend across this part of the county (pls. 1-3).

\section{Upper Floridan Aquifer}

The Upper Floridan aquifer is confined above by the intermediate confining unit, and below by the middle semiconfining unit 1 (fig. 2). The upper surface of the Upper Floridan aquifer is typically identified by borehole geophysical data patterns similar to those observed at G-2984, which indicate: (1) a decrease in GR activity relative to an elevated GR activity in the overlying confining unit; (2) an increase in formation resistivity as a result of a change in mineralogic composition of the aquifer and fluid properties; (3) fluctuating caliper readings indicative of an increase in megaporosity; and (4) a decrease in fluid conductivity and temperature that accompanies the increase in hydraulic conductivity (fig. 14). It was noted that the upper surface of the Upper Floridan aquifer, which is present within the lower Arcadia Formation, is distinguished by a lithology that is predominantly limestone with interspersed quartzose sandstone. These rocks are overlain by lime mudstone with intervals of clays and marls of the intermediate confining unit. The altitude of the upper surface of the Upper Floridan aquifer in the study area lies between -900 and $-1,050 \mathrm{ft}$ NGVD 29 (fig. 15).

The bottom of Upper Floridan aquifer is distinguished in the study area from the underlying middle semiconfining unit 1 by a reduction in abundance and relative contribution of flow zones identified by flowmeter analysis (fig. 14). Where flowmeter data are not available, formation resistivity, caliper, and sonic $\Delta t$ data were used to identify the bottom of the Upper Floridan aquifer. Caliper-reading fluctuations decrease toward the bottom of the Upper Floridan aquifer as enlargement of the borehole in high porosity zones decreases. Formation resistivity data collected in a few boreholes indicate a generally increasing resistivity with depth through the Upper Floridan aquifer. Sonic $\Delta t$ values were used to qualitatively identify relative changes in porosity values. Sonic $\Delta \mathrm{t}$ values greater than 120 microseconds per foot $(\mu \mathrm{sec} / \mathrm{ft})$ are estimated to indicate values of porosity greater than 42 percent. Sonic $\Delta t$ values generally decrease from the top to the bottom of the Upper Floridan aquifer, as porosity values decrease. Because the decrease in porosity values with depth is gradational, the base of the Upper Floridan aquifer has in some cases been defined as the level below which sonic $\Delta t$ values do not exceed $120 \mu \mathrm{sec} / \mathrm{ft}$. The altitude to the bottom of the Upper Floridan aquifer in the study area lies between $-1,040$ and $-1,270 \mathrm{ft}$. The thickness of Upper Floridan aquifer in the study area ranges from $40 \mathrm{ft}$ at $\mathrm{G}-2985$ (cross-section $C-C^{\prime} ; \mathrm{pl}$. 2), to $350 \mathrm{ft}$ at $\mathrm{G}-2968$ (cross sections $A-A^{\prime}$ ' and $Z-Z^{\prime}$; pls. 1 and 3) (fig. 16).

The Upper Floridan aquifer in the study area generally correlates with part of the lower Arcadia Formation, the upper Avon Park Formation, and the upper part of the upper-middle Avon Park Formation. In some cases, however, the Upper Floridan aquifer is restricted to the lower Arcadia Formation and upper Avon Park Formation (pls. 1-3). Throughout the study area, the upper surface of the Upper Floridan aquifer occurs within the lower Arcadia Formation, but in all cases below the upper surface of the lower Arcadia Formation (pls. 1-3). The bottom of the Upper Floridan aquifer generally occurs within the upper-middle Avon Park Formation, although it may correlate with the upper surface of the upper-middle Avon Park Formation or occurs within the upper Avon Park Formation in the southwestern part of the study area (cross section $C-C^{\prime}$, pl. 2). At G-2984, the upper surface of the Upper Floridan aquifer occurs within the AR3 sequence of the lower Arcadia Formation, and the bottom of the Upper Floridan aquifer is positioned within the AP1 sequence of the upper-middle Avon Park Formation (fig. 14).

Transmissivity of the Upper Floridan aquifer generally increases from west to east across the study area (fig. 17), and ranges from 120 to 31,000 feet squared per day $\left(\mathrm{ft}^{2} / \mathrm{d}\right.$; appendix table 1-6). The anomalously low value at CS-I2 $\left(120 \mathrm{ft}^{2} / \mathrm{d}\right)$ may be the result of testing only two zones totaling $80 \mathrm{ft}$ of the entire $240 \mathrm{ft}$ thickness of the Upper Floridan aquifer at that location.

Flowmeter data were collected in most of the boreholes used to define the hydrogeologic framework in the study area. Generally, multiple flow zones are present in the Upper Floridan aquifer, and these zones are on the scale of $1 \mathrm{ft}$ to tens of feet thick. Fifteen flow zones were identified in G-2984 using spinner flowmeter analysis and oscillations or changes in fluid conductivity and temperature values (fig. 14). A thin flow zone that contributes substantial flow into the borehole occurs at the upper surface of the Upper Floridan aquifer in G-2984. A group of four thin flow zones occurs within the middle of the Upper Floridan aquifer, and collectively contribute almost one third of the total flow from the aquifer into the borehole. This group of four flow zones occurs in the lower part of the upper Avon Park Formation and in the upper part of the AP1 sequence.

The occurrence and thicknesses of flow zones below the top of the AP1 sequence within the Upper Floridan aquifer decrease to the west (pls. 1 and 2; figs. 6 and 7). Flow zones within this interval are not indicated by flowmeter 


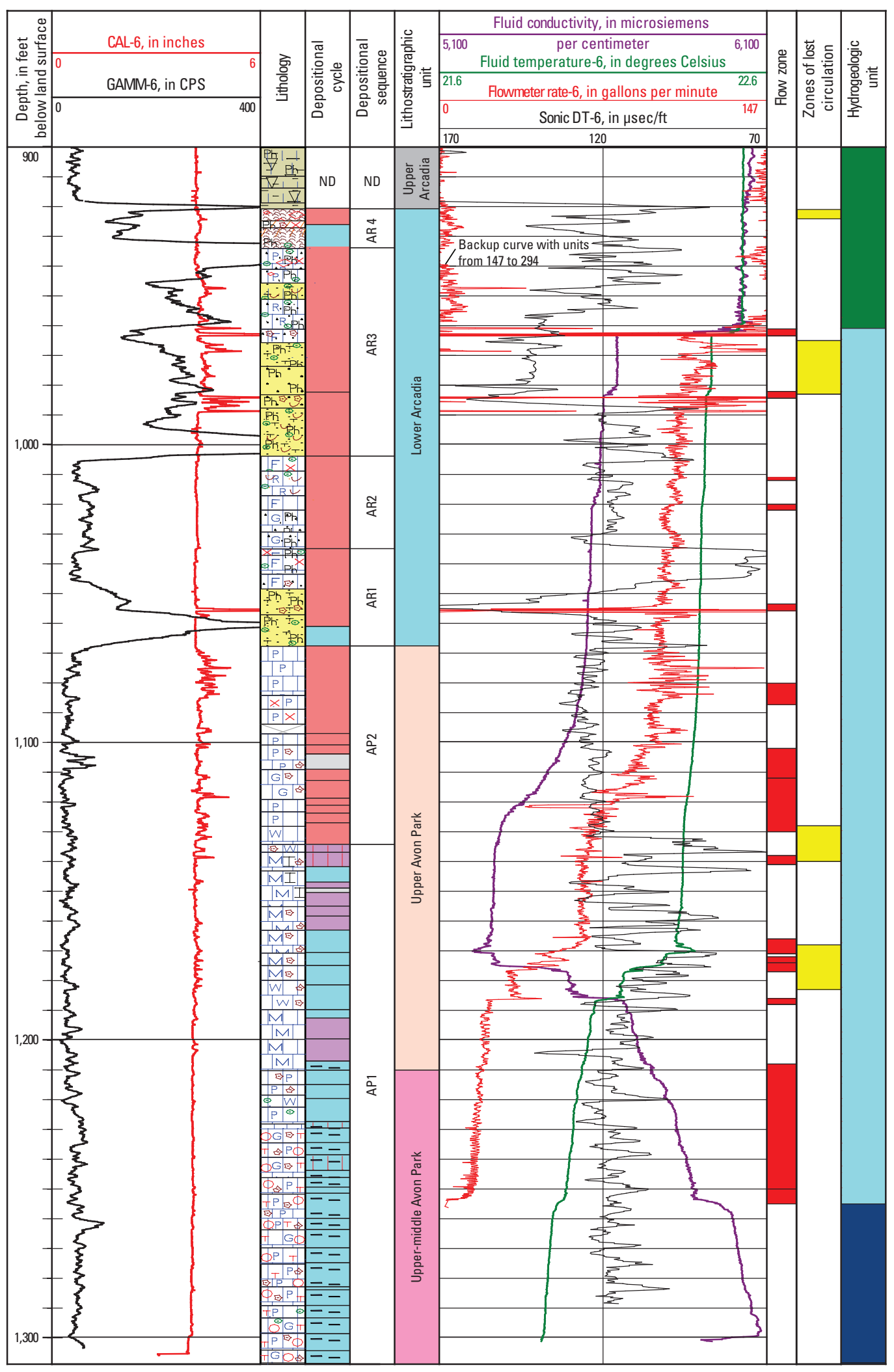

Figure 14. Borehole geophysical data including fluid properties and flowmeter logs, lithology, hydrogeologic units, and flow zones for test corehole G-2984. 


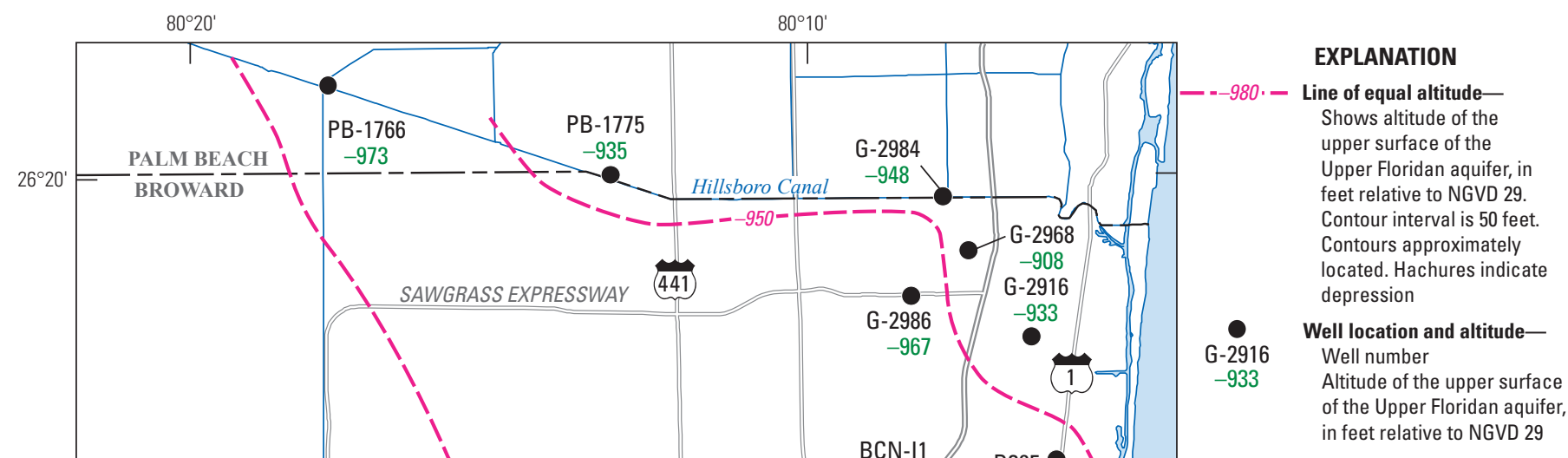




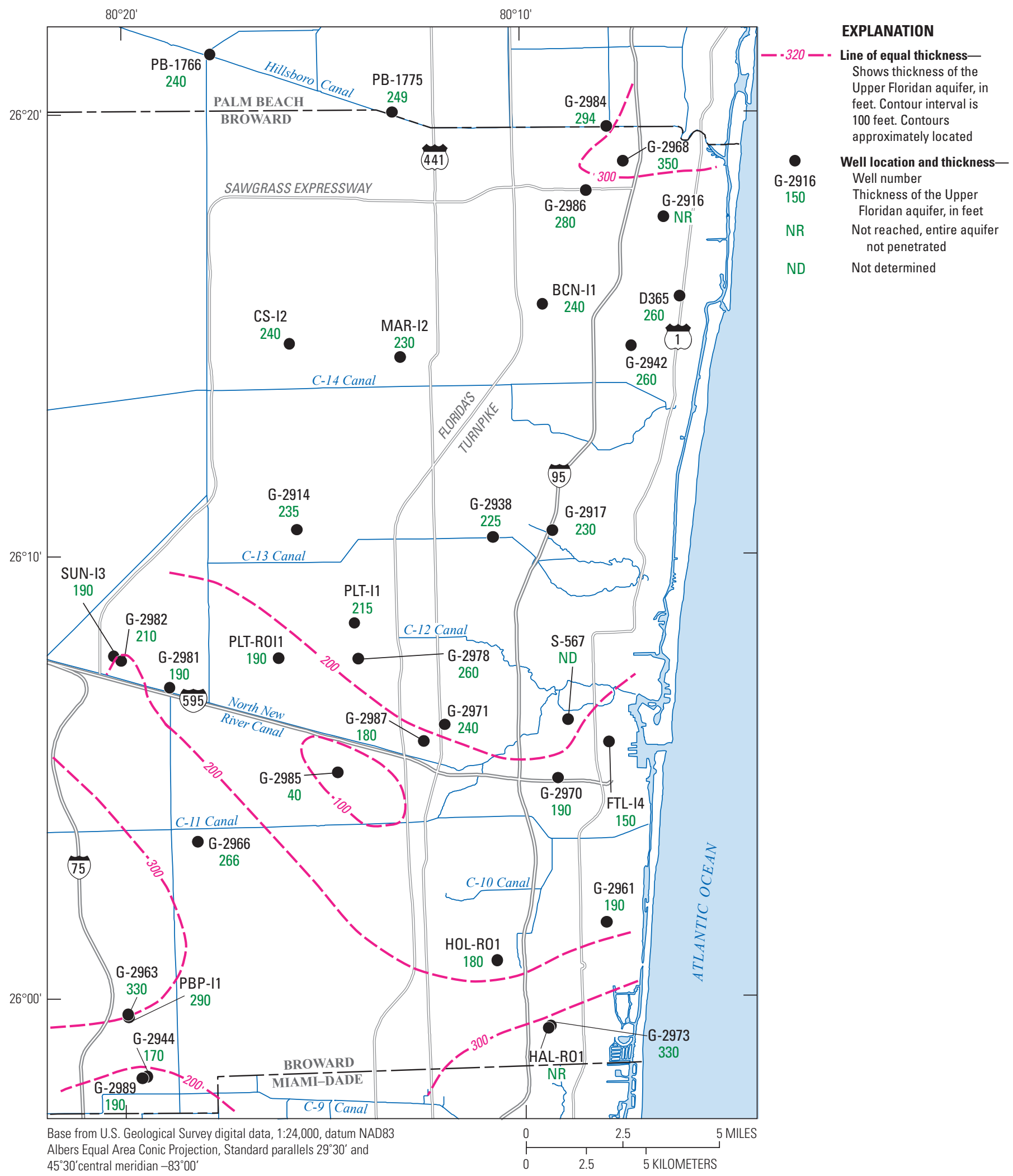

Figure 16. Thickness of the Upper Floridan aquifer. 


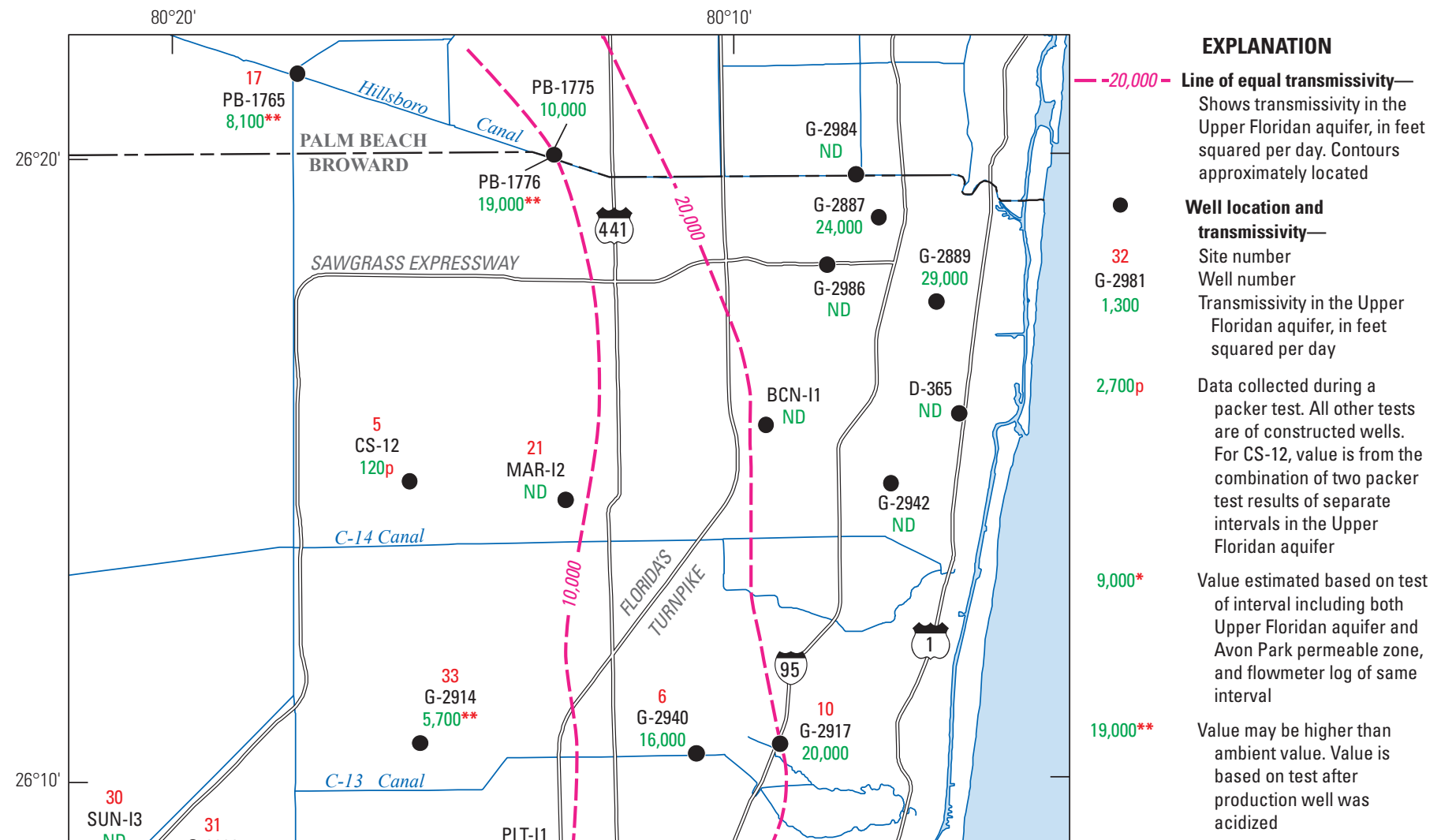

No data 
measurements in some wells to the west, including SUN-I3, PLT-ROI1, and G-2985 (pl. 2), and only one or two thin (less than $10 \mathrm{ft}$ ) flow zones are indicated in three other wells (G-2981, pl. 2; CS-I2, fig. 6; G-2945, fig. 7). In contrast, to the east, below the top of the AP1 sequence in the Upper Floridan aquifer, seven flow zones with a combined thickness of $60 \mathrm{ft}$ are indicated in G-2984 (fig. 14), and four flow zones, also with a combined thickness of $60 \mathrm{ft}$, are indicated by the flowmeter data in G-2968 (pl. 1). Although the overlying AP2 sequence thickens to the west, there is only one thin flow zone, associated with the upper contact of the Avon Park Formation, present in some wells.

\section{Middle Semiconfining Unit 1}

The middle semiconfining unit 1 separates the overlying Upper Floridan aquifer from the underlying Avon Park permeable zone. In the study area, the altitude of the top of the middle semiconfining unit 1 ranges from $-1,040 \mathrm{ft}$ to $-1,270 \mathrm{ft}$ NGVD 29, and the altitude at the bottom range from $-1,350 \mathrm{ft}$ to $-1,630 \mathrm{ft}$ NGVD 29 . The thickness ranges across the study area from $150 \mathrm{ft}$ to about $500 \mathrm{ft}$. Where hydraulic conductivity has been estimated, values range from 0.9 to 19 feet per day (ft/d) (table 4). Flow zones are indicated (by flowmeter measurements) in some wells in the study area (pls. 1-3), but these few flow zones typically contribute less to overall flow than the flow zones in the aquifer units of the Floridan aquifer system.

\section{Avon Park Permeable Zone}

The Avon Park Permeable Zone is identified by an increase in the number and spatial density of flow zones relative to overlying and underlying confining units, as indicated by changes in vertical borehole fluid flow in flowmeter measurements and by zones of decreased and more pronounced fluctuations in sonic $\Delta \mathrm{t}$ values, which indicate zones of greater and lesser porosity

Table 4. Horizontal hydraulic conductivity values for major permeable zones and semiconfining units based on data from aquifer and packer tests in the study area.

[APPZ, Avon Park permeable zone; LF1, uppermost major permeable zone of the Lower Floridan aquifer; $\mathrm{MC} 1$, middle semiconfining unit; $\mathrm{MC} 2$, middle semiconfining unit 2; UFA, Upper Floridan aquifer]

\begin{tabular}{lcccc}
\hline $\begin{array}{c}\text { Permeable } \\
\text { zone or } \\
\text { semi-confin- } \\
\text { ing unit }\end{array}$ & $\begin{array}{c}\text { Minimum } \\
\text { value } \\
\text { (feet/day) }\end{array}$ & $\begin{array}{c}\text { Maximum } \\
\text { value } \\
\text { (feet/day) }\end{array}$ & $\begin{array}{c}\text { Median } \\
\text { (feet/day) }\end{array}$ & $\begin{array}{c}\text { Number } \\
\text { of tests }\end{array}$ \\
\hline UFA & 1.4 & 200 & 80 & 20 \\
MC1 & 0.9 & 19 & 3 & 6 \\
APPZ & 1 & 170 & 16 & 17 \\
MC2 & 0.02 & 66 & 1 & 62 \\
LF1 & 1.2 & 708 & 94 & 5 \\
\hline
\end{tabular}

(pls. 1-3). The top of this zone is estimated to range from $-1,350$ to $-1,630 \mathrm{ft}$ NGVD 29 (fig. 18) and the bottom from $-1,500$ to $-1,710 \mathrm{ft}$ NGVD 29 in the study area. The thickness is estimated to range from 35 to $210 \mathrm{ft}$ (fig. 19). The Avon Park permeable zone generally occurs within the upper part of the lower-middle Avon Park Formation (pls. 1-3).

Estimated transmissivity of the Avon Park permeable zone in the study area ranges from 900 to $10,000 \mathrm{ft}^{2} / \mathrm{d}$ (fig. 20, appendix table 1-6) for selected sites. The summed length of the tested interval for selected sites was generally greater than $50 \mathrm{ft}$. Additionally, where tested intervals included both the Upper Floridan aquifer and Avon Park permeable zone an estimate of transmissivity for each zone was made. The estimated hydraulic conductivity of the Avon Park permeable zone in the study area ranges from about 1 to $170 \mathrm{ft} / \mathrm{d}$ (table 4).

\section{Middle Semiconfining Unit 2}

The middle semiconfining unit 2 separates the overlying Avon Park permeable zone from the underlying uppermost permeable zone of the Lower Floridan aquifer, and can be recognized by a lower density of flow zones and less pronounced fluctuations in sonic $\Delta \mathrm{t}$ values than in the overlying Avon Park permeable zone (pls. 1-3). The altitude of the top of middle semiconfining unit 2 ranges from about $-1,500 \mathrm{ft}$ to $-1,710 \mathrm{ft}$ NGVD 29 , and the base from $-1,970 \mathrm{ft}$ to $-2,250 \mathrm{ft}$ NGVD 29 in the study area. The thickness varies across the study area from $340 \mathrm{ft}$ to about $670 \mathrm{ft}$ (appendix table 1-5). Estimated hydraulic conductivity values range from 0.02 to $66 \mathrm{ft} / \mathrm{d}$ (table 4). Productive flow zones are indicated by flowmeter measurements in some wells, for example wells G-2971 and BCN-I1 (pls. 2 and 3), but the unit is considered to be semiconfining.

\section{Uppermost Permeable Zone of the Lower Floridan Aquifer}

The Lower Floridan aquifer is identified by the presence of an increased number and spatial density of flow zones relative to overlying middle semiconfining unit 2, as indicated by flowmeter data; by zones of decreased and more pronounced fluctuations in sonic $\Delta \mathrm{t}$ values, indicating zones of increased and decreased porosity (pls. 1-3); and by caliper curves with thin, abrupt, increases in borehole diameter values indicating zones of fracturing, or thin intervals of megaporosity. The altitude of the upper surface of uppermost permeable zone of the Lower Floridan aquifer is estimated to range from $-1,970$ to $-2,250 \mathrm{ft}$ NGVD 29 and the lower surface from $-2,100$ to $-2,320 \mathrm{ft}$ NGVD 29 in the study area (appendix table 1-5). The thickness is estimated to range from 50 to $190 \mathrm{ft}$. The uppermost permeable zone of the Lower Floridan aquifer corresponds to the lower Avon Park Formation (pls. 1-3). Transmissivity ranges from 61 to greater than $35,000 \mathrm{ft}^{2} / \mathrm{d}$ (appendix table 1-6). Estimates of hydraulic conductivity range from 1.2 to $708 \mathrm{ft} / \mathrm{d}$ (table 4). Flowmeter analysis indicates the presence of one or more flow zones in the uppermost permeable zone of the Lower Floridan aquifer. 


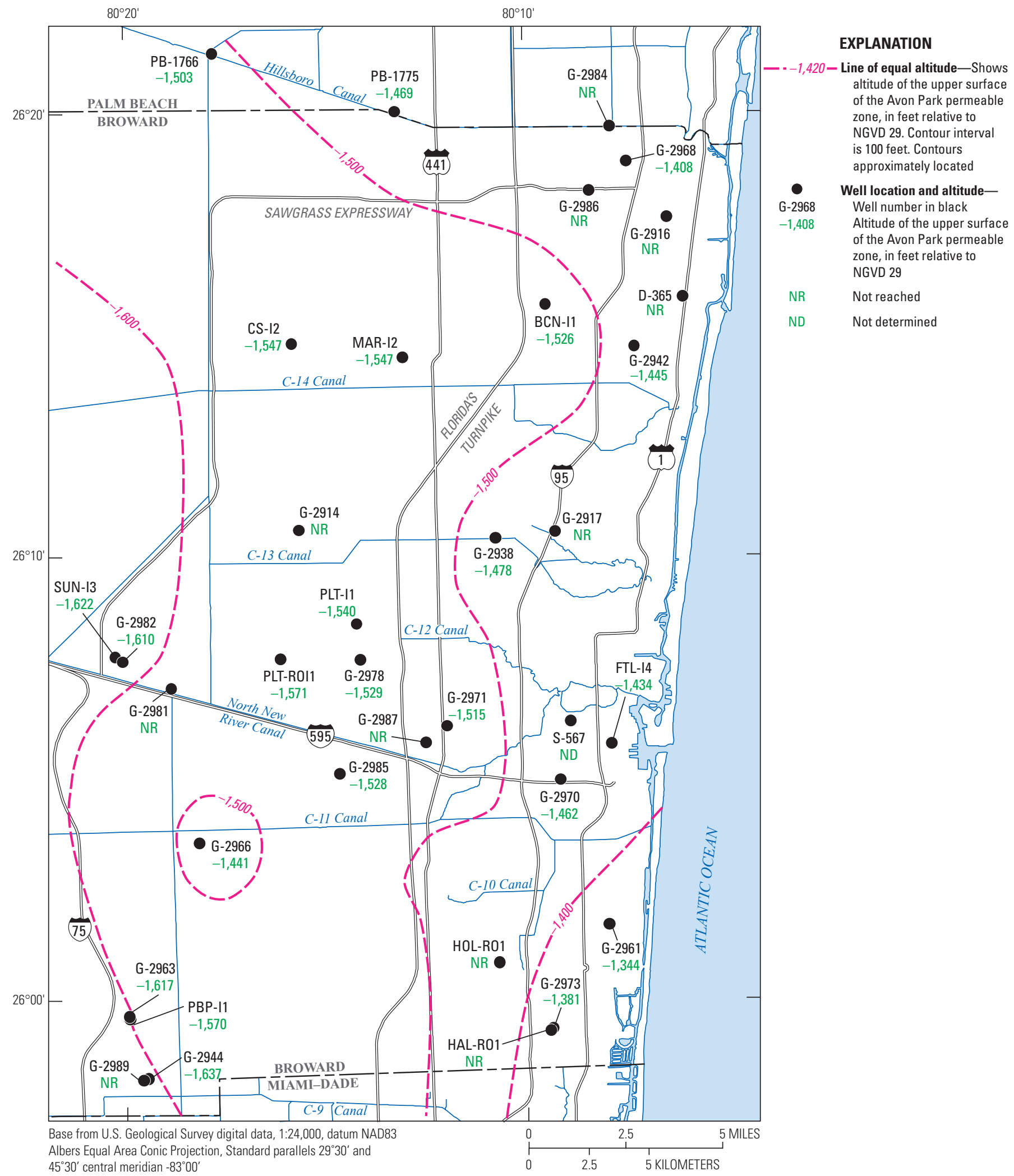

Figure 18. Altitude of the upper boundary of the Avon Park permeable zone. 


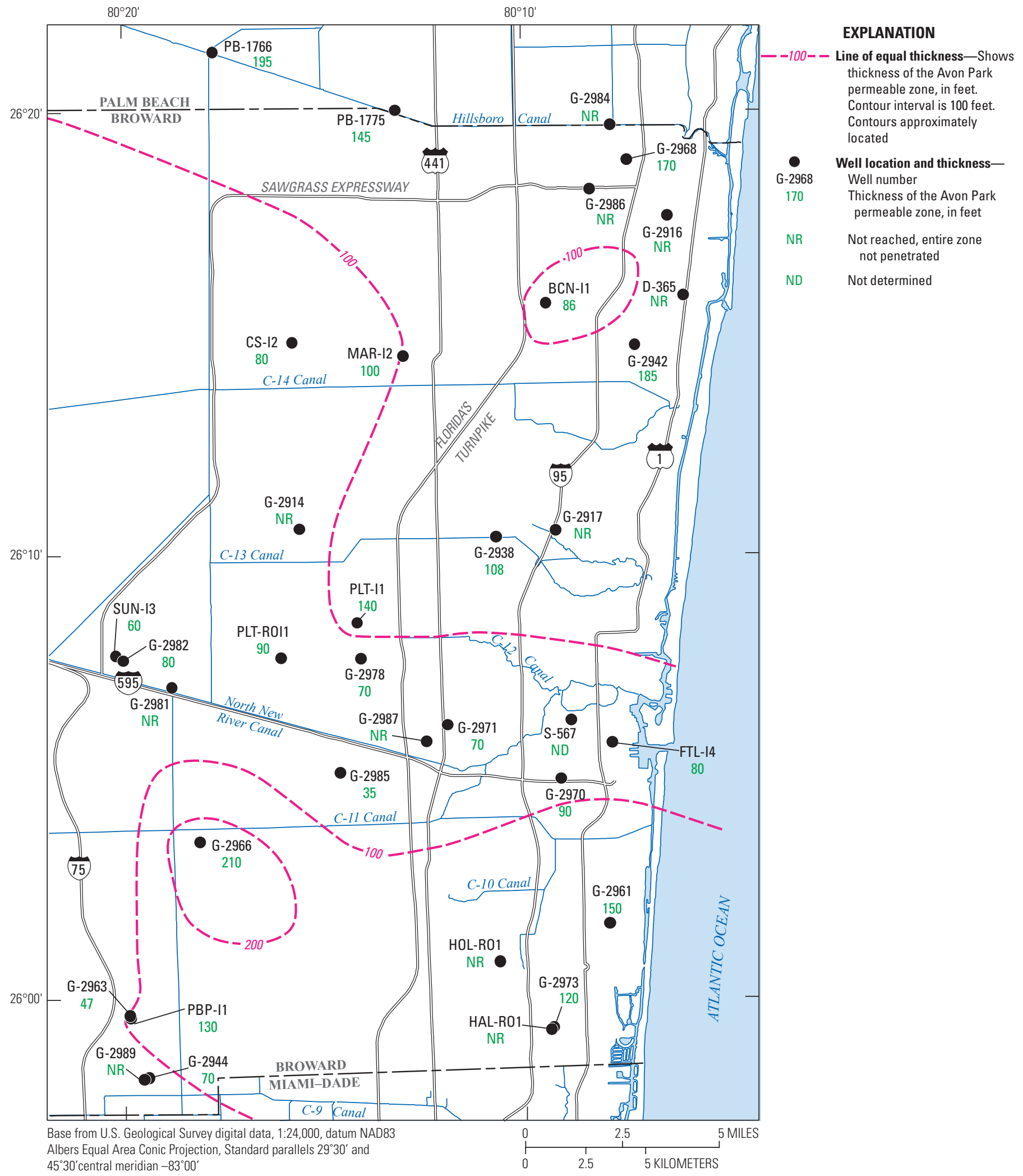

Figure 19. Thickness of the Avon Park permeable zone. 


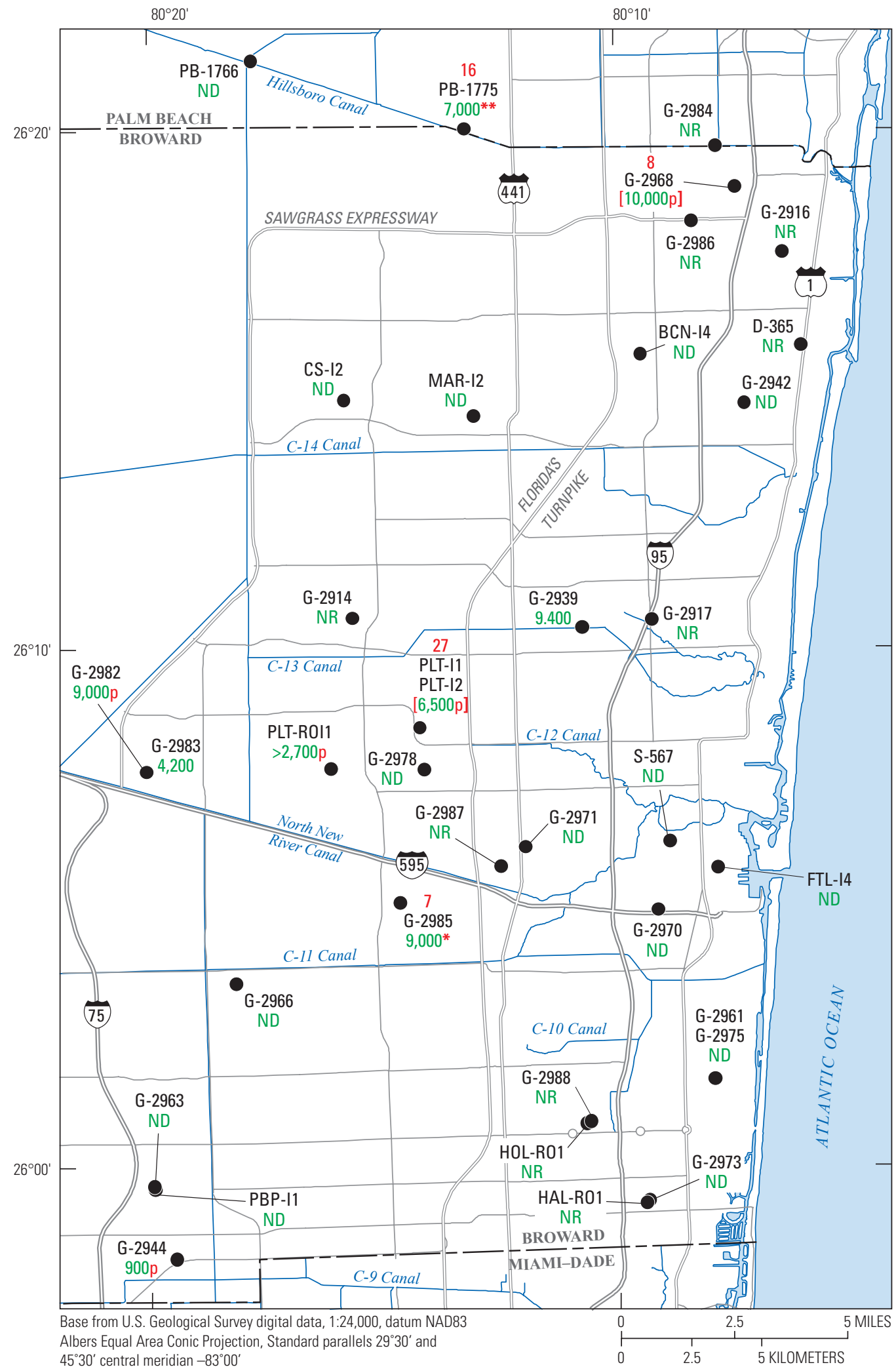

EXPLANATION

- Well-

8 Site number

G-2968 Well number

10,000 Transmissivity in Avon Park permeable zone, in feet squared per day

ND No data or tested interval of insufficient length

NR Not reached, zone not penetrated

10,000p Data collected during packer test, all other tests are of constructed well intervals

9,000* Value estimated based on test of interval including both Upper Floridan aquifer and Avon Park permeable zone, and flowmeter log of same interval

7.000** Value estimated based on test of Upper Floridan aquifer and flowmeter log of open interval including both Upper Floridan aquifer and Avon Park permeable zone

$[10,000]$ Value estimated based on combining transmissivity values of two tests of separate intervals in a well or in two wells at a site

Figure 20. Distribution of transmissivity of the Avon Park permeable zone. 


\section{Conceptualization of Groundwater Flow Within the Floridan Aquifer System}

One goal for this study is to develop an improved understanding of geologic features that influence groundwater flow within the Floridan aquifer system in the study area. Theoretically, the lithologic attributes of the pore network can be characterized within the context of the cyclostratigraphic framework, and this provides valuable information on the heterogeneous distribution of porosity and permeability to inform groundwater management of the Floridan aquifer system. This report provides an integrated analysis of available borehole-geophysical, seismic-reflection, and lithologic data. Core samples from the G-2984 test corehole were macroscopically and microscopically examined to characterize the relation between rock depositional textures, associated pore networks, and borehole geophysical log data, especially digital optical and acoustic borehole images, and borehole flowmeter data. The result is a preliminary conceptual model of groundwater flow in the Floridan aquifer system in Broward County.

Water-bearing carbonate rocks of the Floridan aquifer system exhibit considerable groundwater exchange between a matrix porosity and vuggy porosity (Martin and Screaton, 2001). The porosity of this system has been described as a dual-continuum, providing both diffuse and concentrated groundwater flow that is hydraulically interconnected (Vacher and Mylroie, 2002; Budd and Vacher, 2004; Screaton and others, 2004). Diffuse groundwater flow can occur in a carbonate rock within which the pore system consists mostly by interparticle, interparticle, intercrystalline, and separate-vug pore space. Concentrated groundwater flow likely occurs within carbonate rock with a pore system characterized by touching-vug pores. In the Floridan aquifer system, this type of vuggy pore space is mainly interconnected vuggy megapores (for example bedding-plane vugs), vertical fractures, tectonic faults, and extensional faults related to karst collapse.

The Upper Floridan aquifer at the G-2984 test corehole corresponds to the lower Arcadia Formation, upper Avon Park Formation, and upper-middle Avon Park Formation in the depth interval from about 960 to 1,255 ft bls (figs. 8 and 14, and pl. 1), and contains both diffuse and concentrated groundwater flow zones. Different types of flow zones are indicated by core, thin section, flowmeter, and borehole-wall image data. The Upper Floridan aquifer is overlain by rocks of the upper part of the lower Arcadia Formation, which consist of lowpermeability floatstone and rudstone, and quartz sandstone.

The upper surface of the Upper Floridan aquifer in the G-2984 corehole is marked by a thin, approximately $2 \mathrm{ft}$-thick flow zone between about 960 and $964 \mathrm{ft}$ bls. This flow zone is formed by two open bedding-plane vugs. Concentrated groundwater flow into the borehole through this zone is demonstrated by an abrupt vertical increase in borehole fluid flow that was detected by a spinner flowmeter (fig. 21). From about 955 to $962 \mathrm{ft}$ bls, bryozoan floatstone composes the lower Arcadia Formation.
Diffuse flow in the Upper Floridan aquifer is recognized in the interval from about 1,102 to $1,130 \mathrm{ft}$ bls in the G-2984 test corehole (interval shown is 1,102 to $1,115 \mathrm{bls}$; fig. 22). The rock of this flow zone is mostly a benthic foraminifera grain-dominated packstone. A benthic foraminifera, peloid, skeletal fragment, grain-dominated packstone and grainstone was observed in an acid-etched limestone core sample and accompanying thin section acquired from about $1,110 \mathrm{ft}$ bls (fig. 23). The dominant pore type at this depth is interparticle porosity. Interparticle porosity of the $1,109.5 \mathrm{ft}$ sample is between 20 and 35 percent, based on a visual estimate from the thin section. A gradual, rather than abrupt, upward increase in borehole fluid-flow velocity measured by the spinner flowmeter in the interval from 1,105 to 1,115 bls indicates diffuse groundwater flow, which is corroborated by the observed pore types in core samples and thin section.

Both diffuse and concentrated groundwater flow occurs between approximately 1,166 and $1,177 \mathrm{ft}$ bls in the G-2984 test corehole as indicated by optical and acoustic images, spinner flowmeter, borehole-fluid temperature and conductivity data (fig. 24). The diffuse flow is associated with mostly interparticle and particle-moldic pore types in grain-dominated packstone and grainstone, whereas concentrated flow is associated with vuggy megaporosity in micrite-dominated limestone that is mainly mudstone and wackestone. Three flow zones are present within this $10 \mathrm{ft}$ interval of the Avon Park Formation. The upper flow zone (at approximately 1,166-1,171 ft bls) has a depositional texture characterized by moldic, benthic foraminifera, mud- to grain-dominated packstone and grainstone. Moldic and interparticle porosity provide for diffuse groundwater flow within this grain-dominated limestone. Two lower flow zones (at approximately 1,171 to $1,174 \mathrm{ft}$ bls and 1,175 to $1,177 \mathrm{ft}$ bls) were identified by the observation of vuggy megaporosity on borehole images, and the association of the megaporosity with increases in vertical borehole fluid flow velocities measured by a spinner flowmeter. These two flow zones have a depositional texture characterized by particlemoldic, benthic-foraminifera, mudstone and wackestone, and mud-dominated packstone. The vuggy megaporosity in these two zones is mostly semi-vertically oriented and centimeterscale in diameter.

Although core-sample data are not widely available for the flow zones identified with borehole geophysical data, inferences regarding the nature of groundwater flow into or out of other wells could be made on the basis of the flowmeter measurements. For example, a concentrated flow zone is inferred in the G-2940 test corehole (fig. 25) by comparing spinner flowmeter data to pore network types that were observed on digital optical images. The flow zone is present in the lower Arcadia Formation and is approximately $1 \mathrm{ft}$ thick (from about 1,027 to 1,028 ft bls). Evidence indicates groundwater flow is into the borehole through a bedding-plane vug (fig. 26). A similar type of flow zone is observed in data from the PB-1775 well (from about 1,040 to 1,060 ft bls) in the lowermost part of the Arcadia Formation (fig. 4). Although these flow zones and a minor flow zone in $\mathrm{G}-2984$ between 


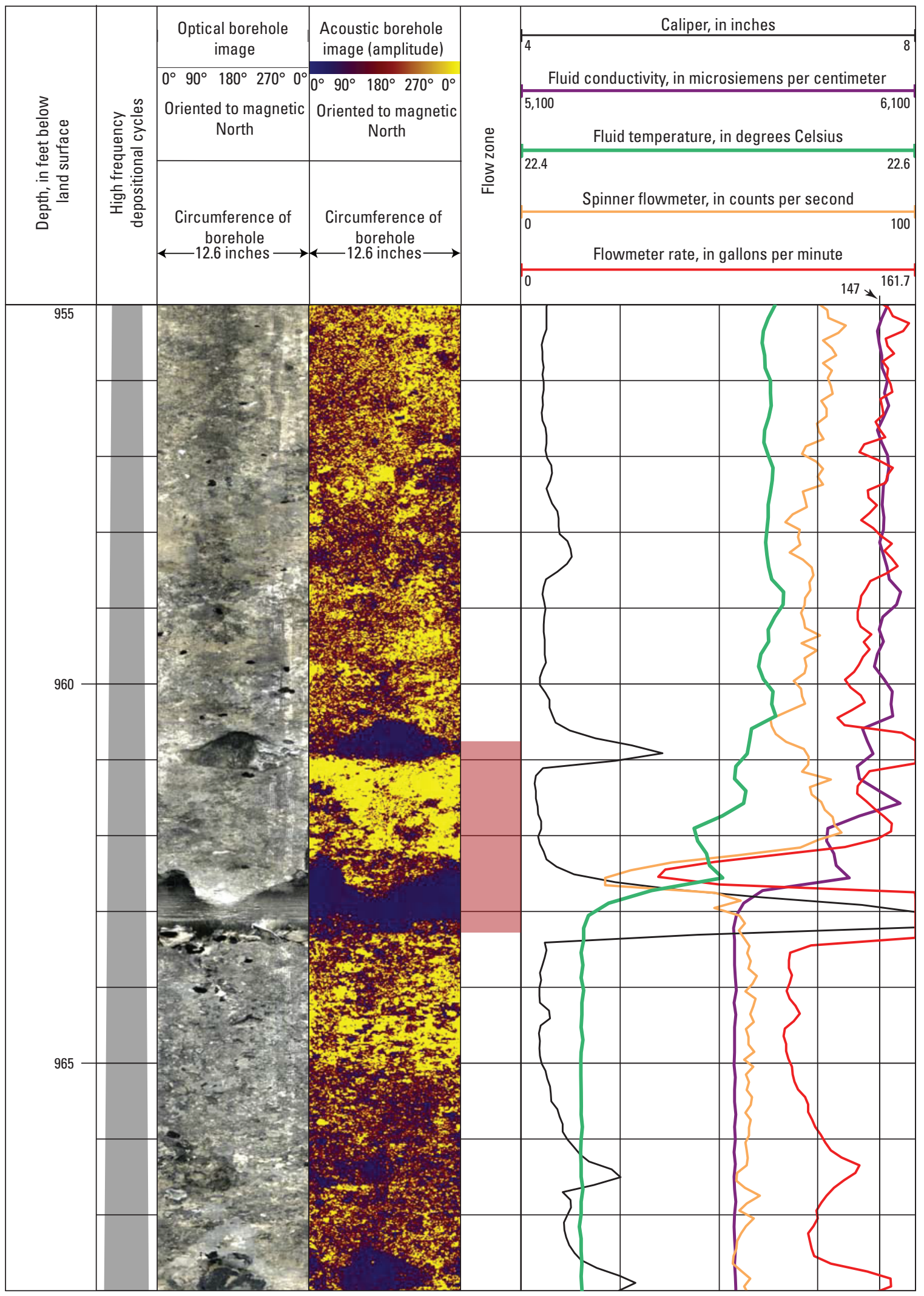

Figure 21. Borehole geophysical log data for test corehole G-2984, from 955 to 968 feet below land surface (ft bls), including optical and acoustic images, flowmeter and fluid properties, flow zones, and relation to high frequency depositional cycles. 


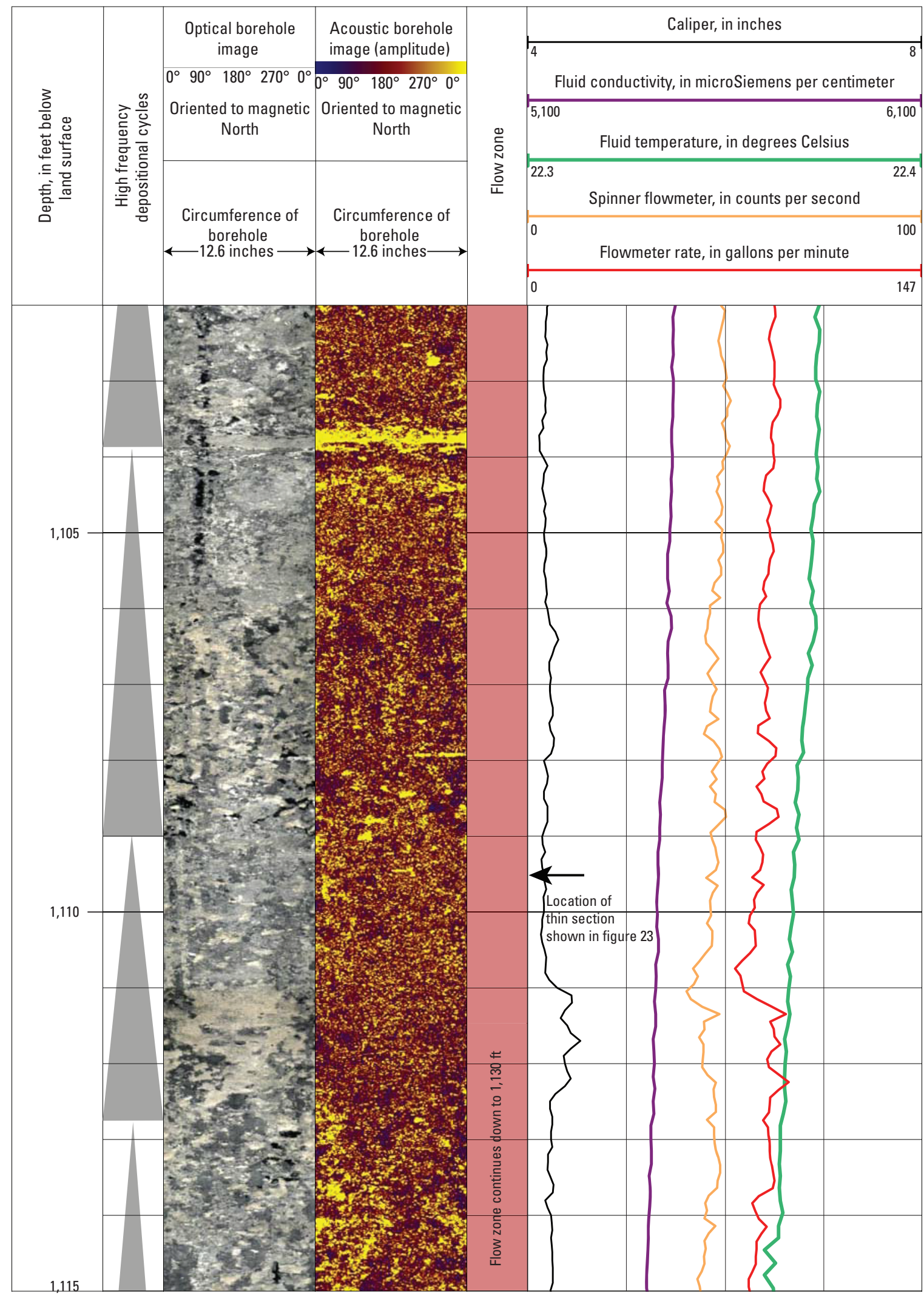

Figure 22. Borehole geophysical log data for test corehole G-2984, from 1,102 to 1,115 feet below land surface ( $\mathrm{ft}$ bls), including optical and acoustic images, flowmeter and fluid properties, flow zones, and relation to high frequency depositional cycles. 

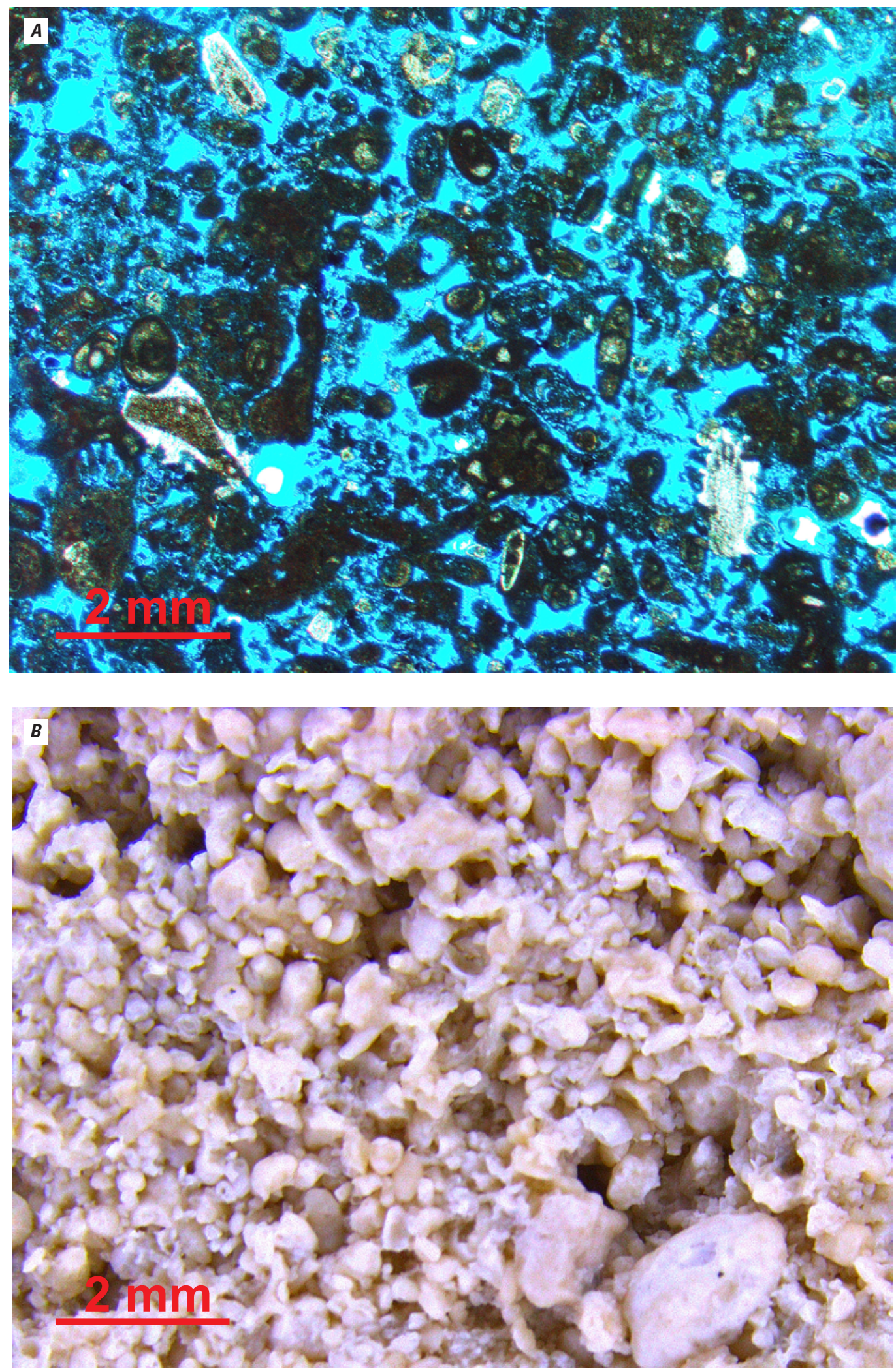

Figure 23. Microscopic images of G-2984 at 1,109.45 feet below land surface ( $\mathrm{ft}$ bls). (A) Thin-section: depositional texture is a small benthic foraminifer, peloid, skeletal fragment grainstone and graindominated packstone with mainly interparticle porosity; $(B)$ photograph of acid-etched, slabbed, core sample: depositional texture is a small benthic foraminifera, peloid, skeletal fragment grainstone and grain-dominated packstone with mainly interparticle porosity. 


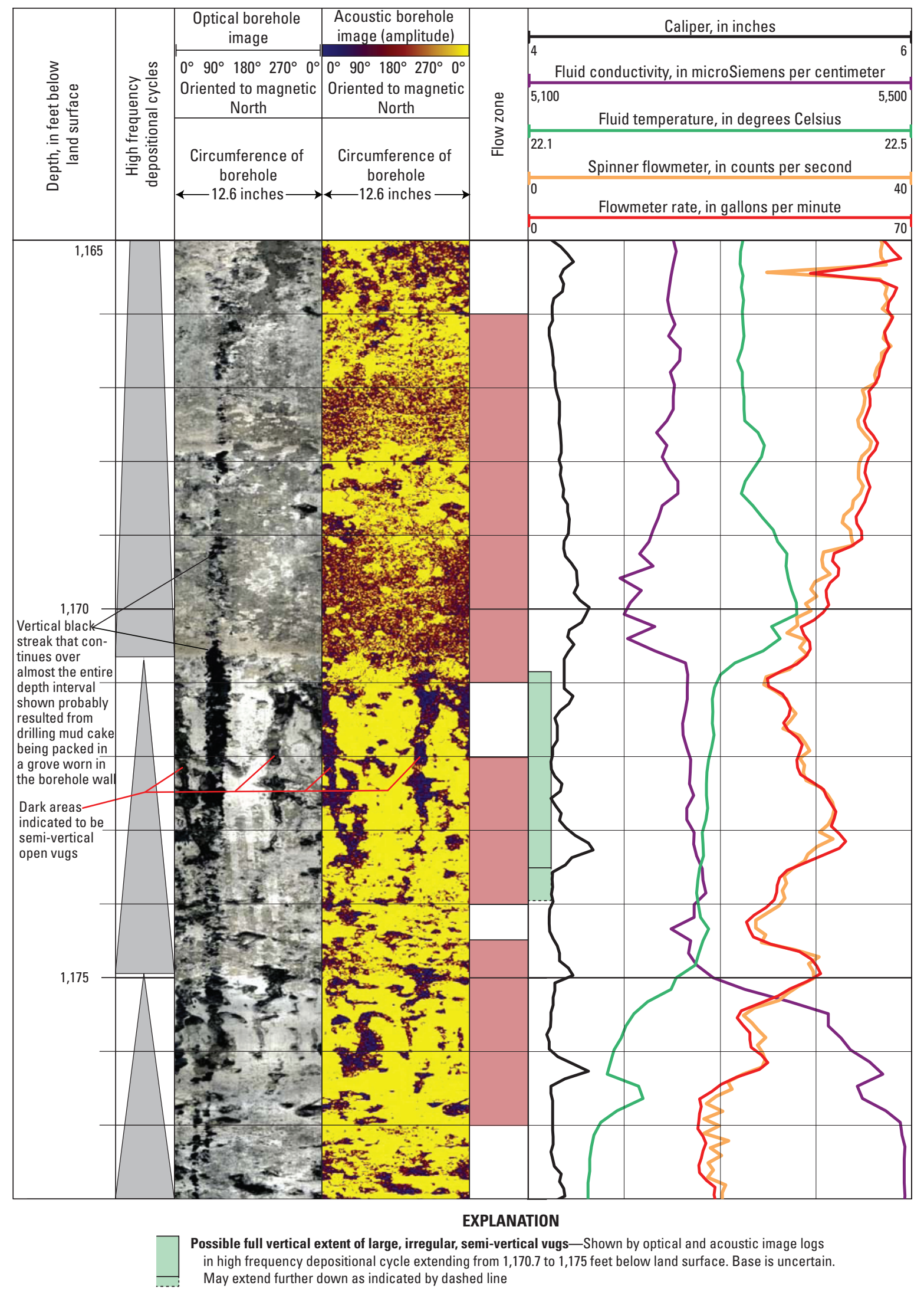

Figure 24. Borehole geophysical log data for test corehole G-2984, from 1,165 to 1,178 feet below land surface (ft bls), including optical and acoustic image, flowmeter and fluid properties, flow zones, and relation to high frequency depositional cycles. 


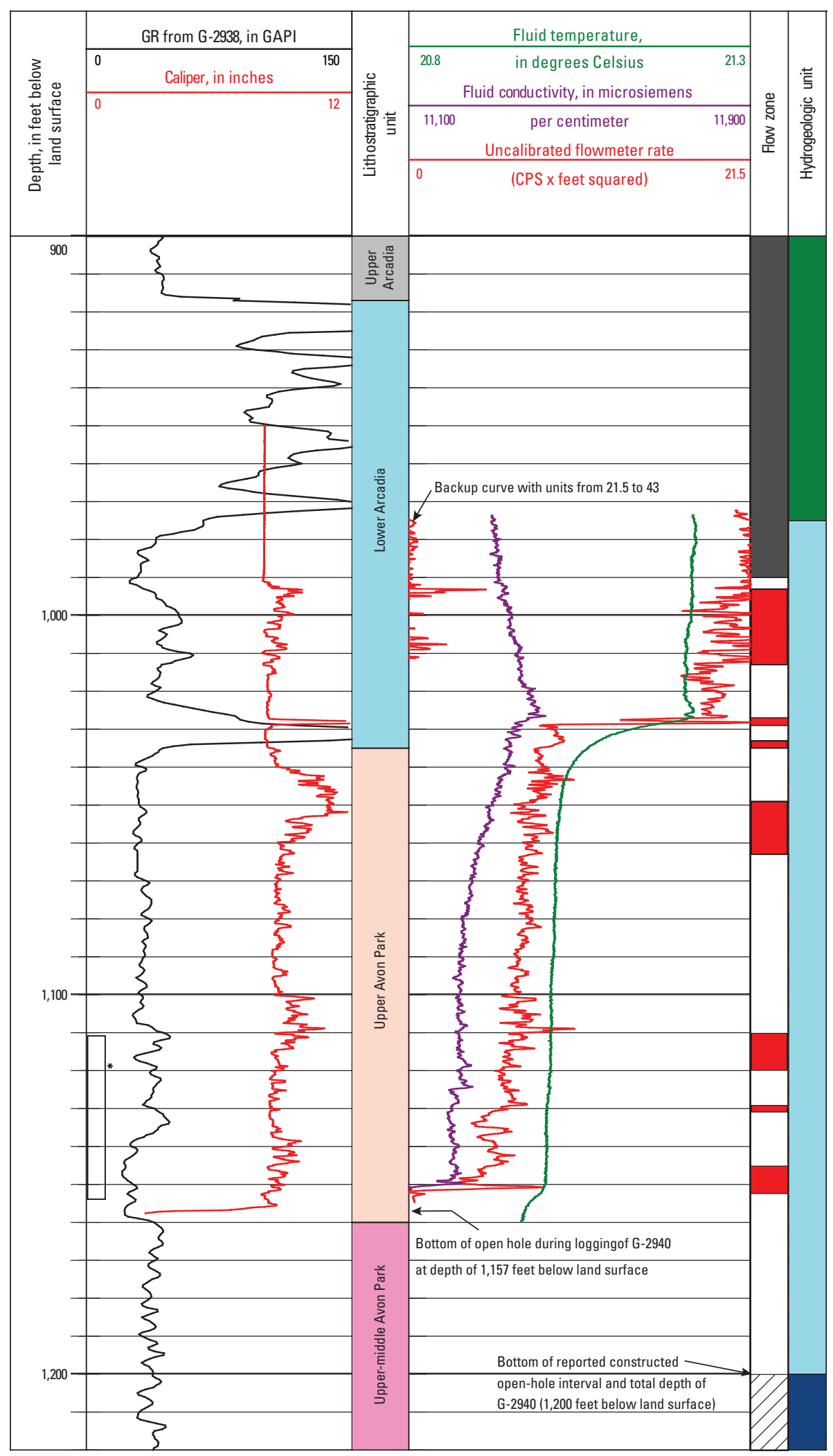

* Grout filling large vugs in borehole wall in this interval observed in optical borehole image data and may have reduced flow from flow zones during logging. Pressure grouting of casing set through this interval in a nearby well (G-2939) at the site may have caused intrusion of grout into the area of this well.

Figure 25. Borehole geophysical log data, including fluid properties and flowmeter log data, hydrogeologic units, and flow zones, for monitoring well G-2940 at site 6, from 900 to 1,220 feet below land surface ( $\mathrm{ft}$ bls). Flowmeter data were corrected for borehole size using caliper log data. 


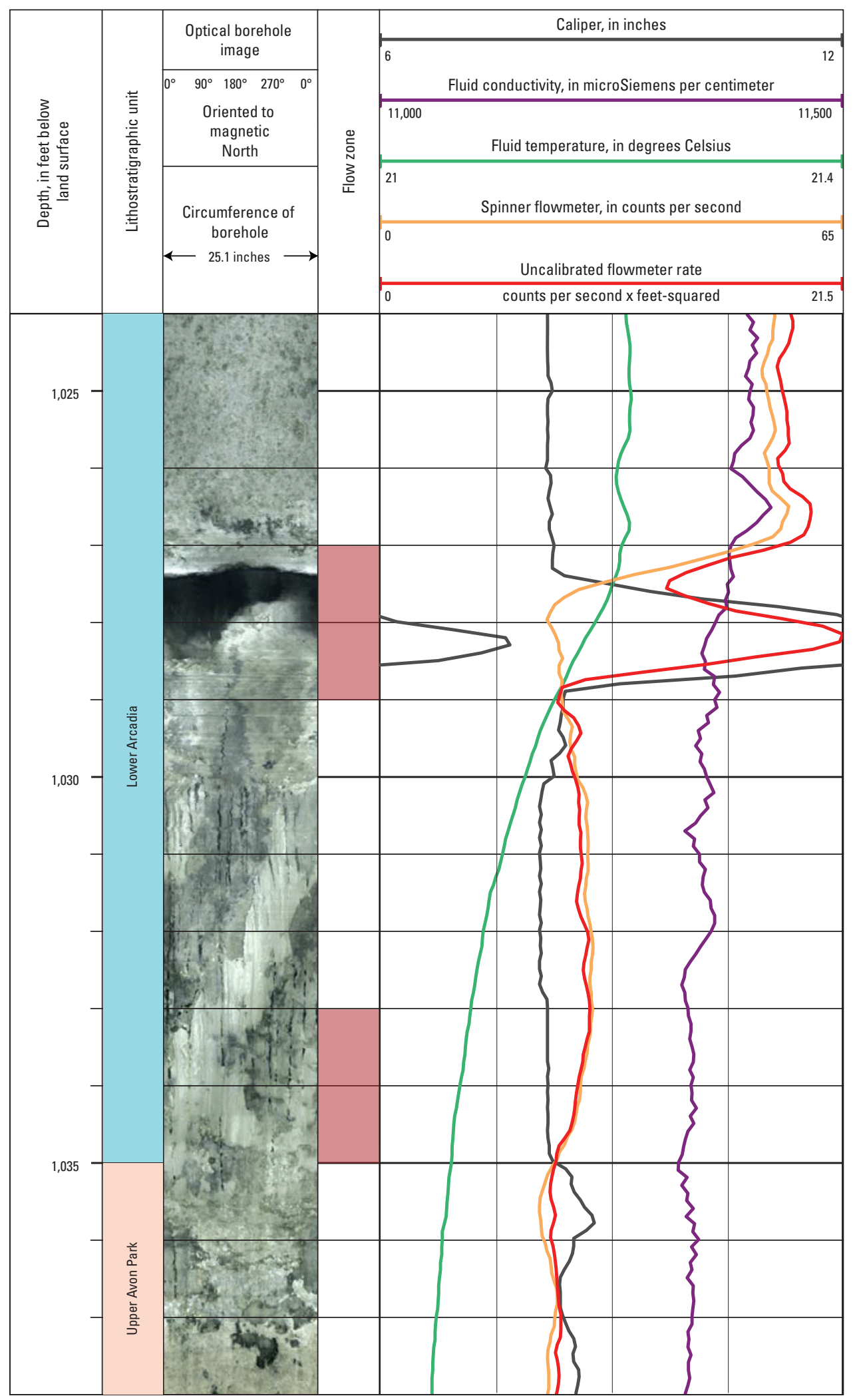

Figure 26. Borehole geophysical log data for well G-2940, from 1,024 to 1,038 feet below land surface (ft bls), including optical image, flowmeter and fluid properties, and flow zones. 
about 1,053 to $1,056 \mathrm{ft}$ bls (fig. 14) are all in the lowermost part of the Arcadia Formation, the paucity of data leave unclear whether these flow zones are related.

This preliminary analysis of this part of the Floridan aquifer system pore system is limited by the availability of reliable and sufficient geologic data and flowmeter measurements across flow zones at most of the well locations in the study area. Flowmeter data, naturally, are valuable indicators of the presence of individual flow zones, their vertical extent, and heterogeneity in flow properties, and flowmeter data are available for several wells in the study area. These data alone, however, do not indicate the lateral extent of the flow zones or their lateral heterogeneity. The G-2984 core data provide information on the geologic settings that correspond to the different types of flow zones in the Upper Floridan aquifer. Geologic settings are commonly spatially extensive, and the location of deposits characteristic of specific settings can thus sometimes be correlated between wells. In the study area, only a small number of core samples are available for a few wells to correlate with the data from G-2984, or to provide lithologic information for hydrologic units below the Upper Floridan aquifer, such as the Avon Park permeable zone and the uppermost permeable zone of the Lower Floridan aquifer. Optical and acoustic borehole image data can indicate the presence of some types of megaporosity, but flowmeter data are required to show whether megaporosity features are associated with increased hydraulic conductivity.

The dual nature of the porosity has implications for the evaluation of the suitability of the Floridan aquifer system for various water-resource management activities. Diffuse flow may be conducive for water storage, whereas concentrated flow may preclude containment. Thus, understanding the distribution of the types of flow is important in evaluation of the potential of a site for aquifer storage and recovery. For example, a relatively thick upper Floridan aquifer ASR production zone that contains subzones of diffuse-flow from matrix porosity and concentrated-flow from vuggy megaporosity could result in preferential movement of injected water into the megaporous zones and potential for movement beyond the estimated ASR capture volume. Furthermore, any type of predictive analyses (using analytical or numerical models), to access water-supply availability, would need to consider scaleappropriate heterogeneity of the types of flow, in both vertical and horizontal dimensions. The data presented here allow characterization of the scale of the vertical heterogeneity, but additional data would be needed to define the lateral extent, connectivity, and continuity of individual flow zones.

\section{Distribution of Salinity in the Upper Part of the Floridan Aquifer System}

The salinity distribution from the uppermost permeable zone of the Lower Floridan aquifer to the upper surface of the Floridan aquifer system in eastern Broward County can be characterized on the basis of analysis of direct measurements of water quality, for example dissolved-solids concentration, and indirect measurements of formation resistivity, which is used as a proxy for concentration of dissolved solids. Measured dissolved-solids concentration in groundwater samples are the most accurate measure of salinity, but data for the Floridan aquifer system in eastern Broward County may be difficult to compare between wells because sampling dates and borehole column intervals vary. Salinity may vary vertically over multiple contributing flow zones. Thus, a more discrete sample interval provides a more precise salinity measurement. Conversely, a large borehole column sampled interval is likely to be a composite salinity, which is more difficult to interpret. In any single well, sampled intervals within a specific hydrologic unit may produce water of varying salinity. For example, at site 17, well PB-1765, samples collected within a few days from two different intervals in the Upper Floridan aquifer show a greater than 2,000-mg/L difference in dissolved-solids concentration (appendix table 1-7; fig. 27). To assess temporal variability in salinity, multiple samples must be collected from depth-specific intervals. For example, at site 33, well G-2914, samples collected from the same depth interval $(1,110$ to $1,270 \mathrm{ft}$ bls) show a 1,500-mg/L difference in dissolved-solids concentration over 6 months (appendix table 1-7; fig. 27). Interpretations of the distribution of salinity in the Floridan aquifer system in eastern Broward County need to be considered in light of the variable sampling intervals and dates from the data set (appendix table 1-7).

A salinity classification scheme based on dissolved-solids concentration is used to describe the distribution of salinity in the Floridan aquifer system in this study. This scheme, modified from Fetter (1988), has three categories: (1) brackish water-dissolved-solids concentration ranges from 1,000 to $10,000 \mathrm{mg} / \mathrm{L}$, (2) moderately saline water-dissolved-solids concentration ranges from greater than 10,000 to $35,000 \mathrm{mg} / \mathrm{L}$, and (3) saline water-dissolved-solids concentration greater than $35,000 \mathrm{mg} / \mathrm{L}$.

In general, chemical analyses of water samples from the Upper Floridan aquifer indicate a trend in salinity from the highest values in the central part of the study area to lower values toward the north and south (fig. 27). Some samples from the west-central part of the study area, at sites 5 and 32, have concentrations of dissolved solids greater than $10,000 \mathrm{mg} / \mathrm{L}$. In the Avon Park permeable zone, salinity tends to be highest close to the coast, with several samples exceeding $10,000 \mathrm{mg} / \mathrm{L}$ dissolved-solids concentration, and lower toward the western part of the study area (fig. 28). Although salinity generally increases with depth, in some locations salinity measurements from samples in the Upper Floridan aquifer are higher than those in the Avon Park permeable zone, for example, at sites 5, 6, and 30 (figs. 27 and 28; appendix table 1-7).

Borehole formation resistivity data can be used to estimate the vertical distribution of salinity at the time the data are collected. Deep induction and other types of resistivity data were collected in 33 boreholes at 24 sites (appendix table 1-8). The dual-induction and shallow-resistivity tool, 


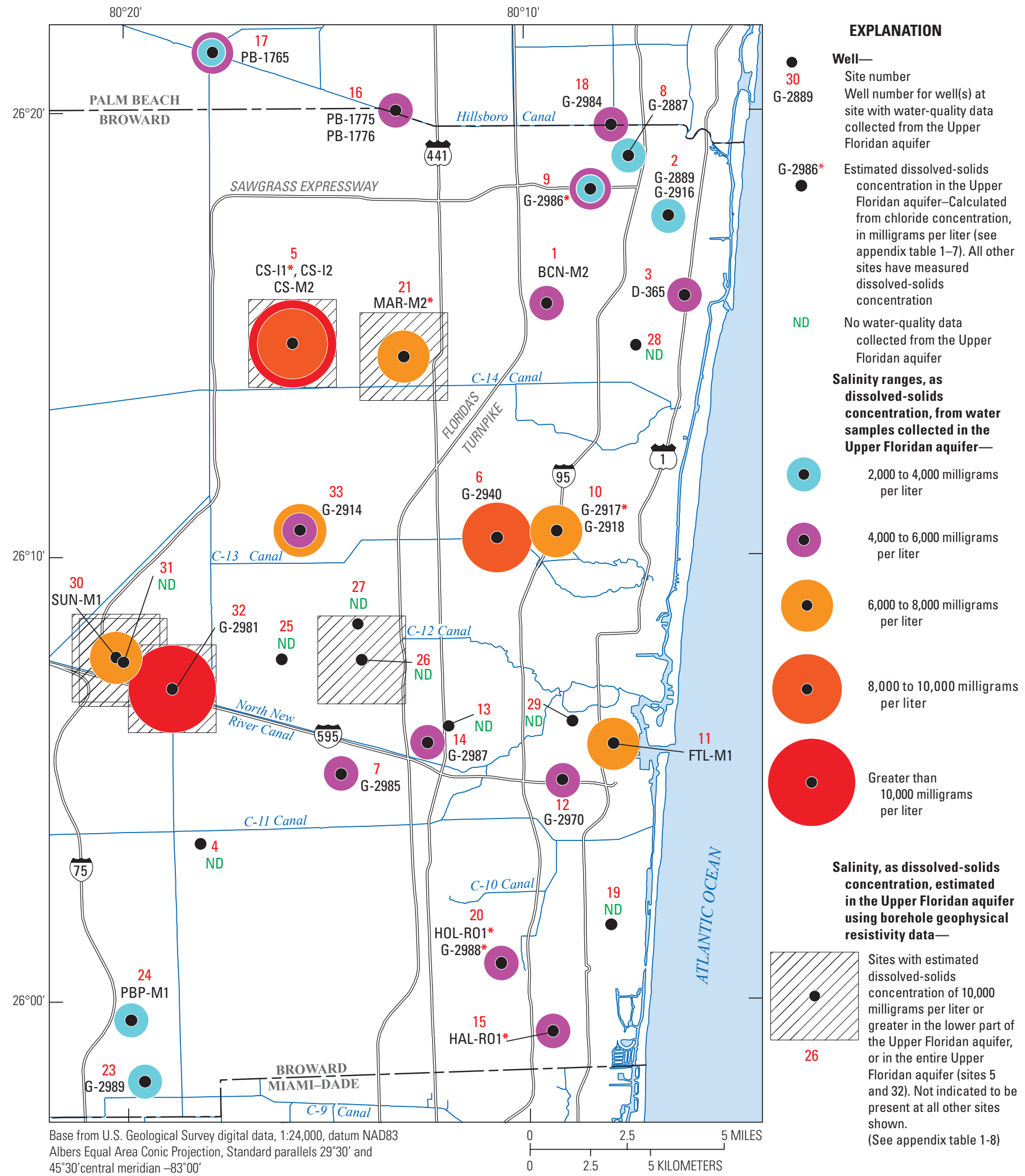

Figure 27. Distribution of salinity as dissolved-solids concentration in the Upper Floridan aquifer. 


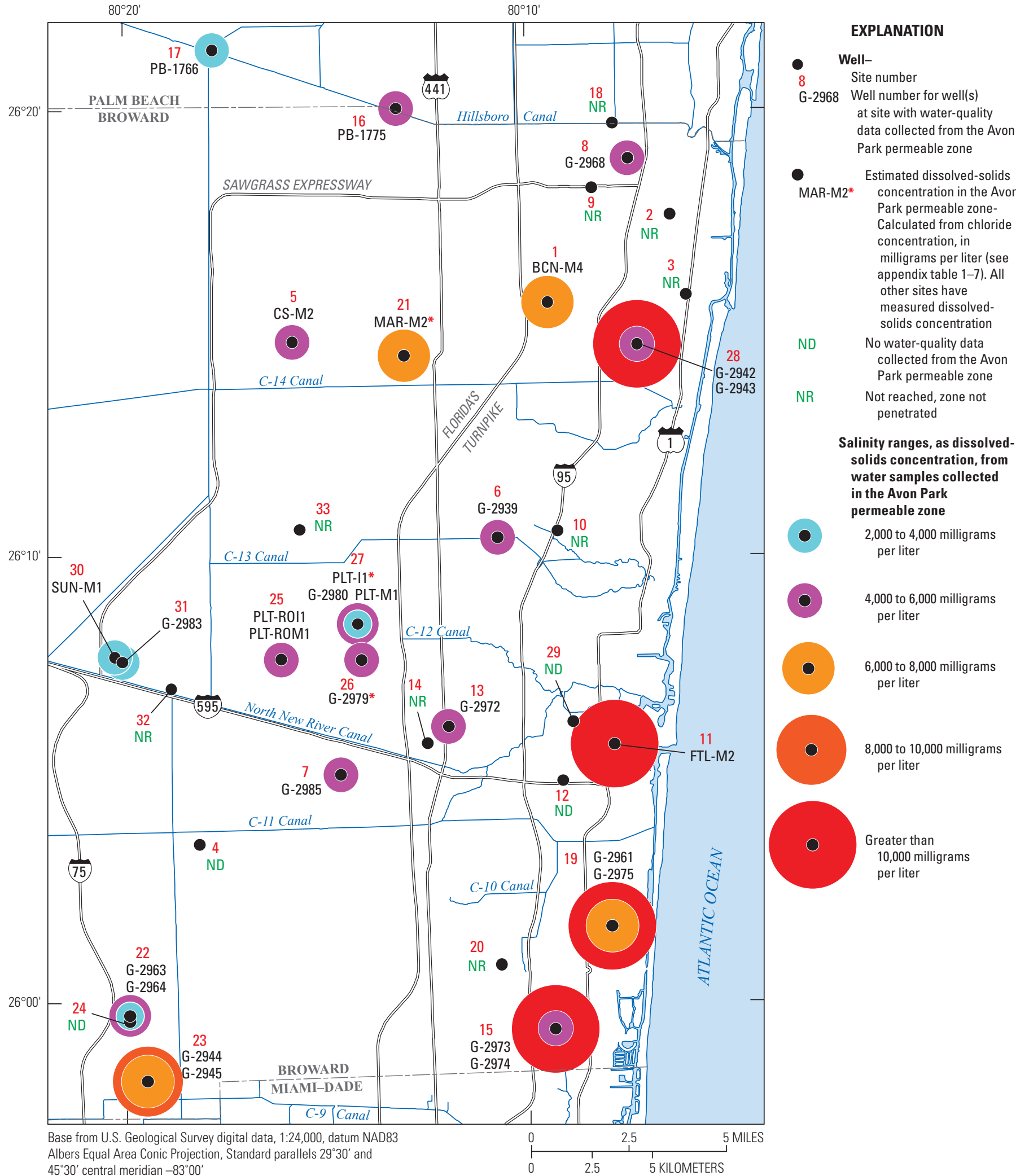

Figure 28. Distribution of salinity as dissolved-solids concentration in the Avon Park permeable zone. 
which includes the deep induction array, measures resistivity at three radial distances from the borehole into the formation: shallow, medium and deep (fig. 29), and data from this tool were available from 31 of the 33 boreholes. The deep-induction measurements were found to approximate true formation resistivity where there was an absence of saline drilling fluid (Reese, 1994), and these types of resistivity data were available for 32 of the 33 boreholes. The shallow and intermediate resistivity data can be used to determine whether excessive invasion into the formation by drilling fluids has occurred. Using the empirical Archie's law (1942), and values for formation resistivity, porosity, cementation factor, and formation temperature for the upper part of the Floridan aquifer system in southeast Florida (Reese, 1994), groundwater salinity of $10,000 \mathrm{mg} / \mathrm{L}$ dissolved solids was estimated to be represented by a formation resistivity of 4-6 ohm-meters. This value of formation resistivity is based on a porosity estimate of 30 to 40 percent, a cementation factor of 1.8 to 2.1 , and a formation temperature of 20 to 26 degrees Celsius.

Estimates of salinity from borehole resistivity data, supported by results of chemical analyses, were used to map the deepest occurrence of groundwater with concentrations of dissolved solids less than $10,000 \mathrm{mg} / \mathrm{L}$ (fig. 30: appendix table 1-8). The $10,000 \mathrm{mg} / \mathrm{L}$ dissolved solids threshold marks the greatest salinity allowable in an underground source of drinking water (USDW) (Florida Administrative Code, 2008). At depths greater than the USDW surface (fig. 30), no additional sources of drinking water are likely to be available. This surface generally becomes progressively deeper from the coast toward the west (fig. 30). Resistivity and waterquality data from several sites, however, indicate that above this surface, an interval of groundwater with salinity greater than $10,000 \mathrm{mg} / \mathrm{L}$ dissolved solids may occur in the Upper Floridan aquifer, for example at sites 5, 21, 26, 30, 31, and 32 (figs. 27, 28 and 30; appendix table 1-8). These sites are in the west-central part of the study area, where the Upper Floridan aquifer generally deepens. A conceptual model developed from these data show the presence of a zone of moderately saline water perched above brackish water in the west-central part of the study area (fig. 31). The sites with highest directlymeasured salinity in the Upper Floridan aquifer also occur at the sites with the lowest estimated transmissivity (fig. 32). The occurrence of a zone of moderately-saline water in the Upper Floridan aquifer perched above less saline water in the Avon Park permeable zone may be the result of incompletely flushed connate water or intruded seawater, in structurally lower, less permeable parts of the Upper Floridan aquifer.

\section{Summary and Conclusions}

Concerns about water-level declines and saltwater intrusion in the Biscayne aquifer have prompted water managers in Broward County to examine the potential use of the Floridan aquifer system as an alternative water supply, either directly, by pumping from supply wells and treating the water, or indirectly, by aquifer storage and recovery (ASR). The ability to predict physical properties of the Floridan aquifer system conducive to its use as an alternative water supply or for ASR requires a refined hydrogeologic framework, and information about the distribution of salinity of the water. This report provides information that can be used to assist decisions about the management of the Floridan aquifer system by (1) identifying major permeable zones and semiconfining units of the Floridan aquifer system - from the upper flow zone of the Lower Floridan aquifer to the top of the Upper Floridan aquifer - and delineating their configuration, thickness, and extent; (2) providing estimated values and other information on hydraulic properties of these units; and (3) describing the distribution of salinity within these units.

The information used to refine the hydrogeologic framework includes lithologic data, borehole geophysical data, and reflection-seismic data. A test corehole, G-2984 was drilled from land surface into the uppermost permeable zone of the Lower Floridan aquifer, and was continuously cored from the top of the Upper Floridan aquifer to the bottom of the well. The core was analyzed for lithologic properties, depositional features, bedding thickness, and fossils. Optical and acoustic images of the borehole (OBIs and ABIs) were collected. Other borehole geophysical data collected include: natural gamma-ray activity (GR), caliper, induction formation resistivity (rock plus groundwater), spontaneous potential, single point resistance, sonic $\Delta t$, flowmeter, and borehole fluid conductivity and temperature. Borehole geophysical and lithologic data from other wells in the study area were compiled. Reflection-seismic data were collected along the Hillsboro Canal. These data were used to identify lithostratigraphic units and stratigraphic sequences, and to construct the hydrogeologic framework. Salinity distribution in the Floridan aquifer system was characterized using existing water-quality data, including specific conductance, formation resistivity, and chloride, sulfate, and dissolved-solids concentration.

Stratigraphic units identified in the study area include, in ascending order, the lower Avon Park Formation, the lowermiddle Avon Park Formation, the upper-middle Avon Park Formation, the upper Avon Park Formation, the lower Arcadia Formation, and the upper Arcadia Formation. The upper contact of the Avon Park Formation deepens from east to west across the study area. An isolated structural low is observed near G-2984, and is associated with faults and a paleocollapse feature identified on the Hillsboro seismic reflection profile. The upper Avon Park Formation is generally thinnest in the central and southeastern part of the study area, and thickens toward the north and southwest. The lower Arcadia Formation generally thickens from south to north across the study area.

Six depositional sequences were identified in the G-2984 test corehole, from deepest to shallowest: Avon Park sequence 1, Avon Park sequence 2, and Arcadia sequences 1 through 4 . The depositional sequences were identified and correlated with lithologic and borehole geophysical data, and used to map sequence surfaces and their thicknesses. 


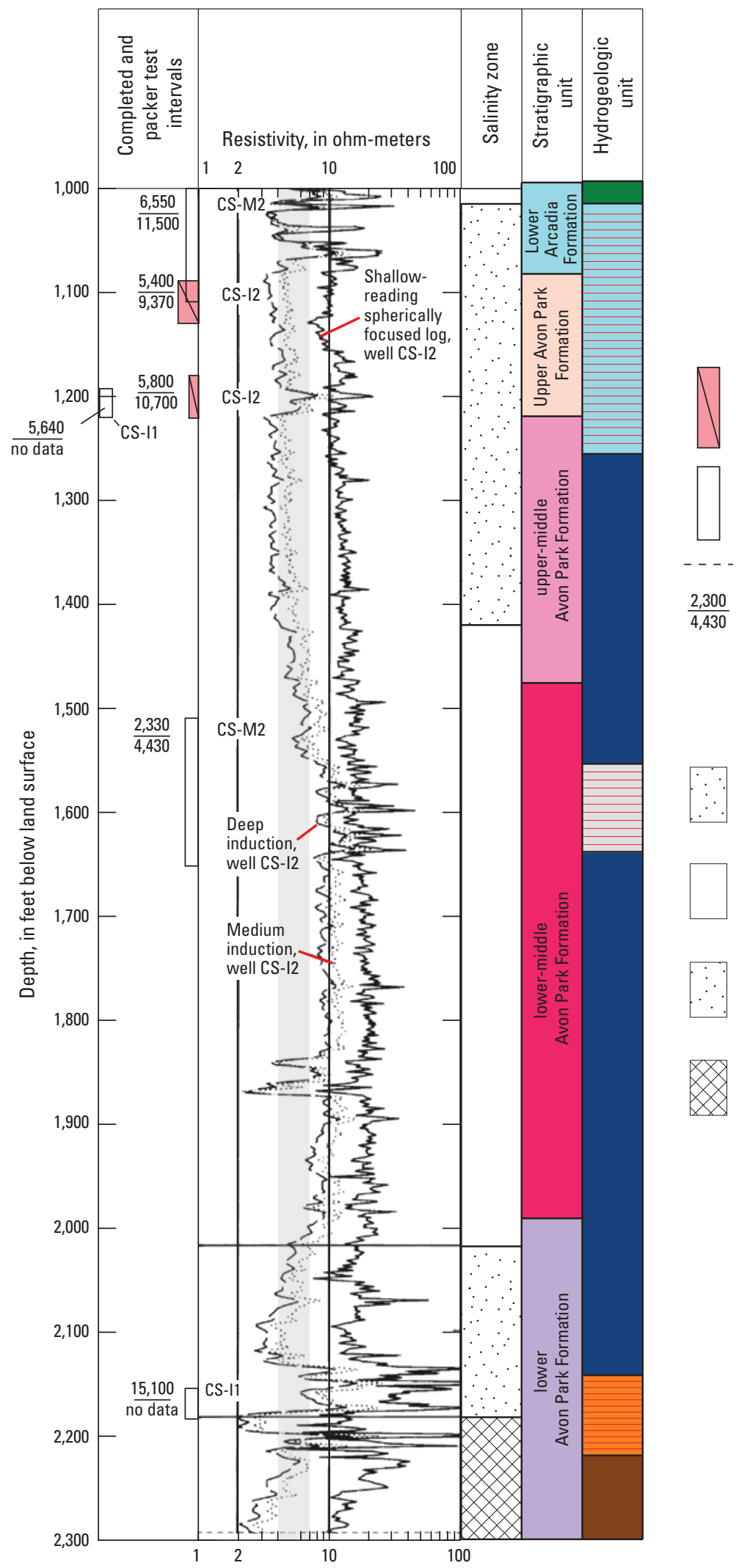

\section{EXPLANATION}

Packer test interval in well CS-12

Completed interval in well

CS-M2 or CS-I1

Bottom of logged interval

Salinity-Water samples collected from completed intervals and packer test intervals. Upper number is chloride concentration, and lower number is dissolved-solids concentration. Concentrations shown in milligrams per liter

Salinity ranges and definitions of zone boundaries in salinity zone column-

Moderately saline water, upper zone-Dissolved-solids concentration range from 10,000 to 35,000 milligrams per liter. Depth of base of zone estimated by deep induction resistivity less than $4 \mathrm{ohm}$-meters

Brackish water-Dissolved-solids concentration range from 1,000 to 10,000 milligrams per liter. Depth of base of zone estimated by deep induction resistivity less than 6 ohm-meters

Moderately saline water, lower zone-Dissolved-solids concentration range from 10,000 to 35,000 milligrams per liter. Depth of base of zone estimated by deep induction resistivity less than 2 ohm-meters

Saline water-Dissolved-solids concentration of about 35,000 milligrams per liter or slightly higher

Figure 29. Water-quality data, resistivity geophysical log data, salinity zones, and lithostratigraphic and hydrogeologic units for wells at site 5 . The data shown are from wells CS-I1, CS-I2, and CS-M2 at the site. CS-I1 is 750 feet south of CS-I2. Modified from Reese (1994). Well CS-I2 is also shown in figure 6. 


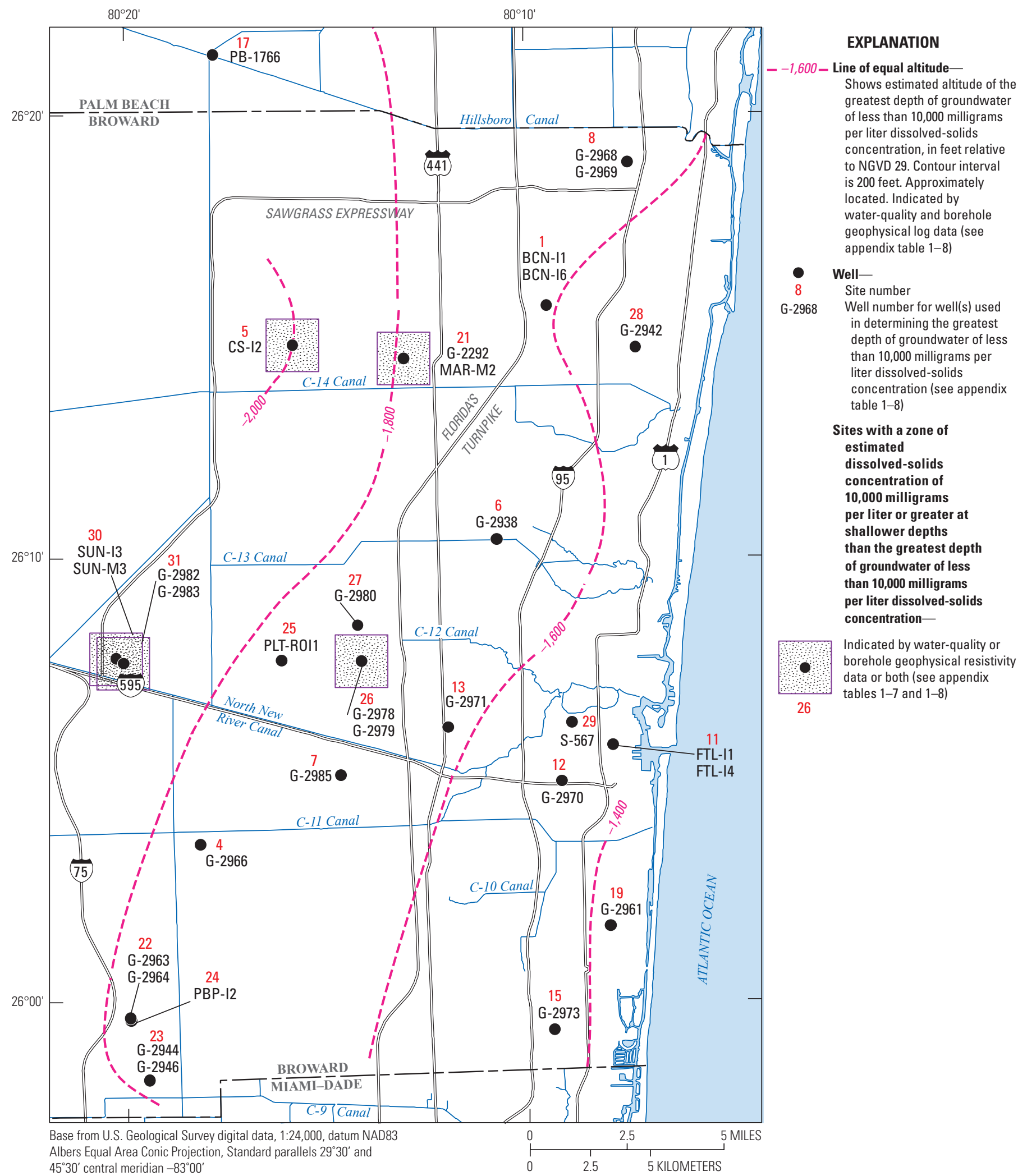

Figure 30. Greatest depth of groundwater with dissolved solids concentration of less than or equal to 10,000 milligrams per liter. 


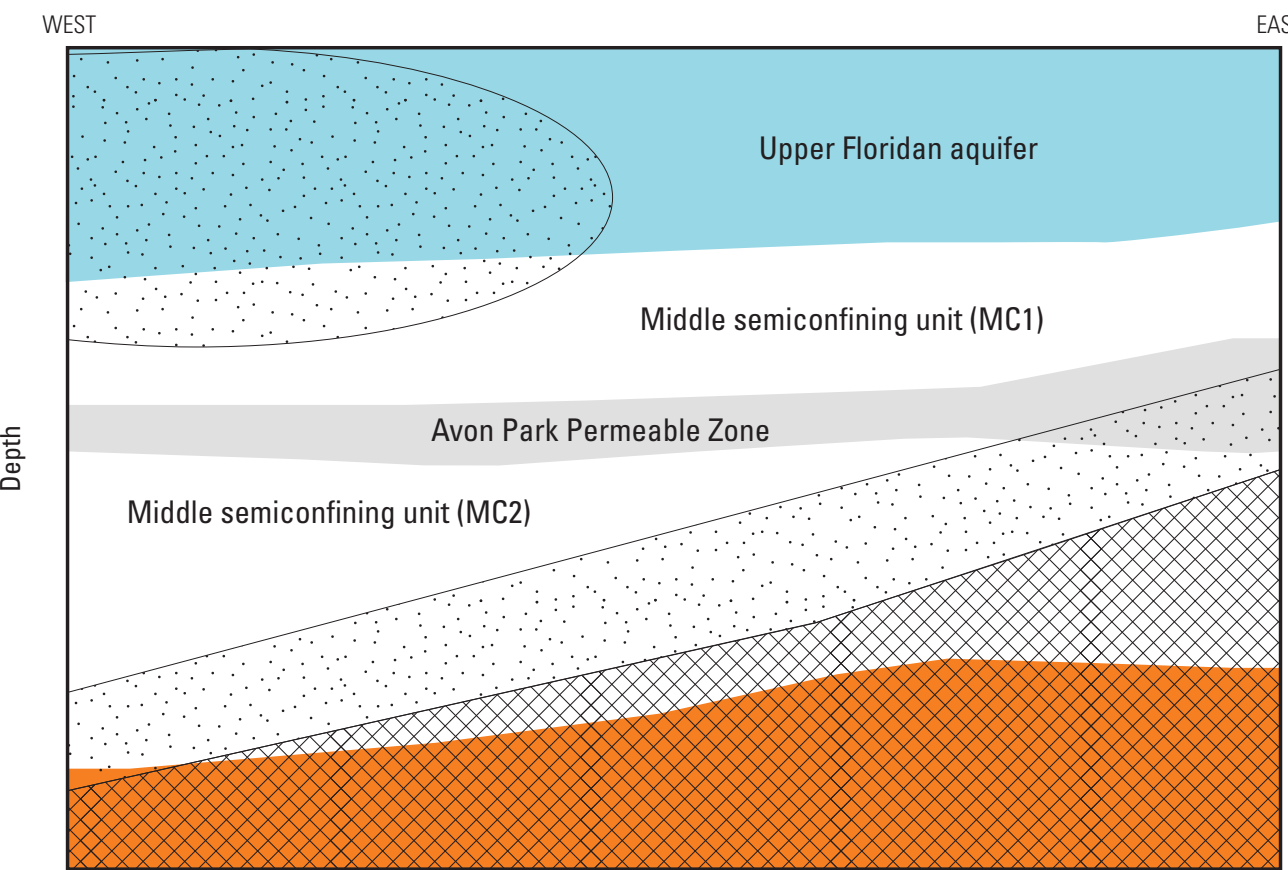

NOT TO SCALE
EAST
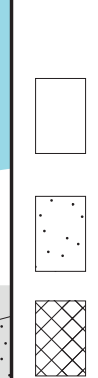

\section{EXPLANATION}

\section{Salinity range}

Dissolved-solids concentration (no pattern) range from 1,000 to less than 10,000 milligrams per liter

Dissolved-solids concentration range from 10,000 to 35,000 milligrams per liter

Dissolved-solids concentration greater than 35,000 milligrams per liter or higher

Figure 31. Schematic diagram showing perched zone of elevated salinity in the Upper Floridan aquifer in the west central part of the study area.

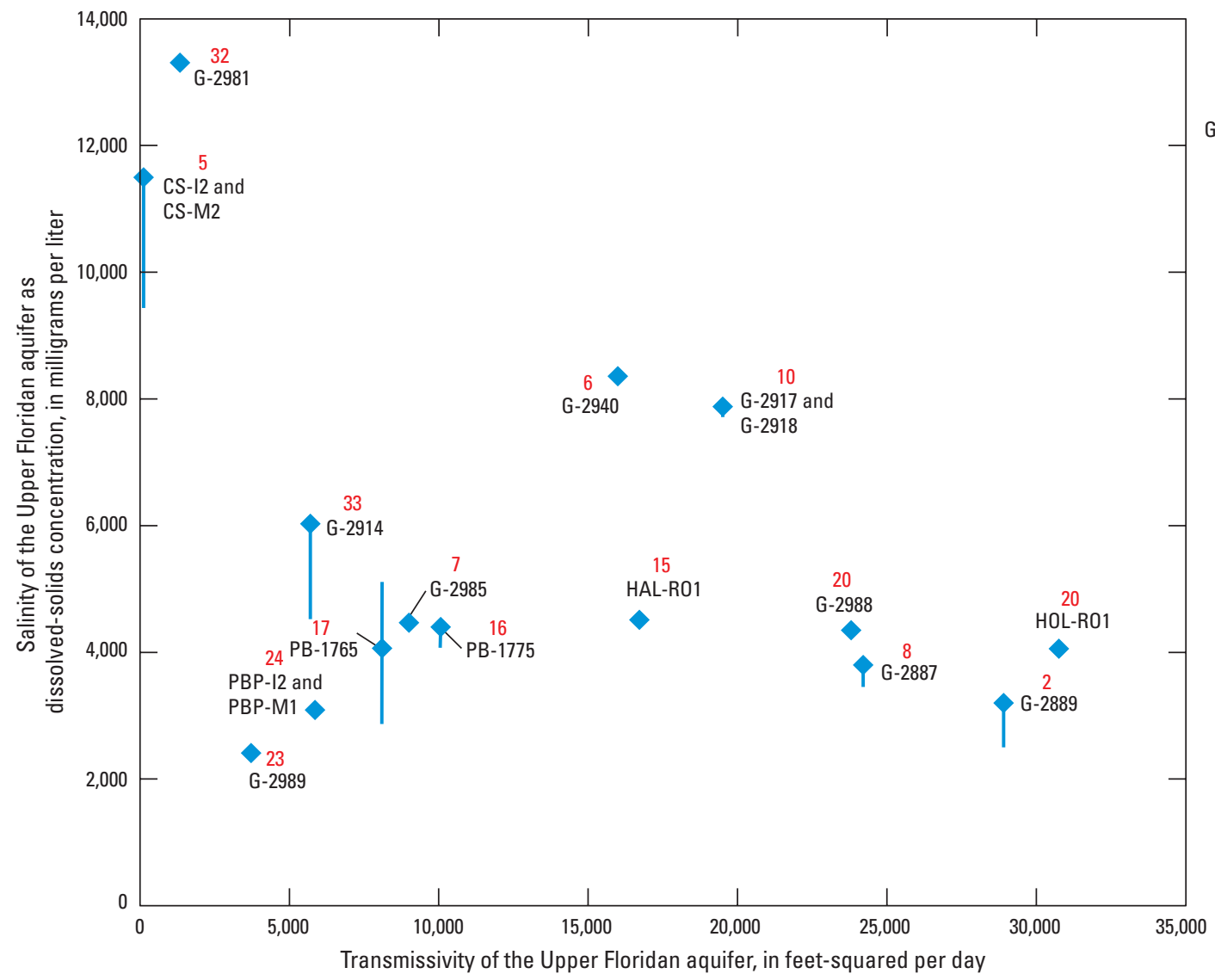

\section{Data point-}

33 Site number

G-2914 Well number(s). If more than on well number is shown, first well is source of transmissivity value at the site and second well is source of salinity value

Data point and range in salinityShows range in salinity at sites with more than one sample from the Upper Floridan aquifer. In some cases samples were collected from multiple wells at a single site

Figure 32. Relation between transmissivity and salinity in the Upper Floridan aquifer. 
The seismic-reflection data acquired along the Hillsboro Canal were correlated with geologic, hydrogeologic, and geophysical data from proximal wells, and show a continuous, thick, 2-dimensional profile of the major lithostratigraphic, sequence stratigraphic and hydrogeologic units across the study area. The Arcadia Formation and upper and middle Avon Park Formation generally show parallel to subparallel, flat to wavy or hummocky reflection configuration patterns. Seven narrow segments were identified that contain seismicsag structural systems. These seismic-sag systems extend upward from the Avon Park Formation to the upper contact of the Arcadia Formation and are interpreted as downward deformation of overlying strata into collapsed deep cave systems. Faulting and fracturing associated with these systems could provide passageways for vertical fluid flow and cause upconing of saline water at water-supply or ASR wells in the Floridan aquifer system.

The hydrogeologic framework of the Floridan aquifer system in eastern Broward County, from the top of the Floridan aquifer system to the bottom of the uppermost permeable zone of the Lower Floridan aquifer, was constructed using borehole geophysical data, flowmeter analyses, and borehole images and lithologic data. The Upper Floridan aquifer in the study area generally correlates with part of the lower Arcadia Formation, the upper Avon Park Formation, and the upper part of the upper-middle Avon Park Formation. Throughout the study area, the upper surface of the Upper Floridan aquifer occurs within the lower Arcadia Formation, below the upper surface of the lower Arcadia Formation. The bottom of the Upper Floridan aquifer generally occurs within the upper-middle Avon Park Formation, although it may correlate with the upper surface of the upper-middle Avon Park Formation or occurs within the upper Avon Park Formation in the southwestern part of the study area. Transmissivity of the Upper Floridan aquifer generally increases from west to east across the study area. The occurrence and thicknesses of flow zones below the top of the Avon Park sequence 1 within the Upper Floridan aquifer decrease to the west. Although the Avon Park sequence 2 thickens to the west, only one thin flow zone occurs in some locations, associated with the upper contact of the Avon Park Formation.

Beneath the middle semiconfining unit 1, the Avon Park permeable zone is identified by an increase in the number and spatial density of flow zones relative to overlying and underlying semi-confining units. The Avon Park permeable zone generally occurs within the upper part of the lower-middle Avon Park Formation. Transmissivity values of the Avon Park permeable zone are generally lower than for the Floridan aquifer system, but vary over a similar range of orders of magnitude. The overlying middle semiconfining zone 1 and underlying middle semiconfining zone 2 are each hundreds of feet thick, and estimated hydraulic conductivity values of the semi-confining units are one to several orders of magnitude lower than for the Avon Park permeable zone. The Lower Floridan 1 is identified by the presence of an increased number and spatial density of flow zones relative to the overlying middle semiconfining unit 2 , and the hydraulic properties are comparable to the Upper Floridan aquifer and Avon Park permeable zone.

Core samples, optical and acoustic borehole images, flowmeter data, and other borehole geophysical data from the G-2984 test corehole were examined to characterize the relationship between rock depositional textures, associated pore networks, and flow zones. A thin flow zone, contributing substantial and concentrated flow into the borehole, is formed by two open bedding-plane vugs at the upper surface of the Floridan aquifer system. A thicker zone of diffuse flow deeper in the aquifer system was identified, with interparticle porosity as the dominant pore type. Still deeper in the Upper Floridan aquifer, a zone containing both diffuse flow and concentrated flow was identified. The diffuse flow is associated with mostly interparticle and moldic-particle pore types, whereas concentrated groundwater flow is associated with vuggy megaporosity.

Using flowmeter data and optical images, flow zones in two additional boreholes (G-2940 and PB-1775) were also characterized. In both boreholes, concentrated flow zones in the lower Arcadia Formation are associated with thin beddingplane vugs. It is unclear if these flow zones are related.

These data support a conceptual model of groundwater flow in the Floridan aquifer system in Broward County wherein concentrated flow occurs in discrete, thin, bedding plane vugs or zones of vuggy megaporosity, and diffuse flow tends to occur through interparticle or moldic-particle porosity in matrix-dominated lithologies. Considerable groundwater exchange may occur between such zones of different type porosity. The dual nature of the porosity is an important consideration in the suitability of the Floridan aquifer system for various water-resource management activities: zones of diffuse flow may be more conducive for storage of water, whereas zones of concentrated flow may prohibit containment. For example, a relatively thick ASR production zone in the Upper Floridan aquifer that contains subzones of diffuse-flow from matrix porosity and concentrated-flow from vuggy megaporosity could result in preferential movement of injected water through the megaporous zones and migration outside of the ASR capture volume. Furthermore, any type of predictive analyses would need to consider scale-appropriate heterogeneity of the types of flow, in both vertical and horizontal dimensions.

Existing water-quality data were used to characterize the distribution of salinity in the Floridan aquifer system in eastern Broward County. In general, higher salinity values are observed in the central part of the study area, and lower salinity values are observed toward the north and south. Although salinity generally increases with depth, in the west-central part of the study area a zone of relatively more saline water in the Upper Floridan aquifer is perched above less saline water in the underlying Avon Park permeable zone. The areas with the highest salinity are also those with the lowest estimated transmissivity, indicating that the occurrence of perched saline water in the Upper Floridan aquifer may be a consequence of incompletely flushed connate water or intruded seawater. 


\section{References Cited}

Applin, P.L., and Applin, E.R., 1944, Regional subsurface stratigraphy and structure of Florida and southern Georgia: Bulletin of the American Association of Petroleum Geologists, v. 28, no. 12, p. 1673-1742.

Archie, G.E., 1942, The electrical resistivity log as an aid in determining some reservoir characteristics: Journal of Petroleum Technology, v. 5, no. 1.

Arthur, J.D., Fischler, Cindy, Kromhout, Clint, and others, 2008, Hydrogeologic framework of the Southwest Florida Water Management District: Florida Geological Survey Bulletin no. 68,98 p., 2 apps., 59 pls.

Bennett, M.W., Linton, P.F., and Rectenwald, E.E., 2001, Completion report for the exploratory well EXW-1, western Hillsboro basin site, Palm Beach County: South Florida Water Management District hydrogeologic investigation of the Floridan aquifer system, 34 p., 7 apps.

Budd, D.A, and Vacher, H.L., 2004, Matrix permeability of the confined Floridan aquifer, Florida, USA: Hydrogeology Journal, v. 12, p. 531-549.

Bush, P.W., and Johnston, R.H., 1988, Ground-water hydraulics, regional flow, and ground-water development of the Floridan aquifer system in Florida and in parts of Georgia, South Carolina, and Alabama: U.S. Geological Survey Professional Paper 1403-C, 80 p.

Camp, Dresser, and McKee, Inc., 1991a, City of Plantation Central District Water Treatment Facility R.O. reject disposal well - no. 1: Well completion report v. 1 .

Camp, Dresser, and McKee, Inc., 1996, Engineering report supporting operational testing of IW-3 at Sunrise, Florida: Engineering report prepared for City of Sunrise, Fla., v. 1, p. 1-1 to 8-3, plus apps.

Camp, Dresser, and McKee, Inc., 2008, City of Deerfield Beach West Water Treatment Plant concentrate injection well system: Well completion report, v. 1, p. 1-1 to 7-1, plus apps.

Catuneanu, O., Abreu, V., Bhattacharya, J.P., and others, 2009, Towards the standardization of sequence stratigraphy: Elsevier B.V., Earth-Science Reviews v. 92, p. 1-33.

CH2M HILL, 1999, Construction and testing of injection well IW-4 at the City of Fort Lauderdale G.T. Lohmeyer Wastewater Treatment Plant: Engineering report prepared for the City of Fort Lauderdale, v. I, p. 1-1 to 6-1, plus apps.

Cunningham, K.J., McNeill, D.F., Guertin, L.A., and others, 1998, New Tertiary stratigraphy for the Florida Keys and southern peninsula of Florida: Geological Society of America Bulletin, v. 110, no. 2, p. 231-258.
Cunningham, K.J., Bukry, David, Sato, Tokiyuki., and others, 2001a, Sequence stratigraphy of a south Florida carbonate ramp and bounding siliciclastics (Late Miocene-Pliocene), in Missimer, T.M. and Scott, T.M., eds., Geology and hydrology of Lee County, Florida: Durward H. Boggess Memorial Symposium: Florida Geological Survey Special Publication no. 49, p. 35-66.

Cunningham, K.J., Locker, S.D., Hine, A.C., and others, 2001b, Surface-geophysical characterization of groundwater systems of the Caloosahatchee River basin, southern Florida: U.S. Geological Survey Water-Resources Investigations Report 01-4084, 76 p.

Cunningham, K.J., Locker, S.D., Hine, A.C., Bukry, D., Barron, J.A., and Guertin, L.A., 2003, Interplay of late Cenozoic siliciclastic supply and carbonate response on the southeast Florida Platform: Journal of Sedimentary Research, v. 73, p. 31-46.

Cunningham, K.J., and Walker, C., 2009, Seismic-sag structures in Tertiary carbonate rocks beneath southeastern Florida, USA: Evidence for hypogenic speleogenesis? in Klimchouk, A.B., and Ford, D.C., eds., Hypogene Speleogenesis and Karst Hydrogeology of Artesian Basins: Simferopol, Ukraine, Ukrainian Institute of Speleology and Karstology, Special Paper no. 1, p. 151-158, accessed March 20, 2014 at http://institute.speleoukraine.net/libpdf/Cunningham\%20 Walker_SEISMIC-SAG\%20STRUCTURAL\%20 SYSTEMS\%20IN\%20FLORIDA_HypoConf_2009.pdf.

Duncan, J.G., Evans III, W.L., and Taylor, K.L., 1994a, Geologic framework of the Lower Floridan aquifer system, Brevard County, Florida: Florida Geological Survey Bulletin 64, $90 \mathrm{p}$.

Duncan, J.G., Evans III, W.L., Aylor, J.G., and Li Li, 1994b, Geologic framework of the Lower Floridan aquifer system, St. Lucie, Martin, and Palm Beach Counties, Florida: Florida Geological Survey contractual report submitted to the Florida Department of Environmental Protection Bureau of Drinking and Ground Water Resources UIC, Criteria and standards DEP contract \#WM514, November 1994, 64 p.

Fetter, C.W., 1988, Applied hydrogeology (2d ed.): Columbia S.C., Merrill Publishing, 592 p.

Fish, J.E., 1988, Hydrogeology, aquifer characteristics, and ground-water flow of the surficial aquifer system, Broward County, Florida: U.S. Geological Survey Water-Resources Investigations Report 87-4034, 92 p.

Florida Administrative Code, 2008, Florida Department of Environmental Protection, Underground Injection Control, chap. 62-528.

Florida Geological Survey, 2012, Lithologic database: Accessed December 11, 2012, at http://publicfiles.dep.state. fl.us/FGS/WEB/lithologic/. 
Geological Society of America, 1995, Rock Color Chart: Baltimore, Maryland, Munsell Color.

Geraghty and Miller, Inc., 1990, Construction and testing of injection wells \#1 and \#2 with associated deep monitor well \#1, Broward County North District Regional Wastewater Treatment Plant: Report prepared for James M. Montgomery, Consulting Engineers, Inc. in association with Hazen and Sawyer, P.C, Engineers, 30 p., plus apps.

Guertin, L.A., Missimer, T.M., and McNeill, D.F., 2000, Hiatal duration of correlative sequence boundaries from Oligocene-Pliocene mixed carbonate/siliciclastic sediments of the south Florida Platform: Sedimentary Geology, v. 134, p. 1-26.

Hammes, Ursula, 1992, Sedimentation patterns, sequence stratigraphy, cyclicity, and diagenesis of early Oligocene carbonate ramp deposits, Suwannee Formation, southwest Florida, U.S.A: University of Colorado, dissertation, 344 p.

Hazen and Sawyer, P.C., 2003, Engineering well completion report, Hollywood Southern Regional WWTP injection well effluent disposal system: Prepared for the City of Hollywood in association with Water Technologies Associates, Inc., p. 1-1 to 5-5, plus apps.

Hazen and Sawyer, P.C., 2006, Engineering well completion report, - Peele-Dixie Water Treatment Plant concentrate disposal well: Prepared for City of Fort Lauderdale, p. 1-1 to 5-5, plus apps.

Hazen and Sawyer, P.C., 2007, Engineering well completion report Hallandale Beach WTP concentrate disposal well: Prepared for the City of Hallandale Beach, p. 1-1 to 5-5, plus apps.

Henderson, Don, 2009, Sonic logs_-Some causes for bad logs, editing options: Henderson Petrophysics Consulting Formation Evaluation Services for the Oil and Gas Industry: Accessed January 10, 2012, at http://www. hendersonpetrophysics.com/sonic.

Hine, A.C., 2013, Geologic history of Florida: major events that formed the sunshine state: Gainesville, Florida, University of Florida Press, 230 p.

James, N.P., 1997, The cool-water carbonate depositional realm, in: Cool-Water Carbonates Edited by Noel P. James and Jonathan A. D. Clarke. Vol. 56. 1997. P.1-20

Kerans, C., and Tinker, S.W., 1997, Sequence stratigraphy and characterization of carbonate reservoirs: SEPM Short Course Notes, no. 40, 130 p.

Kohout, F.A., 1960, Cyclic flow of salt water in the Biscayne aquifer of southeastern Florida: Journal of Geophysical Research, v. 65, no. 7, p. 2133-2141.
Lukasiewicz, John, 2003, Floridan aquifer system test well program, C-13 Canal, Oakland Park, Florida: South Florida Water Management District Technical Publication WS-16, 49 p., plus apps.

Maliva, R.G., Missimer, T.M., Clayton, E.A., and others, 2009, Diagenesis and porosity preservation in Eocene microporous limestones, South Florida, USA: Sedimentary Geology, v. 217, p. 85-94.

Martin, J.B., and Screaton, E.J., 2001, Exchange of matrix and conduit water with examples from the Floridan aquifer, in E.L. Kuniansky, ed., U.S. Geological Survey Karst Interest Group Proceedings, St. Petersburg, Florida, February 13-16, 2001: U.S. Geological Survey Water-Resources Investigations Report 01-4011, p. 38-44.

McDonnell, A., Loucks, R.G., and Dooley, T., 2007, Quantifying the origin and geometry of circular sag structures in northern Fort Worth Basin, Texas-Paleocave collapse, pull-apart fault systems, or hydrothermal alteration?: American Association of Petroleum Geologists Bulletin, v. 91, p. 1295-1318.

Meyer, F.W., 1988, Summary of well construction, testing, and preliminary findings from the Alligator Alley test well, Broward County, Florida: U.S. Geological Survey OpenFile Report 87-551, 68 p.

Meyer, F.W., 1989, Hydrogeology, ground-water movement, and subsurface storage in the Floridan aquifer system in southern Florida: U.S. Geological Survey Professional Paper 1403-G, 59 p.

Miller, J.A., 1986, Hydrogeologic framework of the Floridan aquifer system in Florida and in parts of Georgia, Alabama, and South Carolina: U.S. Geological Survey Professional Paper 1403-B, 91 p.

Missimer, T.M., 2002, Late Oligocene to Pliocene evolution of the central portion of the south Florida platform-Mixing of siliciclastic and carbonate sediments: Florida Geological Survey Bulletin no. 65, 184 p., plus pls.

Mitchum, R.M., Jr., Vail, P.R., and Sangree, J.B., 1977, Seismic stratigraphy and global changes of sea level, part 6: Stratigraphic interpretation of seismic reflection patterns in depositional sequences, in Payton, C.E., ed., Seismic stratigraphy-Applications to hydrocarbon exploration: American Association of Petroleum Geologists, Memoir 26, p. 117-133.

Montgomery Watson, 1996, City of Miramar Western Water Treatment Plant Injection Well System, Injection Wells IW-1 and IW-2 and Monitor Well DZMW-1: Prepared for the City of Miramar, Florida, 2 reports plus apps. 
Neuendorf, K.K.E., Mehl, J.P., Jr., and Jackson, J.A., 2005, Glossary of geology: American Geological Institute, Alexandria, Va., $779 \mathrm{p}$.

Powell, J.B., 2010, Larger foraminiferal biostratigraphy, systematics and paleoenvironments of the Avon Park Formation and Ocala Limestone, Highlands County, Florida: Florida International University, Ph.D. dissertation, 239 p.

Reese, R.S., 1994, Hydrogeology and the distribution and origin of salinity in the Floridan aquifer system, southeastern Florida: U.S. Geological Survey Water-Resources Investigations Report 94-4010, 56 p.

Reese, R.S., 2000, Hydrogeology and the distribution of salinity in the Floridan aquifer system, southwestern Florida: U.S. Geological Survey Water-Resources Investigations Report 98-4253, 86 p., 10 pls.

Reese, R.S., 2002, Inventory and review of aquifer storage and recovery in southern Florida: U.S. Geological Survey Water-Resources Investigations Report 02-4036, 55 p.

Reese, R.S., 2004, Hydrogeology, water quality, and distribution and sources of salinity in the Floridan aquifer system, Martin and St. Lucie Counties Florida: U.S. Geological Survey Water-Resources Investigations Report 03-4242, 96 p., 2 pls.

Reese, R.S., and Alvarez-Zarikian, C.A., 2007, Hydrogeology and aquifer storage and recovery performance in the Upper Floridan aquifer, southern Florida, U.S. Geological Survey Scientific Investigations Report 2006-5239, 110 p., plus apps. (on CD).

Reese, R.S. and Cunningham, K.J., 2000, Hydrogeology of the gray limestone aquifer in southern Florida: U.S. Geological Survey Water-Resources Investigations Report 99-4213, 77 p., plus apps.

Reese, R.S., and Memberg, S.J., 2000, Hydrogeology and the distribution of salinity in the Floridan aquifer system, Palm Beach County, Florida: U.S. Geological Survey WaterResources Investigations Report 99-4061, 52 p., 2 pls.

Reese, R.S. and Richardson, Emily, 2008, Synthesis of the hydrogeologic framework of the Floridan aquifer system and delineation of a major Avon Park permeable zone in central and southern Florida: Scientific Investigations Report 2007-5207, 60 p., plus apps. and pls. (on CD).

Schlager, Wolfgang, 2005, Carbonate sedimentology and sequence stratigraphy: Tulsa, Okla., Society of Economic Paleontologist and Mineralogist Concepts in Sedimentology and Paleontology no. 8, 199 p.
Scott, T.M., 1988, The lithostratigraphy of the Hawthorn group (Miocene) of Florida: Florida Geological Survey Bulletin 59, $147 \mathrm{p}$.

Screaton, E., Martin, J. B., Ginn, B. and Smith, L. (2004), Conduit Properties and Karstification in the Unconfined Floridan Aquifer. Ground Water, 42: 338-346. doi: 10.1111/ j.1745-6584.2004.tb02682.

Shaw, J.E., and Trost, S.M., 1984, Hydrogeology of the Kissimmee Planning Area, South Florida Water Management District: South Florida Water Management District Technical Publication 84-1, 235 p., plus apps.

Sprinkle, C.L., 1989, Geochemistry of the Floridan aquifer system in Florida and in parts of Georgia, South Carolina, and Alabama: U.S. Geological Survey Professional Paper 1403-I, 105 p., 9 pls.

Vacher, H. L., and J. Mylroie (2002), Eogenetic karst from the perspective of an equivalent porous medium, Carbonates Evaporites, 17(2), 182-196.

Van Wagoner, J.C., Mitchum, R.M., Campion, K.M., and Rahmanian, V.D., 1990, Siliciclastic sequence stratigraphy in well logs, cores and outcrops; concepts for highresolution correlation of time and facies: American Association of Petroleum Geologists Methods in Exploration Series, no. 7, 55 p.

Van Wagoner, J.C., Posamentier, H.W., Mitchum, R.M., and others, 1988, An overview of the fundamentals of sequence stratigraphy and key definitions, in C. K. Wilgus and others, eds., Sea-level changes - An integrated approach: Society of Economic Paleontologists and Mineralogists Special Publication no. 42, p. 39-45.

Ward, W.C., Cunningham, K.J., Renken, R.A., Wacker, M.A., and Carlson, J.I., 2003, Sequence-stratigraphic analysis of the Regional Observation Monitoring Program (ROMP) 29A test corehole and its relation to carbonate porosity and regional transmissivity in the Floridan aquifer system, Highlands County, Florida: U.S. Geological Survey Open-File Report 03-201, 34 p., plus apps.

Weedman, S.D., Scott, T.M., Edwards, L.E., and others, 1995, Preliminary analysis of integrated stratigraphic data from the Phred \#1 corehole, Indian River County, Florida: U.S. Geological Survey Open-File Report 95-824, 63 p.

Wingard, G.L., Weedman, S.D., Scott, T.M., and others, 1994, Preliminary analysis of integrated stratigraphic data from the South Venice corehole, Sarasota County, Florida: U.S. Geological Survey Open File Report 95-3, 129 p. 

Appendix 1 


\section{Hydraulic Test Data}

Hydraulic test data, including data derived from aquifer performance tests, packer tests, step-drawdown, and specific capacity tests are listed in appendix table $1-6$. The references for the reports from which these test data were taken are provided in appendix table $1-2$. Values included in appendix table 1-6 include those for transmissivity, hydraulic conductivity, storativity, leakance, and specific capacity. Generally, data only for those tests conducted at about the depth of the uppermost permeable zone of the Lower Floridan aquifer or shallower in the Floridan aquifer system are included. Most of the packer tests were conducted during the drilling of deep injection well systems for the purpose of determining the degree of confinement of the tested interval, and pumping for these tests was at a constant rate for a short period of time, usually 3 to 4 hours. In contrast, the constant rate aquifer performance tests in completed wells were commonly pumped for much longer periods, such as 24 or 72 hours.

The transmissivity values reported in appendix table 1-6 for many of the tests are based on water-level data (drawdown) in production or monitoring wells collected during constant rate pumping or recovery. Methods of analysis for tests reported in appendix table 1-6 include those of Theis (1935) and Cooper and Jacob (1946) for "confined aquifers" and Hantush and Jacob (1955), Hantush (1960), Moench (1985), and Walton (1962) for "leaky confined aquifers." For some tests, no analytical method was reported, only that the analysis was made on drawdown or recovery data. Presumably, the method used for these tests was one for a confined aquifer. Horizontal hydraulic conductivity values were calculated from aquifer and packer tests using transmissivity results and the thicknesses of the open intervals tested.

Transmissivity is reported for some packer tests; however, these values are representative only of short intervals (commonly about 20 to 50 feet [ft] thick; appendix table 1-6). Some limitations on the reliability of transmissivity estimates determined from packer test data include partial penetration of an aquifer, low pumping rates, short pumping periods, the possibility of borehole wall skin effects due to incomplete development, and high friction losses as fluid flows up the small diameter of drill pipe compared to the diameter of casing in constructed wells. The conventional procedure for conducting packer tests is to pump the well prior to the test for a specified period or a period long enough to produce formation fluid of a constant salinity, although some wellbore damage may still remain after the development period. The packer test data were used to help identify contact boundaries of major permeable zones and semiconfining units and to provide insight to the magnitude of horizontal hydraulic conductivity.

The specific capacity of a well, determined by pumping the well at a constant rate until the water level stabilizes, is equal to the pumping rate divided by the feet of drawdown, and is reported in units of gallons per minute per foot (gal/min/ft). Transmissivity is proportional to specific capacity in large-diameter water-supply wells.

\section{References Cited in Appendix Table 1-2}

AECOM, 2010, Engineering report on the construction and testing of test production well TPW-1 for the Town of Davie: Prepared for the Town of Davie, p. 1-1 to 5-2, plus apps.

Bennett, M.W., Linton, P.F., and Rectenwald, E.E., 2001, Completion report for the exploratory well EXW-1, western Hillsboro basin site, Palm Beach County: South Florida Water Management District hydrogeologic investigation of the Floridan aquifer system, 34 p., 7 apps.

Black, Crow, and Eidsness Inc., 1974, Results of drilling and testing of monitoring and deep disposal wells at Margate, Florida: Engineering report prepared for the City of Margate Utilities Authority and LAH Associates, Limited, Fla., 31 p.

Camp, Dresser, and McKee, Inc., 1987, City of Plantation deep injection well-number 1: Final well completion report, p. 1-1 to 5-1, plus apps.

Camp, Dresser, and McKee, Inc., 1991a, City of Plantation Central District Water Treatment Facility R.O. reject disposal well - no. 1: Well completion report v. 1 .

Camp, Dresser, and McKee, Inc., 1991b, City of Plantation Regional Wastewater Treatment Plant effluent injection well - no. 2: Well completion report v. 1, p. 1-0 to 6-1.

Camp, Dresser, and McKee, Inc., 1993a, Floridan aquifer test/production well and monitor well: Completion report prepared for the City of Deerfield Beach, Florida, and South Florida Water Management District, 29 p.

Camp, Dresser, and McKee, Inc., 1993b, Wastewater Treatment Plant III well completion report dual zone monitor well 1A: Engineering report prepared for City of Sunrise, Fla., p. 1-0 to 5-2, plus apps.

Camp, Dresser, and McKee, Inc., 1993c, Wastewater Treatment Plant III well completion report dual zone monitor well 2: Engineering report prepared for City of Sunrise, Fla., p. 1-0 to 5-2, plus apps.

Camp, Dresser, and McKee, Inc., 1996, Engineering report supporting operational testing of IW-3 at Sunrise, Florida: Engineering report prepared for City of Sunrise, Fla., v. 1, p. $1-1$ to $8-3$, plus apps.

Camp, Dresser, and McKee, Inc., 2008, City of Deerfield Beach West Water Treatment Plant concentrate injection well system: Well completion report, v. 1, p. 1-1 to 7-1, plus apps.

Camp, Dresser, and McKee, Inc., 2010, City of Deerfield Beach West Water Treatment Plant Floridan aquifer well no. 2 final completion depth proposal: Memorandum to the South Floridan Water Management District, 6 p. 
CH2M HILL, 1984, Engineering report on drilling and testing of the deep injection and monitoring wells at the City of Margate Wastewater Treatment Plant: Prepared for the City of Margate Department of Utilities Margate, Florida, p. 1-1 to $4-4$, plus apps.

CH2M HILL, 1985, Engineering report on the drilling and testing of the City of Sunrise injection and monitoring wells: Prepared for the City of Sunrise, Broward County, Florida, p. $1-1$ to $5-1$, plus apps.

CH2M HILL, 1994, Report on the modification to monitor well MW-2: Prepared for the City of Margate Department of Environmental and Engineering Services, 7 p. 1-1 to $1-9$, attachments.

CH2M HILL, 1995, Rehabilitation of monitor well MW-1 and construction and testing of monitor well MW-2 and regional monitor well RMW-1 at the G.T. Lohmeyer Wastewater Treatment Plant: Engineering report prepared for the City of Fort Lauderdale, Broward County, Fla., p. 1-1 to 6-2, plus apps.

CH2M HILL, 1996, Construction and testing of monitor well MW-3 at the G.T. Lohmeyer Wastewater Treatment Plant: Engineering report prepared for the City of Fort Lauderdale, Broward County, Fla., p. 1-1 to 6-1, plus apps.

CH2M HILL, 1997, Construction and testing of the aquifer storage and recovery (ASR) system at the BCOES 2A Water Treatment Plant: Engineering report prepared for the Broward County Office of Environmental Services and Montgomery Watson, p. 1-1 to 6-3, 13 apps.

CH2M HILL, 1999, Construction and testing of injection well IW-4 at the City of Fort Lauderdale G.T. Lohmeyer Wastewater Treatment Plant: Engineering report prepared for the City of Fort Lauderdale, v. I, p. 1-1 to 6-1, plus apps.

Geraghty and Miller, Inc., 1984, Construction and testing of disposal wells 1, 2 and 3 at the George T. Lohmeyer Plant Fort Lauderdale, Florida: Report prepared for Broward County, v. I, 39 p., plus apps.

Geraghty and Miller, Inc., 1986, Construction and testing of an injection well at the Coral Springs Improvement District: Report prepared for Broward County, Fla., 30 p., plus apps.

Geraghty and Miller, Inc., 1990a, Construction and testing of injection wells \#1 and \#2 with associated deep monitor well \#1, Broward County North District Regional Wastewater Treatment Plant: Report prepared for James M. Montgomery, Consulting Engineers, Inc. in association with Hazen and Sawyer, P.C, Engineers, 30 p., plus apps.

Geraghty and Miller, Inc., 1990b, Construction and testing of injection well system \#2 at the Coral Springs Improvement District Wastewater Treatment Plant: Report prepared for the City of Coral Springs, Fla., 31 p., plus apps.
Geraghty and Miller, Inc., 1991, Construction and testing of injection wells \#3 and \#4 with associated deep monitor well \#2, Broward County North District Regional Wastewater Treatment Plant: Report prepared for James M. Montgomery, Consulting Engineers, Inc. in association with Hazen and Sawyer, P.C, Engineers, 32 p., plus apps.

Geraghty and Miller, Inc., 1995, Construction and testing of injection well \#2 at the Pembroke Pines Wastewater Treatment Plant: Report prepared for the City of Pembroke Pines, Fla., 23 p., plus apps.

Hazen and Sawyer, 1989, Completion report for the City of Hallandale Floridan aquifer test well: City of Hallandale, Fla.

Hazen and Sawyer, 1996, City of Miramar, Florida Utilities Department Wastewater Reclamation Facility injection well construction: Well construction report prepared for the technical advisory committee members, p. 1-1 to $4-4$, plus apps.

Hazen and Sawyer, P.C., 1999, North Regional Wastewater Treatment Plant monitor well 4 construction completion report: Prepared for Broward County Office of Environmental Services, p. 1-1 to 4-1, plus apps.

Hazen and Sawyer, P.C., 2000, Injection wells 5 and 6 construction completion report, North Regional Wastewater Treatment Plant: Prepared for Broward County Office of Environmental Services, p. 1-1 to 5-4, plus apps.

Hazen and Sawyer, 2001, Injection well no. 1 construction completion report - Water/Wastewater Treatment Plant: Prepared for Cooper City Utility Department, p. 1-1 to 5-5, plus apps.

Hazen and Sawyer, P.C., 2002a, Engineering well completion report concentrate disposal system: Prepared for the City of Pompano Beach in association with Water Technology Associates, Inc., p. 1-1 to 5-5, plus apps.

Hazen and Sawyer, P.C., 2002b, Underground Injection Control application, aquifer storage and recovery Class $\mathrm{V}$ injection well system at the Broward County 2A Water Treatment Plant Site: 4 p., plus apps.

Hazen and Sawyer, P.C., 2003, Engineering well completion report, Hollywood Southern Regional WWTP injection well effluent disposal system: Prepared for the City of Hollywood in association with Water Technologies Associates, Inc., p. 1-1 to 5-5, plus apps.

Hazen and Sawyer, P.C., 2006, Engineering well completion report, -Peele-Dixie Water Treatment Plant concentrate disposal well: Prepared for City of Fort Lauderdale, p. 1-1 to 5-5, plus apps.

Hazen and Sawyer, P.C., 2007, Engineering well completion report Hallandale Beach WTP concentrate disposal well: Prepared for the City of Hallandale Beach, p. 1-1 to 5-5, plus apps. 
Hazen and Sawyer, P.C., 2008, City of Plantation Regional Wastewater Treatment Plant engineering well completion report for dual zone monitoring well: Prepared for City of Plantation, p. 1-1 to 4-3, plus apps.

Hazen and Sawyer, P.C. and Geraghty and Miller, Inc., 1981, Construction and testing of the test injection well, City of Fort Lauderdale, Florida: Final report prepared for EPA project C-120474-220 city project 7089, 61 p., plus apps.

Lukasiewicz, John, 2003, Floridan aquifer system test well program, C-13 Canal, Oakland Park, Florida: South Florida Water Management District Technical Publication WS-16, 49 p., plus apps.

Malcolm Pirnie, Inc., 1990, City of Hollywood Water Treatment Plant Floridan aquifer test well: p. 1-1 to 7-1, plus apps.

Malcolm Pirnie, Inc., 2009, Technical memorandum detailing installation of test production wells F1 and F2: City of Miramar, Fla., p. 1-1 to 5-1, plus apps.

Metcalf and Eddy, Inc., and Missimer International, Inc., 2000, City of Plantation East Water Treatment Plant concentrate injection well no. 1 completion report, v. 1: Prepared for City of Plantation Utilities, Plantation, Fla., 81 p., plus apps.

Missimer and Assoc., Inc., 1992, Technical memorandum on the construction and testing of well F-2, City of Hollywood, Florida: Prepared for Metcalf \& Eddy, Inc., 32 p., plus apps.

Montgomery Watson, 1996, City of Miramar Western Water Treatment Plant Injection Well System, Injection Wells IW-1 and IW-2 and Monitor Well DZMW-1: Prepared for the City of Miramar, Florida, 2 reports plus apps.

Montgomery Watson, 1997, Modification of monitor well MW-1A at the Sawgrass Wastewater Treatment Plant: Report prepared for the City of Sunrise, Fla., plus apps.

Montgomery Watson, 1998a, Springtree Water Treatment Plant aquifer storage and recovery system well construction report: Prepared for the City of Sunrise, Florida, p. 1-1 to 5-1, 13 apps.

Montgomery Watson, 1998b, Fiveash Water Treatment Plant aquifer storage and recovery system well construction report: Prepared for the City of Fort Lauderdale, Florida, p. 1-1 to 6-1, 14 apps.

Montgomery Watson Americas, Inc., 1999, Sawgrass Water Treatment Plant concentrate disposal system report and appendix I: Prepared for City of Sunrise, Florida, p. E-2 to 6-14, plus apps.

Montgomery Watson Americas, Inc., 2007, Sawgrass Water Treatment Plant Floridan Blending Test Well: Sunrise Project no. 06-005 final report, 24 p., plus apps.
Palm Beach County Water Utilities Department, 2003, Eastern Hillsboro Canal Water Treatment Plant \#9 aquifer storage and recovery well: Well construction report and operational testing request, p. 1-1 to 4-1, 16 apps.

Post, Buckley, Schuh and Jernigan, Inc., 1987, Engineering report for deep test/injection well and deep monitor well: Prepared for the City of Pembroke Pines, Broward County, Fla., p. 1-1 to 11-4, plus apps.

\section{References Cited in Headnote to Appendix Table 1-6}

Cooper, H.H., Jr., and Jacob, C.E., 1946, A generalized graphical method for evaluating formation constants and summarizing well-field history: American Geophysical Union Transactions, v. 27, no. 4, p. 526-534.

Hantush, M.S., 1960, Modifications of the theory of leaky aquifers: Journal of Geophysical Research, v. 65, no. 11, p. 3713-3725.

Hantush, M.S., and Jacob, C.E., 1955, Nonsteady radial flow in an infinite leaky aquifer: American Geophysical Union Transactions, v. 36, no. 1, p. 95-100.

Moench, A.F., 1985, Transient flow to a large-diameter well in an aquifer with storative semiconfining layers: Water Resources Research, v. 21, no. 8, p. 1121-1131.

Theis, C.V., 1935, The relation between the lowering of the piezometric surface and the rate and duration of discharge of a well using ground-water storage: American Geophysical Union Transactions, v. 16, p. 519-524.

Walton, W.C., 1962, Selected analytical methods for well and aquifer evaluation: Illinois State Water Survey Bulletin no. $49,81 \mathrm{p}$. 
Manuscript approved January 6, 2014

Prepared by the Raleigh Publishing Service Center Mike Deacon, Editor

Kimberly Swidarski, Illustrations and layout

For more information about this publication, contact:

Director

U.S. Geological Survey

Florida Water Science Center

4446 Pet Lane, Suite 108

Lutz, FL 33559

(813) 498-5000

or visit our Web site at

http://fl.water.usgs.gov 


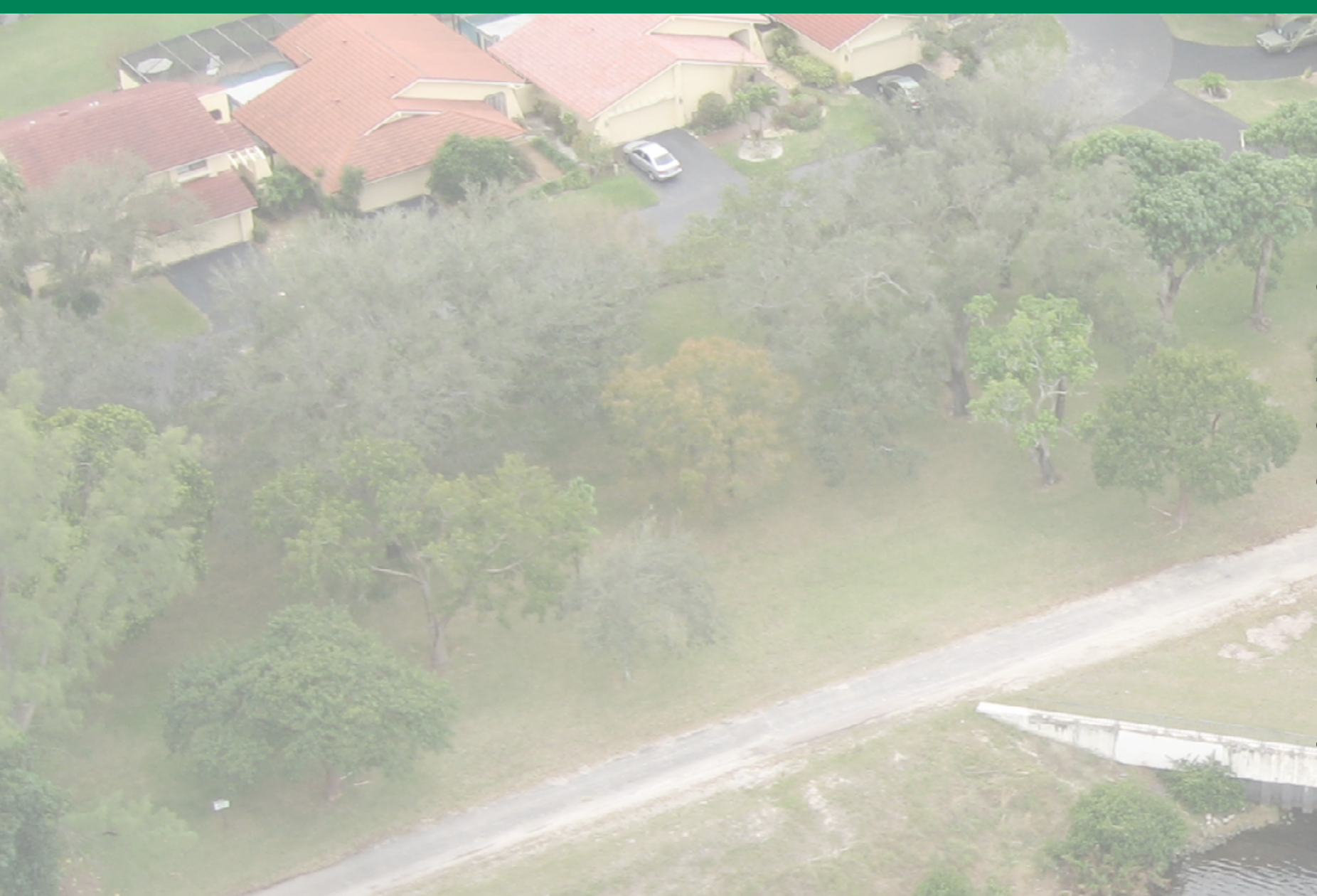

J
$\mathbb{D}$
$\infty$
$\infty$
0
0

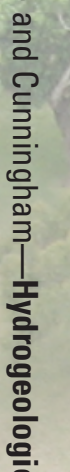

ते

今

윽

言

.

둥.

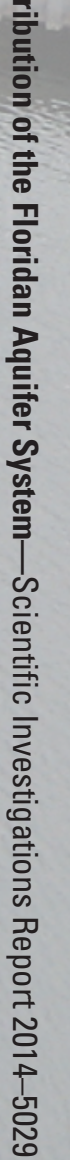

